\title{
Small Company Transfer of Technology to Developing Nations
}

\author{
by \\ Olawale Olufemi
}

\begin{abstract}
A thesis submitted to the Faculty of Graduate and Postdoctoral Affairs

in partial fulfillment of the requirements for the degree of
\end{abstract}

\author{
Master of Applied Science \\ in \\ Technology Innovation Management
}

Carleton University

Ottawa, Ontario

(C) 2012

Olufemi Olawale 
Library and Archives

Canada

Published Heritage

Branch

395 Wellington Street

Ottawa ON K1A ON4

Canada
Bibliothèque et

Archives Canada

Direction du

Patrimoine de l'édition

395 , rue Wellington

Ottawa ON K1A ON4

Canada
Your file Votre référence

ISBN: 978-0-494-93503-3

Our file Notre référence

ISBN: $978-0-494-93503-3$
NOTICE:

The author has granted a nonexclusive license allowing Library and Archives Canada to reproduce, publish, archive, preserve, conserve, communicate to the public by telecommunication or on the Internet, loan, distrbute and sell theses worldwide, for commercial or noncommercial purposes, in microform, paper, electronic and/or any other formats.

The author retains copyright ownership and moral rights in this thesis. Neither the thesis nor substantial extracts from it may be printed or otherwise reproduced without the author's permission.
AVIS:

L'auteur a accordé une licence non exclusive permettant à la Bibliothèque et Archives Canada de reproduire, publier, archiver, sauvegarder, conserver, transmettre au public par télécommunication ou par l'Internet, prêter, distribuer et vendre des thèses partout dans le monde, à des fins commerciales ou autres, sur support microforme, papier, électronique et/ou autres formats.

L'auteur conserve la propriété du droit d'auteur et des droits moraux qui protege cette thèse. $\mathrm{Ni}$ la thèse ni des extraits substantiels de celle-ci ne doivent être imprimés ou autrement reproduits sans son autorisation.
In compliance with the Canadian Privacy Act some supporting forms may have been removed from this thesis.

While these forms may be included in the document page count, their removal does not represent any loss of content from the thesis.
Conformément à la loi canadienne sur la protection de la vie privée, quelques formulaires secondaires ont été enlevés de cette thèse.

Bien que ces formulaires aient inclus dans la pagination, il n'y aura aucun contenu manquant. 


\section{Abstract}

This research examines the challenges faced by owners of small technology companies in Canada when entering markets in developing nations. The grounded theory approach was used to examine information provided by top managers of eight small technology companies operating in the province of Ontario. A coding system was used to analyse the data generated from the eight companies to identify factors influencing their market entry mode to developing nations. Five market characteristics were identifies as affecting entry mode: Market environment, Absorptive capacity, Limited resources, Type of technology and Market knowledge. Results provide a guide to small companies whose innovations face high competition in the domestic market when compared to a possible oligopolistic position in developing nations. 


\section{Acknowledgement}

My unparallel appreciation goes to God for his faithfulness and the gift of life to complete this program.

Thanks to my wife, Adebukanla Olawale, who had to acquire a new skill on how to keep quiet when critical time lines must be achieved. Tomisin and Sorefunmi, my two lovely children, had their share of my being in class again, thank you. The Overcomers' family, you had your bit of it too, thank you for your understanding. Finally, I like to appreciate the tireless effort of my supervisor Professor Tony Bailetti for his support, guidance and leadership. To my colleagues and classmates who have influenced my life in no small measure during theTI M program. 


\section{Table of Contents}

\section{Contents}

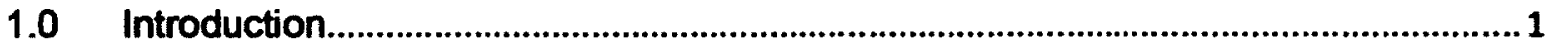

1.2 Deliverables...................................................................................................................

1.3 Contribution

1.4 Relevance ................................................................................................................

1.5 Organization .................................................................................................................

2.1 Definitions of Technology Transfer ................................................................................

2.2 Technology Transfer Literature Stream ...................................................................

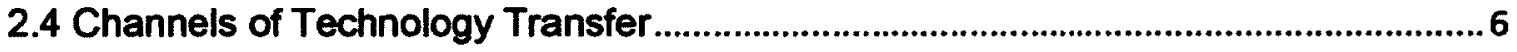

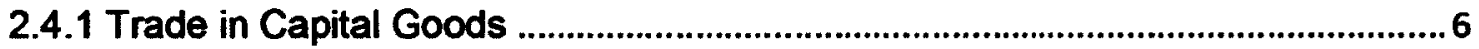

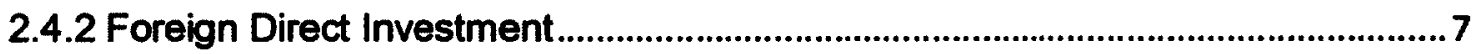

2.4.3 Licensing...............................................................................................................

2.4.4 Emigration, Immigration .........................................................................................

2.5 Entry Mode Theories..........................................................................................................9

2.5.1 Resource Base Theory and Entry Mode .................................................................

2.5.2 Transaction Cost Theory and Entry Mode.............................................................11

2.5.3 Internationalization Theory and Entry Mode .........................................................12

2.6 Choice of Market Entry Modes ..........................................................................................13

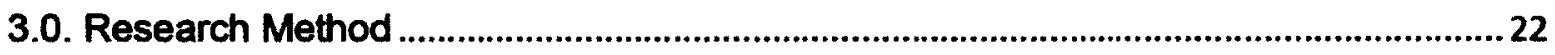

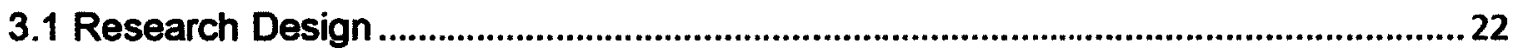

3.2 Unit of analysis ....................................................................................................22

3.2.2 Selecting the Sample.............................................................................................25

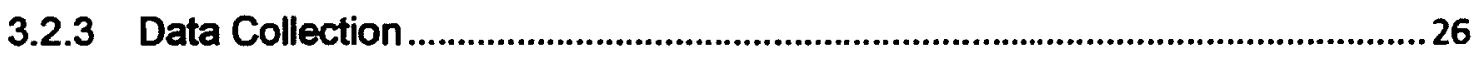

3.2.4 Entering the Field and Data Analysis...............................................................26

3.2.5 Build Models and Propositions...............................................................................29

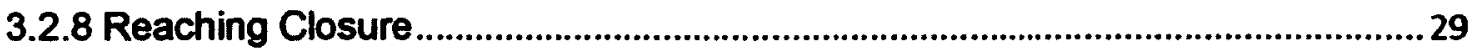

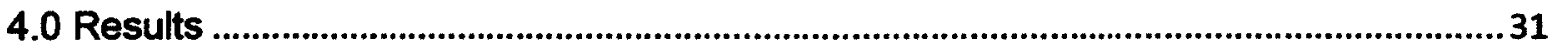

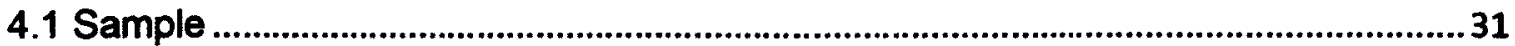




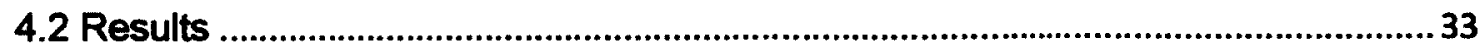

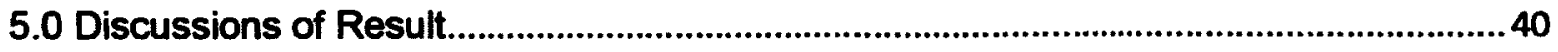

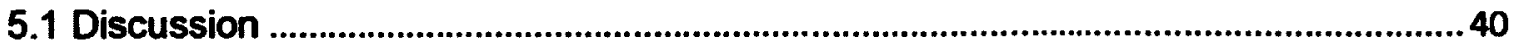

5.2 Market Characteristics- Entry Mode Model ................................................................. 48

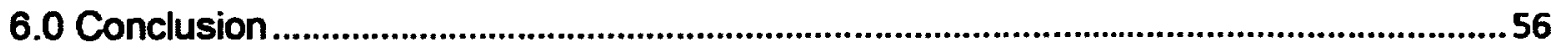

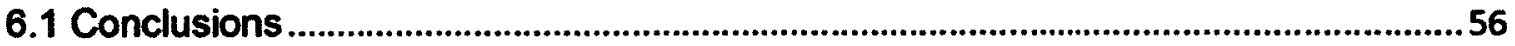

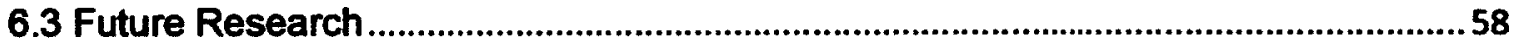

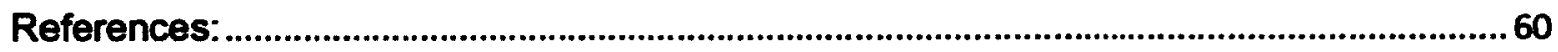

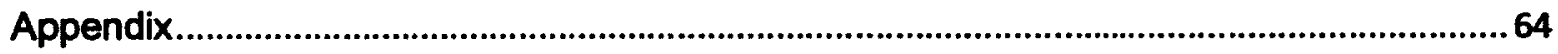




\section{Chapter 1}

\subsection{Introduction}

This research contributes insights relevant to managers of small technology companies that operate in Ontario, Canada who desire to enter markets in developing nations. The grounded theory approach was used to examine data provided by managers of eight small technology companies.

Small and medium sized companies have limited resources, and lack the knowledge required to sell in international markets (Knight, 2000; Hollenstein, 2005). However, interest to sell to developing nations is ever growing among small technology companies.

Research has examined how small and new firms use local and foreign intermediaries to sell their goods and services across national borders (Peng and York, 2001; Terjesen, Acs and O'Gorman, 2006). The bulk of this research, however, focuses on developed nations. Little is known about how small technology companies, particularly small Canadian companies, sell to developing nations.

This research answers two questions:

- What are the characteristics of the markets in developing nations that affect the way Canadian small companies enter them? 
- What are the entry modes of small companies to the developing nation in a limited resource environment?

\subsection{Definition of Terms}

For the purpose of this research a small company refers to a company with less than 50 and more than 5 employees.

A host market refers to the market in the developing nations.

\subsection{Deliverables}

This research provides three deliverables

1. The market characteristics that define the entry mode a small Canadian company selects to sell to a developing nation.

2. Model of the relationship between market characteristics and entry mode

3. Propositions defined by relationship between the market characteristics and the entry mode

\subsection{Contribution}

This research makes at least two contributions:

1. Models for choice of entry mode of small companies prospecting into developing nations are very scarce in literature. The research develops at least three models using the market characteristics of the developing nations, the elements that provide information to resolve the common challenges of small companies in accessing the host market. 
2. The models and proposition together define a circumstance based relationship. The combination is a decision tool for managers of small companies to make choice of entry into the developing nations. Replication of circumstance will inform choice of entry mode.

\subsection{Relevance}

This work is relevant to the following groups: researchers, entrepreneurs, and managers.

The researchers will be interested in this research because of existing scarcity of research work in this area of study. This study addressed entry mode of small companies into the developing nation which is a departure from what is commonly found in literature. Extant literature addresses small and medium enterprise together. Whereas they are expected to have unique challenges and issues in the market place and especially in the developing nations. This research attempts to fill this gap by its concentration on only small companies.

This research is of interest to entrepreneurs because they will be able to better assess the risks associated with their host market and choice of entry mode. The results derived from this research can be used by entrepreneurs to guide their business strategies and collaborative efforts with host market organizations and agents as the situation demands. The results also give them the opportunity to 
create "new space" navigating into new market to which entry choice decision model was not available.

The third group with interest in this research is management. Managers of small companies are daunted with lack of insight into the markets of developing nations. Our results provide the required Insights into the dynamics of the market in developing nation and it afford them a decision tool for market entry choice.

Managers of small company, saddle with design of profitable future in their bid for internationalization, will find the market characteristics useful in charting their effort towards the market in developing nations.

\subsection{Organization}

This thesis is organized into six chapters. Chapter 1 identifies this research's deliverables, contributions and relevance. Chapter 2 provides an overview of the literature. Chapter 3 discusses the method carried out to complete this research. Chapter 4 presents the results. Chapter 5 provides a discussion of the results. Chapter 6 provides the conclusions, limitations and identifies opportunities for future research. 


\section{Chapter 2}

\subsection{Literature Review}

Chapter 2 provides the literature review and it is organized into seven sections.

Section 2.1 provides definitions of technology transfer. Section 2.2 examines the technology transfer literature. Section 2.3 discussed technology transfer models and section 2.4 examines the literature on technology transfer channels. Section 2.5 reviews the literature on entry modes. Section 2.6 reviews the literature on choice of market entry mode. Section 2.7 provides the lessons learned.

\subsection{Definitions of Technology Transfer}

The complexity of the technology transfer process makes it difficult to provide a simple definition (Robinson R,1988; Spivey, W., Munson, J., Nelson, M., Dietrich, G., 1997).

Table1 identifies the definitions of technology transfer found in the literature. For each definition, Table 1 provides the reference to the source of the definition, the situation where the definition best applies, and the mechanisms used to transfer technology, and the nature of the outcome of the technology transfer. 


\begin{tabular}{|c|c|c|c|c|}
\hline Source & Definition & Applicable & Mechanism & Outcome \\
\hline Seurat (1979) & $\begin{array}{l}\text { The capacity to store and } \\
\text { transmit to people the } \\
\text { accumulated experience of } \\
\text { others }\end{array}$ & $\begin{array}{l}\text { Provision of training sessions for } \\
\text { the purpose of transferring } \\
\text { underlining knowledge of a } \\
\text { technology }\end{array}$ & $\begin{array}{l}\text { Foreign training } \\
\text { and exchange } \\
\text { program }\end{array}$ & $\begin{array}{l}\text { Successful } \\
\text { transfer is } \\
\text { subjective }\end{array}$ \\
\hline Robinson (1988) & $\begin{array}{l}\text { Something consisting of an } \\
\text { "embodied element" and a } \\
\text { "disembodied element" }\end{array}$ & $\begin{array}{l}\text { It consists of transfer of physical } \\
\text { equipment designed to perform } \\
\text { a specific function. Disembodied } \\
\text { includes blueprints, human } \\
\text { skills, knowledge and } \\
\text { accumulated experience. }\end{array}$ & $\begin{array}{l}\text { Direct } \\
\text { exportation of } \\
\text { equipment and } \\
\text { trade in } \\
\text { intellectual } \\
\text { properties }\end{array}$ & $\begin{array}{l}\text { Value of } \\
\text { disembodied } \\
\text { form is } \\
\text { usually } \\
\text { difficult to } \\
\text { quantify }\end{array}$ \\
\hline $\begin{array}{l}\text { Souder (1990), } \\
\text { Ramanathan } \\
(1994)\end{array}$ & $\begin{array}{l}\text { It is the process of movement of } \\
\text { technology from one entity to } \\
\text { another }\end{array}$ & $\begin{array}{l}\text { Downloading of content from } \\
\text { web page into a local medium } \\
\text { to facilitate use. }\end{array}$ & $\begin{array}{l}\text { Laboratory } \\
\text { prototype to full } \\
\text { scale design }\end{array}$ & \\
\hline Philips (2002). & $\begin{array}{l}\text { Movement of equipment or } \\
\text { knowledge from developed to } \\
\text { developing countries, or from } \\
\text { one application domain to } \\
\text { another }\end{array}$ & $\begin{array}{l}\text { Inter boundary movement of } \\
\text { technology base item. }\end{array}$ & $\begin{array}{l}\text { Foreign training } \\
\text { and exchange } \\
\text { program }\end{array}$ & $\begin{array}{l}\text { Most } \\
\text { commonly } \\
\text { referenced } \\
\text { as } \\
\text { technology } \\
\text { transfer } \\
\end{array}$ \\
\hline $\begin{array}{l}\text { Asrat Tessema } \\
\text { and Alahassane } \\
\text { Diallo (2010) }\end{array}$ & $\begin{array}{l}\text { It entails some form of } \\
\text { knowledge flow in the form of } \\
\text { product, process and } \\
\text { management across national } \\
\text { boundaries. }\end{array}$ & & $\begin{array}{l}\text { Foreign direct } \\
\text { investment, } \\
\text { trade in goods, } \\
\text { training } \\
\text { programs, } \\
\text { blueprints etc }\end{array}$ & $\begin{array}{l}\text { This } \\
\text { definition } \\
\text { encompass } \\
\text { most forms } \\
\text { of } \\
\text { technology } \\
\text { transfer }\end{array}$ \\
\hline
\end{tabular}

Table 1: Definitions of Technology Transfer

\subsection{Technology Transfer Literature Stream}

Literatures on technology transfer centers on the activities of multinational

organizations whilst small and medium enterprises are treated together. Very few

materials are available on the technology transfer activities of small companies. 
The main focus of technology transfer is to improve the competitive advantage of transferor through the enhancement of customer value. One of the major expectations of firms and their partners collaborating in technology transfer is substantial increase in financial and strategic benefits, through the improvement of competitive advantage (Ramanathan, 2001).

Small and medium enterprises (SMEs) use technology transfer as a means to meet the challenges posed by globalisation Mayer and Blaas (2002).

Innovative technology is converted to economic value and sold in different modes. Technology is incorporated into new products and services that are sold in the market or the knowledge behind the technology, disembodied from physical artefacts, are sold through one of several contractual forms, such as licensing agreements, joint ventures, and patent sales (Lichtenthaler 2005). Innovative firms internalize their technology to maximize value (Chandler 1990). In the last decade, more companies are commercializing their technologies externally (Arora and Gambardella 2010). Revenues from technology outlicensing have skyrocketed in the last decades (Athreye and Cantwell 2007) and the value of global technology transactions has grown from $\$ 35-\$ 50$ billion in the late 1990 s to an estimated $\$ 100$ billion in recent years (Arora and Gambardella 2010). 


\subsubsection{Challenges and issues of Technology Transfer}

Challenges and issues are associated with technology transfer effort of small and medium enterprises. Godkin (1988) produced a comprehensive list of problem areas associated with technology transfer. Jagoda (2007) and Ramanathan (2007) added problems that confront small and medium scale enterprise when planning and managing technology transfer. The various challenges and problems were classified into three categories namely, technology transfer process issues, corporate capability issues, and operating environment. Small and medium productive entities were identified as most affected by these problems Ramanathan (2007). The details of the technology transfer problems are shown under the three main categories in table 2 below. 


\begin{tabular}{|c|c|c|}
\hline Technology Transfer Process Issues & $\begin{array}{c}\text { Corporate Capability } \\
\text { Issues }\end{array}$ & $\begin{array}{l}\text { Operating Environment and } \\
\text { National Innovation System }\end{array}$ \\
\hline $\begin{array}{l}\text { 1. Problems during the technology justification and selection stage } \\
\text { - Wrong selection of technology based on misjudgements when preparing } \\
\text { a business case for a technology transfer project } \\
\text { - The cost of buying, installing, operating, and maintaining the technology } \\
\text { is too high } \\
\text { - The technology selected is too complex for easy understanding and } \\
\text { assimilation of the transferee } \\
\text { - The technology needs considerable adaptation to suit local conditions } \\
\text { - Obsolescence of technology while the transfer is in progress } \\
\text { 2. Problems during the planning stage } \\
\text { - Transferor (seller) underestimates the problems in transferring the } \\
\text { technology to a developing country setting } \\
\text { - Transferor does not fully understand transferee needs } \\
\text { - Transferee managers are not involved in the planning which is carried out } \\
\text { only by the transferor } \\
\text { - Too much attention is paid to the hardware to be purchased and not } \\
\text { enough attention is paid to skills } \\
\text { and information acquisition } \\
\text { - Overestimation of the technological capabilities of the transferee by the } \\
\text { transferor thereby leading to unrealistic expectations on how well the } \\
\text { transferee can meet target dates } \\
\text { - Poor market demand forecasting by the transferee of the outputs to be } \\
\text { produced by using the transferred technology } \\
\text { - The objectives of the transferor and transferee are not compatible } \\
\text { - Mechanisms chosen for implementing the transfer are not appropriate }\end{array}$ & $\begin{array}{l}\text { 1. Problems due to inadequate } \\
\text { skills } \\
\text { - Inability of the transferee to } \\
\text { attract the required skills due to } \\
\text { financial and industrial restrictions } \\
\text { - Lack of experience of the } \\
\text { transferee's workforce and } \\
\text { absence of required skills at the } \\
\text { industry level } \\
\text { - Lack of training of transferee } \\
\text { personnel } \\
\text { - Absence of incentive systems at } \\
\text { the transferee firm for learning and } \\
\text { assimilating new technologies } \\
\text { - Language barriers that inhibit } \\
\text { effective communication between } \\
\text { transferor and transferee } \\
\text { personnel and restrict effective } \\
\text { transmission and assimilation of } \\
\text { relevant information } \\
\text { 2. Problems due to ineffective } \\
\text { management } \\
\text { - Lack of visible and committed top } \\
\text { management support for the } \\
\text { project } \\
\text { - Lack of top management }\end{array}$ & $\begin{array}{l}\text { - Shrinking of local markets due to adverse } \\
\text { changes in the economic levels of the country } \\
\text { - Poor physical infrastructure } \\
\text { - Inadequate supportive institutional } \\
\text { infrastructure to provide support in terms of } \\
\text { finance, information, skill development, and } \\
\text { technology brokering } \\
\text { - Inadequate mechanisms for intellectual } \\
\text { property protection } \\
\text { - Lack of local suppliers who can deliver quality } \\
\text { supplies and lack of policies to develop such } \\
\text { suppliers } \\
\text { - High dependency on foreign suppliers and } \\
\text { imports } \\
\text { - Lack of good education and training institutions } \\
\text { to upgrade skills } \\
\text { - Ineffective legislation and incentives such as tax } \\
\text { holidays, tariff adjustments, and industry parks to } \\
\text { promote technology transfer } \\
\text { - Bureaucratic delays at various levels of } \\
\text { government in obtaining approvals and } \\
\text { clearances for finalizing technology transfer } \\
\text { agreements } \\
\text { - Ineffective and sometimes excessive } \\
\text { government intervention and regulation } \\
\text { - Foreign exchange restrictions } \\
\text { - Inability of new ventures to compete with }\end{array}$ \\
\hline
\end{tabular}




\begin{tabular}{|c|c|c|}
\hline $\begin{array}{l}\text { 3. Problems during negotiations } \\
\text { - Differences in negotiation approaches and strategies } \\
\text { - Lack of trust between the transferor and transferee } \\
\text { - Goal incompatibility during negotiations } \\
\text { - Inability to reach agreements on pricing, product, and marketing } \\
\text { strategies } \\
\text { - Both parties try to achieve results in an unrealistically short period of } \\
\text { time } \\
\text { 4. Problems during technology transfer implementation } \\
\text { - Shortage of experienced technology transfer managers } \\
\text { - Lack of trust in transferor developed systems by the transferee } \\
\text { - Inability to achieve quality targets } \\
\text { - Delay in obtaining supplementary materials, needed for quick } \\
\text { implementation, from the local environment } \\
\text { - High cost and poor quality of locally available materials needed to } \\
\text { implement the technology transferred } \\
\text { - Inadequate tracking of the technology during implementation } \\
\text { - Cost overrun due to poor implementation }\end{array}$ & $\begin{array}{l}\text { guidance to decide the type of the } \\
\text { technology to be acquired, } \\
\text { remuneration, incentives } \\
\text { associated with the transfer, and } \\
\text { the control of the flow of } \\
\text { information. } \\
\text { - Differences in working methods } \\
\text { and practices between the } \\
\text { transferor and transferee } \\
\text { managers } \\
\text {-Individual or organizational } \\
\text { competition for the ownership of } \\
\text { the technologies and the presence } \\
\text { of the "not-invented-here" } \\
\text { syndrome } \\
\text { - Failure of top management to } \\
\text { identify transferee and transferor } \\
\text { personnel who would work closely } \\
\text { form project initiation through to } \\
\text { full implementation }\end{array}$ & $\begin{array}{l}\text { former monopolies, often owned by government } \\
\text { - Uncertain tax environments }\end{array}$ \\
\hline Technology Transfer Process Issues & $\begin{array}{c}\text { Corporate Capability } \\
\text { Issues }\end{array}$ & $\begin{array}{l}\text { Operating Environment and } \\
\text { National Innovation System }\end{array}$ \\
\hline
\end{tabular}

Table 2: Problems of technology transfer 
These problems continue to affect SMEs and even large fims in many developing nations. While a SME may not be able to handle problems related to the operating environment and the new innovation issues (NIS), it should nevertheless guard against these while working with the relevant Business Associations and Chambers of Commerce to lobby governments to rectify these Ramanathan (2007).

\subsection{Some Technology Transfer Models}

Literatures have proposed two types of model namely qualitative and quantitative. "Qualitative models often have as their objective the delineation of activities involved in managing technology transfer and the elicitation of factors and issues that can influence the success and/or effectiveness of technology transfer. Quantitative models, on the other hand, aim at quantifying parameters of significance in technology transfer and analyzing them with a view towards minimizing goal incompatibility between the transferors and transferees of technology." Jagoda (2007). This review is focused on the qualitative models.

2.3.1 Bar-Zakay Model: Bar-Zakay (1971) developed a rather comprehensive technology transfer model based on a project management approach. Technology transfer process was divided into the Search, Adaptation, Implementation, and Maintenance stages. Project management processes (of activities, milestones, and decision points (go or no-go)) were identified in each 
of these stages. Activities of the transferor and transferee were specified to different degree of details and the importance of both the transferor and transferee acquiring skills to undertake technological forecasting, long-range planning, and gathering of project-related intelligence is emphasized.

The Bar-Zakay model emphasizes the need for a comprehensive examination of the entire technology transfer process from "search" right through to "postimplementation" activities. It is a process approach that enables milestones and decision points to strengthen activities, correct mistakes or even terminate the project at any point in time Ramanathan (2007)

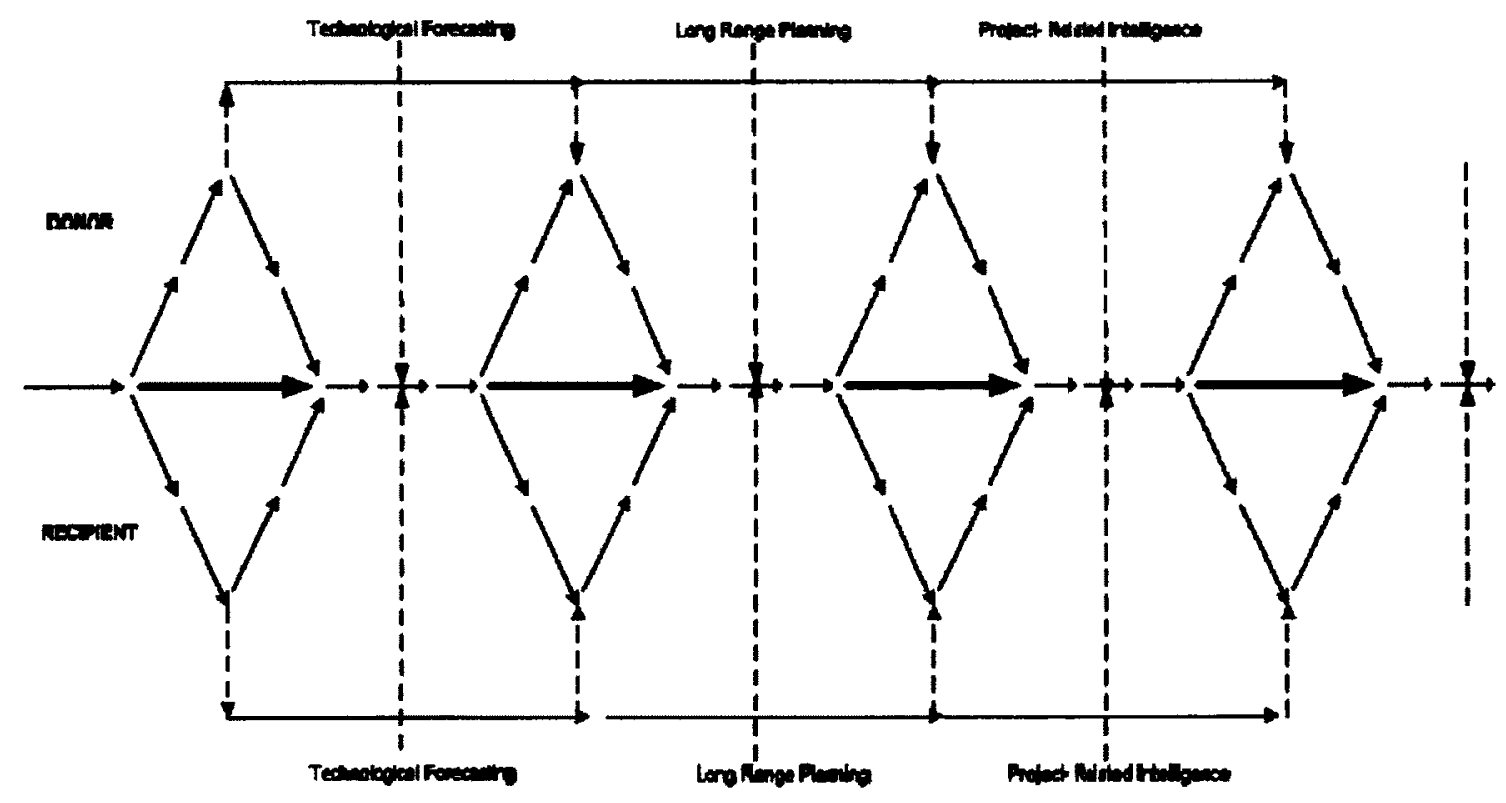

Figure 1: Bar-Zakay Model Source: Jagoda (2007)

2.3.2 Dahlman and Westphal Model: Dahlman and Westphal (1981) designed a model for rapidly industrializing countries. A nine stage process model 
proposed with the following activities: Perform pre-investment feasibility for viability, identify technology, perform basic detailed engineering study, selection of suppliers for equipment and subcontracting services, prepare and execute a training and education plan, construct the plant commence operations and develop trouble-shooting skills to solve design and operational problems as they arise.

2.3.3 Schlie, Radnor, and Wad Model: Schlie et al. (1987) propose a simple, generic model that identifies elements that can influence the planning, implementation, and eventual success of any technology transfer project. The elements are the transferor, the transferee, the technology that is being transferred, transfer mechanism (mode), transferor and transferee environment. The environment in this context is the immediate set of conditions, in which the transferor/transferee operates. Attributes of the transferor environment that can influence the effectiveness of the transfer process include, among others, economic status, business orientation (inward versus outward), stability, attitude and commitment to the transfer project, and operating policies. The transferee environment includes attributes that can influence the absorptive capacity of the transferee such as physical and organizational infrastructure, skills availability, attitude and commitment to the transfer project, technological status, business orientation (inward versus outward), economic status, and stability Jagoda, Ramanatha (2007)

The last element in the model is the greater environment. This describes the 
environment that is common to both the transferor and the transferee. Layers such as sub-regional, regional, and global could be identified in this environment. Factors in the greater environment such as political relationships between countries, exchange rates, investment climates, trade negotiations, balance of trade, relative technological levels, and the status of intellectual property protection regimes could have a great influence on the success of a technology transfer project Jagoda (2007)

2.3.4 Chantramonklasri Model: Chantramonklasri (1990) improved the Dahlman and Westphal (1981) Model whilst proposing a five phase model.

The five phases of the model are: Perform a pre-investment and feasibility study, develop engineering specifications and design based on the feasibility study, commence capital goods production, start-up and commence commercial production.

Ramanathan (2007) observed that Chantramonklasri (1990) model could only be valid in large, technologically advanced countries such as China and India; it may not be useful in other smaller developing countries.

2.3.5 Reddy and Zhao Model: Reddy and Zhao (1990), in a model similar to that of Schlie et al. (1987) state that any international technology transfer project should examine three main components, namely the home-country and hostcountry component, and transaction component. 
The home-country (transferor) component involves an examination of issues such as home-country government policies on technology transfer (restrictions etc.), the role and strategy of transferring firms from a foreign direct investment point of view, the nature and importance of technology to be transferred, and the firm's global R\&D investment strategy.

The host country (transferee) component involves issues such as host-country government policies related to foreign investment and technology transfer, the relative suitability of the technology being considered for transfer, the technological capability of the transferee and the scope for upgrading, mechanisms of transfer being considered, and the scope for assimilation of the transferred technology.

The transaction component consists of important business issues such as the pricing of technology, intellectual property protection, payment modalities, potential conflicts, and measures for ensuring effective transfer.

Literature recognizes that no single model can capture all the important considerations raised in most technology transfer model. An eclectic model that presents all this body of knowledge in a process-oriented approach would be very useful to managers of technology transfer project Ramanathan (2007) 


\subsection{Channels of Technology Transfer}

This review identified four technology transfer channels: i) Trade in capital goods and services, ii) foreign direct investment, iii) direct trade in knowledge (contractual arrangements such as licensing), and iv) migration (of scientists and technical personnel to developing nations).

\subsubsection{Trade in Capital Goods}

Entrepreneurs conduct R\&D to profit from monopoly power that results from innovation (Teece 1988). Growth may be sustained through the creation of new products that expands the knowledge stock and lowers the cost of innovation. Alternatively, consumers may be willing to pay a premium for higher quality products. As new products result from new ideas, international trade can help sell embodied knowledge beyond the borders of the local market (Hoekman et al., 2002).

Trade contributes to international technology transfer by providing local firms access to new technologies embodied in imported machinery and equipment. In their analysis of access to technologies through Imports, Coe and Helpman (1995) and Coe, Helpman, and Hoffmaister (1997) find that foreign knowledge (R\&D) embodied in traded goods has a statistically significant positive impact on aggregate performance index of importing countries. It creates opportunities for reverse engineering of products developed abroad. Trades create incentives to adopt and improve technologies through exporting opportunities. Firms learn 
about technologies by exporting to knowledgeable buyers, who share product designs and production techniques with them.

\subsubsection{Foreign Direct Investment}

A second channel is the foreign direct investment or the pursuit of project specific joint ventures. Multinational enterprises used their link to their subsidiaries to transfer technology information (to ensure global standard in production). Foreign direct investment (FDI) is an important direct source of technology and knowledge. Almost all studies show that firms with foreign capital and linkage perform better than indigenous firms, even after controlling for the fact that foreign investors generally select plants that are more productive in the first place.

Investments by multinational enterprises may provide developing country affiliates and partners with access to more efficient foreign technologies, as noted by Kamal Saggi (1996).

FDI may provide developing countries with more efficient foreign technologies and result in technological spill over and greater competition. In addition to demonstration effects (imitation) case studies suggest that substantial technology diffusion occurs due to FDI (Blomstrom and Kokko, 1997).

\subsubsection{Licensing}

Licensing is an important source of international technology transfer for developing countries Correa (2003). The host firm purchase the production or 
distribution rights and its associated technical information and know-how. The general determinants of decisions on where to license are similar to those involve in FDI. Market size, anticipated growth, proximity, the stock of human capital, the ability to repatriate licensing rents, and the investment climate all affects licensing flows. Another factor is the confidence of licensor firms that proprietary technologies will not leak into the host economy. This method is open to the transfer of lagging technologies (Maskus, 2000, Saggi, 1996). Successful transfer typically requires capacity to learn and investments to apply technologies into production processes. This explains why countries with substantial engineering skills and R\&D programs for adaptation and learning are greater recipients of licensing flows than others (Yang and Maskus, 2001). Direct trade in knowledge are mostly supported by policies that protect intellectual property.

\subsubsection{Emigration, Immigration}

Labour turnover is equally a channel for international technology transfer (ITT).

Technology may also be transferred through the temporary migration of students, scientists, managerial and technical personnel to universities, laboratories and conferences located mainly in the developed economies. In-depth training in science and technology may be gained this way and can be a long lasting form of international technology transfer. Studies have shown that intra-national labour turnover from multinationals to local firms is limited (Gershenberg, 1987), while others find the opposite (Rhee, 1990). An explanation is that in countries where local firms are not too far behind multinationals in technical terms, labour turnover is more likely. Thus, the ability of local firms to absorb new technologies 
is a determinant of whether labour turnover is a means of technology diffusion or transfer. The challenge of the developing nations in benefiting from this channel is in their ability to facilitate temporary movement abroad and to encourage retumees to undertake local research and business development.

\subsection{Entry Mode Theories}

The entry mode literature has witnessed the emergence of some key entry mode choice theories over the last four decades Varinder M. Sharma \& M. Krishna Erramilli (2004). It mostly explains the entry mode of multinationals and medium scales firms. Three of such theories were reviewed.

Entry mode is defined as a structural arrangement that allows a firm to implement its product market strategy in a host country either by carrying out only the marketing operations (i.e., via export modes), or both production and marketing operations there by itself or in partnership with others (contractual modes, joint ventures, wholly owned operations) Varinder M. Sharma \& M. Krishna Erramilli (2004)

\subsubsection{Resource Base Theory and Entry Mode}

The resource base theory proposes a firm can gain sustainable competitive advantage through the accumulation of strategic resources (Barney 1991). These include physical, human and organizational capital resources. Total organization's capabilities and disabilities evolve over time and it is entrenched in their resources; then it shifts to their processes and values. Their resource composition determines their capability as a whole. (Christensen 1997). Firm- 
specific resources in the production and marketing areas help them develop a competitive advantage. Strategic deployment of such resources within the knowledge of the market environment in the host country defines the entry mode.

Table 2.1 below shows the combination of possible entry mode as informed from the perspective of the resource base theory. The entry modes entail two key strategic decisions: the location of production and/or marketing activities (within or outside the host country) and their ownership (full ownership, partial, or none).

\begin{tabular}{|c|c|c|c|}
\hline \multirow{3}{*}{ 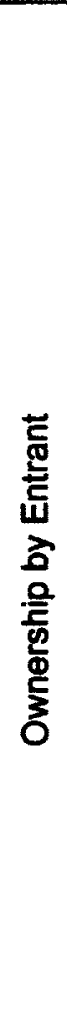 } & Full & $\begin{array}{l}\text { Direct Export via } \\
\text { Company Owned } \\
\text { Channel (Sales } \\
\text { Subsidiary, } \\
\text { Direct-to- } \\
\text { Customers }\end{array}$ & $\begin{array}{l}\text { Wholly Owned } \\
\text { Subsidiary } \\
\text { (Greenfield or } \\
\text { Acquisition) }\end{array}$ \\
\hline & Partial & & $\begin{array}{l}\text { Joint Ventures in } \\
\text { Production or } \\
\text { Marketing (majority. } \\
50-50 \text {, or minority) }\end{array}$ \\
\hline & None & $\begin{array}{l}\text { Indirect Exporting, } \\
\text { Direct Exporting via } \\
\text { Host Country } \\
\text { Intermediaries }\end{array}$ & $\begin{array}{l}\text { Contractual modes } \\
\text { (Licensing, } \\
\text { Franchising) }\end{array}$ \\
\hline
\end{tabular}

Table 3: ENTRY MODES: CLASSIFICATION BY LOCATION AND OWNERSHIP CHARACTERISTICS Varinder M. Sharma \& M. Krishna Erramilli (2004) 


\subsubsection{Transaction Cost Theory and Entry Mode}

The focal point of transaction cost theory is the reduction in transaction cost and control of the market share. Company tend to exploit a firm-specific asset in a foreign market and when this exploitation has to be done in that market due to localisation factors (e.g trade barriers, high transportation costs or other countryspecific factors), the company often do this by investing abroad in their own facilities rather than through, for example a license. The more intangible the firmspecific asset is, the stronger this tendency will be.

The transaction cost theory explains the choice between the indirect and direct exporting modes based upon the specificity of the company asset that is being exported. Under the transaction costs theory, a firm will export directly via a company owned channel where the asset to be deployed is highly unique to the company and the cost of controlling the product in the market is high. The theory predict an indirect exporting via host country intermediary where cost of control in the market is low Sharma and M. Krishna Erramilli (2004)

According to the transaction cost view, the firm's ownership decision is guided by the minimization of the transaction costs (e.g., cost of development, monitoring, and enforcement of contract). The full ownership mode would be preferred if the transaction costs of an exchange are high, otherwise the market intermediary option would be preferred. Erramilli and Rao (1993) 


\subsubsection{Internationalization Theory and Entry Mode}

The internationalization theory uses the concepts of market commitment and market uncertainty to explain an establishment chain comprising four modes: indirect exporting, direct exporting via host country intermediaries, sales subsidiary, and wholly owned subsidiary. It covers both the location and ownership dimensions in entry mode analysis.

In the direct exporting mode, a firm is directly involved in a host country marketing operations pertaining to its products either by itself or through local intermediaries. If it chooses the first route, the entry mode is referred to as Direct Exporting via Company Owned Channel, for the second route, the entry mode is described as Direct Exporting via Host Country Intermediary. Consistent with its incremental approach, the internationalization theory predicts that firms move from indirect exporting to direct exporting modes as they accumulate international experience and market knowledge. It also predicts that the choice of exporting via host country intermediary mode precedes the exporting via company owned channel mode Johanson and Vahlne (1990).

Internationalization theory posit that the firm enters into a host country through indirect exporting and gradually switches over to exporting through independent representatives, sales subsidiary, and wholly owned subsidiary mode with the reduction of its market uncertainty. 


\subsection{Choice of Market Entry Modes}

Entry decision is a critical step in internationalization. A critical aspect of importance to firm's success or failure is the entry mode choices. The selection of an appropriate entry mode strategy is crucial and it affects the overall outcome of firm's internationalization endeavour (Woodcock, Beamish and Makino, 1994).

Over the years, different types of foreign entry modes have been identified and these includes low control non-equity modes (exporting, licensing/contractual agreement and R\&D contracts, franchising, strategic alliance) and high control equity modes:(joint venture and wholly owned subsidiary (Brassinton and Pettitt, 2000; Peinado, Barber and Hébert, 2007). Each of these entry modes is associated with varying degree of control, risks and resource commitment (Hill, Hwang and Kim 1990).

\subsubsection{Low control non-equity modes}

(a) Exporting is a well established and a well known form of operating in foreign markets. This may be direct or indirect. Direct exports involve choosing an agent or a distributor, or establishing a branch or subsidiary to represent the firm in the foreign market-place. The indirect export is an arrangement whereby the firm delegates varying degrees of foreign sales and/or distribution responsibility to a third party. The third party may be an independent exporting buyer or an export management company Cateora and Graham, (2002). 
(b) Licensing / Contractual Agreement: A licensing / contractual agreement is an arrangement whereby a licensor grants the rights to intangible property to another entity (the licensee) for a specified time period, and in retum, the licensor receives a royalty fee from the licensee. Intangible property includes patents, inventions, formulas, processes, designs, copyrights, and trademarks.

The advantage of licensing is that it has no major cost implication to the transferor and risks are minimized. Control is practically eliminated (Czinkota, 1996; Rajan and Pangarkar, 2000).

(c) R\&D Contracts: Firms uses R\&D contracts to transfer the right to use its individual property (patents, technical knowledge or trademarks) to a foreign entity. It can use same contracts or its variance to authorise the assembly of its products by manufacturers established in a foreign market, while still maintaining the responsibility for marketing and distributing its products. The advantage of this arrangement is minimum investment and early market entry (Luo, 2006).

(d) Strategic Alliance is a mutually beneficial long-term formal relationship formed between two or more parties to pursue a set of agreed upon goals or to meet a critical business need while remaining independent organizations. It is a form of synergy that allows more than two organizations to cooperate in a business activity where each brings different strengths and capabilities to the arrangement (Czinkota, 1996; Pan, Tse and Au, 1997). 


\subsubsection{High control equity modes}

(a) Joint Ventures: This is an establishment of a firm that is jointly owned by two or more otherwise independent firms. The local firm brings the advantage of his knowledge of the local market to the table (i.e host country's competitive conditions, culture, language, political systems, and business systems). The foreign firm will have to bear the associated risks of giving control of technology to its partner (Czinkota, 1996; Rajan and Pangarkar, 2000; Chung and Enderwick, 2001). Joint ventures can be equity or non equity based and it allows parties to seek technical service arrangements, franchise and brand use agreements, management contracts or rental agreements, or one-time contracts, for example via construction projects.

(b) Wholly owned subsidiary: In this arrangement the firm owns 100 percent of the stock. The firm may establish a totally new company or acquire an existing company in the target market and use that firm to promote its products in the country's market. This entry mode affords total control of operations and it allows for the propagation of firms strategic goals. But establishing a wholly owned subsidiary is generally the most costly method of serving a foreign market (Rajan and Pangarkar, 2000; Chung and Enderwick, 2001).

Each of the entry modes can be associated with varying degree of cost and benefits. Sanjeev and Sridhar (1998) identified four entry modes and their cost and benefits. 
Firstly, the exporting mode is a low resource (investment) and consequently low risk/return alternative. This mode, while providing a firm with operational control, lacks in providing marketing control that may be essential for market-seeking firms.

Secondly, the sole venture mode is a high investment and consequently high risk or return alternative that also provides a high degree of control to the investing firm.

Thirdly, the joint venture mode involves relatively lower investment and hence provides risk, return, and control commensurate with the extent of equity participation by the investing firm.

Finally, the licensing mode is a low investment, low risk/return alternative which provides the least control to the licensing firm.

Pan and Tse (2000) outlined the choice of entry modes as a multi-level hierarchy as shown in Figure 2 below. They viewed market entry choice decision as a hierarchical process that starts with an initial decision between non-equity and equity-based modes (Chen, 2007). However, managers consider only a few critical factors at each level of the hierarchy, whilst those at the lower level are expected to consider just the general conditions. Also, Pan and Tse (2000) and Erramilli, Sanjeev and Chekitan (2002) defined the non-equity modes, as modes that do not entail equity investment by a foreign entrant, and are becoming increasingly popular among service firms for organizing overseas ventures/operations. Non-equity modes are especially popular among consumer- 
services firms (such as hotel and restaurant firms) as compared to professionalservices firms (such as consulting firms) (Erramilli, 1990). Non-equity modes are essentially contractual modes, such as leasing, licensing, franchising, and management - service contracts (Dunning, 1988).

In the context of foreign direct investment (FDI), substantial capital and an ability to absorb risk is often required. FDI also offers firms a higher degree of control over international business operations in the host country (Enderwick, 2001). Simultaneously, Pan and Tse (2000); Rajan and Pangarker (2000) also proposed equity modes which are defined as foreign direct investment (FDI), and split into equity joint ventures (EJVs). Equity Joint Ventures involve sharing of assets, risks and profits and participation in the ownership of a particular enterprise by more than one firm.

From the perspective of managerial control, the equity mode gives foreign firms more control from inception to demise (Hill, Hwang and Kim, 1990;

Madhok, 1997), and requires higher resource commitment for full control and ownership (Rhoades and Rechner, 2001; Chen, 2007). 


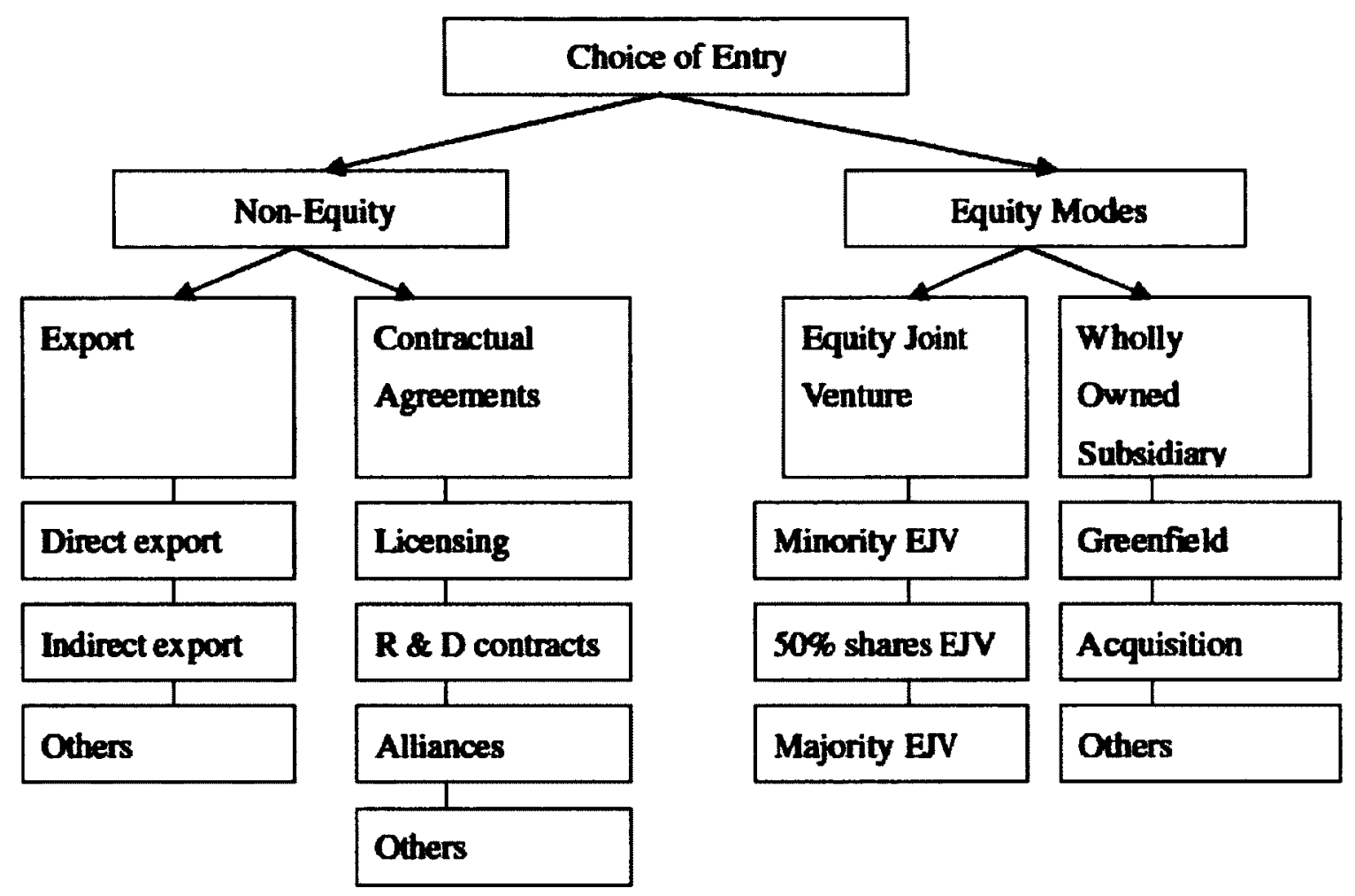

Fig.2: Choices of Market Entry Modes (Source: Pan and Tse (2000))

In summary, studies have identified the criteria that appear relevant in the effort to predict foreign market entry. These include, but are not limited to, classifying market entry modes into two categories based on their level of control, including full-control (i.e. wholly owned operation), and shared-control mode (i.e. contractual transfer or joint venture) Kotabe (2002). This is in relation to the equity and non-equity modes of entry. 
Classification of foreign market entry modes is not an easy task as it is dependent on many factors and each entry mode offers different benefits and risks (Chang and Rosenzweig, 2001).The most common first step toward foreign endeavour is still exportation. It is seen to be of low risk but not without its associated low market control by the foreign firm.

\subsection{Lesson Learnt}

1. The two prominent modes of technology transfer identified in the literature review are: Embodied mode (sales of products and services such as equipment and machineries) and disembodied mode (direct sale of knowledge and intellectual property)

2. From literature, there are two key entry modes namely equity and nonequity entry relationship. Equity base choice of entry enables the transferor to make a direct investment into the target market whilst collaborating with an identified firm in the host market. The equity ratio varies relative to the level of control that the transferor found relevant to their business pursuit. The non equity entry mode can be a joint or nonjoint venture agreement that has no monetary commitment but a form of contractual or representative relationship.

3. Location and ownership structure are two predictive dimensions of entry mode. Both dimension influences entry mode in varying degree depending on if the focus is to control sales or the market itself. Where market control is essential to technology transfer the ownership structure is define to favor the transferor. 
4. A firm ability to use technology transfer to create and appropriate value depends on its knowledge of the host market and the interplay of the market forces. Literature is rich with reasons on why firms go to foreign market. It ranges from their quest for high profit to search for cheaper labour (and cost of production) but little is available on how the effect of the market characteristics defines both technology transfer and the choice of entry mode.

5. Literature is rich on technology transfer activities of multinationals, small and medium scale enterprise to the developed nations and very few materials on the technology transfer activities to the developing nations. Small and medium business enterprises are often treated together in literature whereas they are likely to face different challenging scenarios especially in the developing nation where resource base could be stretched significantly. This creates a vacuum and limitations on what we know about small business technology transfer activities to the developing nations and how the challenges in the host market determine their course of action.

6. Globalization and the improvement in international transportation and communication has opened the opportunity for small companies with innovative technology to compete favorably with the multinationals as niche producers with a small range of technologies that offers easier learning opportunity to the developing countries.

7. Existing models on technology transfer requires that the transferee will have access to high-level engineering skills and should be involved in the 
planning right from the beginning. They equally places a high demand on the transferee to develop sound engineering and project management skills without which the technology transfer process cannot be managed effectively. This may not be possible to achieve in many of the developing countries and particularly so for small companies. Consequently it may be challenging for small companies to use these models. This makes it imperative to seek another informative host market entry model that allows a smooth and or manageable entry mode to the developing nation by the small companies.

8. The valuable lesson that emerges from the models is that it imperative for managers of technology to gain good insights into the transferee environment, transferor environment, and the greater environment when planning and implementing a technology transfer project.

9. The work of Jagoda (2007) and Ramanathan (2007) in categorizing the problems facing small and medium enterprises provide insight on areas of concentration whilst researching the host market to define the entry mode for small companies. The problem centers informed our areas of concentration during the interview and data analysis exercise. 


\section{Chapter 3}

\subsection{Research Method}

Chapter 3 is organised into three sections. Section 3.1 discusses the research design. Section 3.2 identifies the unit of analysis and section 3.3 describes the method used to prepare the deliverables.

\subsection{Research Design}

This research delivers

1. The market characteristics that define the entry mode a small Canadian company selects to sell to a developing nation.

2. Model of the relationship between market characteristics and key entry modes for small company

3. Propositions that define relationship between the market characteristics and the entry mode

To produce the deliverables, the research design used a cross sample analysis to compare different instances of entry mode of Canadian small companies. This is an inductive study that develops from data collected through an interview session with managers of small companies.

\subsection{Unit of analysis}

The unit of analysis is the response to questionnaire administered to the owners of small companies on their Market entry mode. 


\subsection{Method}

The method used in this research follows (Eisenhardt, 1989) for building management theory from examining data of a sample.

Table 4 below provides the steps of the research method.

\begin{tabular}{|l|l|l|l|}
\hline \multicolumn{2}{|c|}{ Steps } & $\begin{array}{l}\text { Dominant Activities to } \\
\text { produce deliverable }\end{array}$ & Output \\
\hline 1 & $\begin{array}{l}\text { Define } \\
\text { Research } \\
\text { problem }\end{array}$ & $\begin{array}{l}\text { Identify two domain: The source } \\
\text { of technology (Canada) and its } \\
\text { destination (Developing nations) }\end{array}$ & $\begin{array}{l}\text { Research question } \\
\text { and method }\end{array}$ \\
\hline 2 & $\begin{array}{l}\text { Selecting } \\
\text { Samples }\end{array}$ & $\begin{array}{l}\text { Identify clean technology sector } \\
\text { that are active in exportation and } \\
\text { relevant for the study }\end{array}$ & $\begin{array}{l}\text { Eight small Canadian } \\
\text { companies selected }\end{array}$ \\
\hline 3 & $\begin{array}{l}\text { Collect } \\
\text { data }\end{array}$ & $\begin{array}{l}\text { Ethics approval was obtained and } \\
\text { notices sent to potential } \\
\text { participants and interview } \\
\text { conducted }\end{array}$ & $\begin{array}{l}\text { Interview recording } \\
\text { and transcribed } \\
\text { scripts }\end{array}$ \\
\hline 4 & $\begin{array}{l}\text { Entering } \\
\text { the field } \\
\text { and Data } \\
\text { analysis }\end{array}$ & $\begin{array}{l}\text { Chunks of sentences and phrases } \\
\text { were grouped and coded to } \\
\text { identify line of thoughts and } \\
\text { concepts }\end{array}$ & $\begin{array}{l}\text { Sub categories and } \\
\text { core categories of } \\
\text { the market } \\
\text { characteristics }\end{array}$ \\
\hline 5 & $\begin{array}{l}\text { Memoing } \\
\text { Observations and emerging } \\
\text { thoughts were noted to explain } \\
\text { observed activities during } \\
\text { interview sessions }\end{array}$ & $\begin{array}{l}\text { Captures } \\
\text { researchers line of } \\
\text { thought on } \\
\text { phenomena }\end{array}$ \\
\hline 6 & $\begin{array}{l}\text { Build } \\
\text { models } \\
\text { from } \\
\text { analyzed } \\
\text { data }\end{array}$ & $\begin{array}{l}\text { Extant literatures were accessed } \\
\text { as data and compared with } \\
\text { observed data. }\end{array}$ & $\begin{array}{l}\text { Entry models and } \\
\text { Propositions }\end{array}$ \\
\hline 7 & $\begin{array}{l}\text { Discussion } \\
\text { of Result } \\
\text { and } \\
\text { reaching } \\
\text { closure }\end{array}$ & $\begin{array}{l}\text { Explanation of results and } \\
\text { presentation of Models }\end{array}$ & Discussions \\
\hline
\end{tabular}

Table 4: Steps and activities 


\subsubsection{Define Research Problem}

The research problem provides focus to the study. A general literature review follows with utmost care to avoid researchers' bias towards preconceived ideas whilst approaching the field (Glaser, 1992).

Small companies in Canada have their innovative technology on the shelves whereas the problem situations in the developing nation require solutions that such technology can resolve. The knowledge about the host market is limited and small companies are not prepared to commit their limited resources to an unknown market.

Two domain were identified namely (1) small companies with innovative ideas and solution are here in Canada and (2) The market in developing nations with problems that the technology solution of small companies can resolve. But the market situation in the developing nations is not well defined to the small companies to influence the commitment of their limited resources.

The study on small and medium enterprise (SME) choices (Jolanda Hessels and Siri Terjesen, 2007) gave good insight on possible line of inquiry using the grounded theory approach. Insight on knowledge of foreign market and market related determinants of entry mode formed the basis of this research work and it was investigated during the field interview. 
Two problem areas were identified namely (i) Small companies' knowledge of the host market is not sufficient to influence exportation and (ii) There is no established mode of entry for small companies to such market. The research question for this study is focused around this problem situation.

This two research questions are:

- What are the characteristics of the markets in developing nations that affect the way Canadian small companies enter them?

- What are the entry modes of small companies to the developing nation in a limited resource environment?

\subsubsection{Selecting the Sample}

A letter of intent (approved by the ethics board of Carleton University) was circulated among some small companies in the Province of Ontario inviting them to participate in the study. We got good responses but eight of them were conveniently selected to include one that is about to export whilst the remaining seven have been involved in exportation. This is within recommended margin of between eight and ten cases (Eisenhardt, 1989) for management case based research. Selection of sample was limited to clean technology industry selection was controlled to cut across industry to allow for generalization of our result. Seven of the participating companies have been involved in technology transfer for over a period of two years to both developing and developed nation whilst the eighth is about to export their first product. 


\subsubsection{Data Collection}

Primary data was collected via direct interview of respondents whilst secondary data collection was from the website of the participating organization on as the need arise basis. Literatures were treated as data and given equal weight as data collected from samples. Most of the extant literature will be assessed during the continuous comparison exercise to achieve saturation (i.e when new ideas no longer emerge in spite of new data). Interviews were recorded and transcribed to ensure details were adequately captured and subsequently analysed.

Structured and semi structured questions was administered to respondents. The respondents are chief executives of the small companies or their representatives who are versatile in their operations. Lines of enquiries were refined from one interview to the other to confirm an emerging concept and to conform to the condition of constant comparison as data emerge.

\subsubsection{Entering the Field and Data Analysis}

The respondents were advised with letter of information (as mentioned earlier) where the whole exercise was described and their consent requested. They were given enough notice to accept or reject participation. Detail briefing sessions before the interview provide good comfort to the respondents and all were able to discuss comfortably. Respondents' consent to be audio recorded was quite easy to obtain when they realize that attribution is purely conditioned upon their consent. 
We engaged in general discussion session after each interview and this proved rewarding and such informal comments will be relevant in the final analysis.

\section{Data Analysis}

Open coding: Transcribed interview sessions are separated into meaningful units of key words or phrases which connect the participant's description to the experience under study (Goulding, 1999). Numerical codes are assigned and it is the basis of conceptualizing and labelling data. Open coding starts the process of data analysis that assists in categorising many individual elements of the phenomena to identify market characteristics.

The transcribed interview session is analysed in an effort to recognise key words or phrases which connect the participant's description to the experience under study. This procedure, as Spiggle (1994) describes it, consist of "identifying a chunk or unit of data (a passage of text of any length) as belonging to, representing, or being an example of some more general phenomenon"

Axial Coding: The open coded data were compared across the sample and arranged into categories (similar to across cases analysis Eisenhardt, 1989a) and subcategories. As the relationships between categories emerge and some open codes become categories. This stage allows the development of concepts through the systematic analysis and constant comparison of data. This eventually results into categories which unite the concepts and reveal a 'gestaltian' theoretical explanation of the phenomenon under study (Goulding, 1999). 
Selective coding: This is the final stage of coding. Once the initial open coding exercise has resulted into unique categories, selective coding was done around the identified categories to identify core categories which encapsulate some initial categories whilst new ones are generated through the constant comparison of data. The core categories can serve as the basis for a grounded theory (Babchuk, 1997), but in this case they are the market characteristics. This process relates the core category to other categories and attempt to validate the relationships among them (Strauss and Corbin, 1990). The selective coding integrated the categories into core categories to form the market characteristics that will define the entry mode of small companies.

Memoing: Writing of theoretical memos is recommended by Strauss (1987), Glaser $(1978,1992)$ as a good process in inductive approach. Inspiration and ideas that came during coding exercise, especially on possible relationship between categories were noted as memo. The memos were used in developing the models.

Sorting: This is a process of grouping the results on the basis of the categories or properties they address and the relationships that has ensue among them. It assists in defining the eventual report presentation of the thesis. Microsoft word and excel spreadsheet were used to store all the data (raw data and coded data).

Write up: Data collection, coding, memoing, sorting will be followed by the write up stage to present the result of the analysis and findings. The sort structure will 
informed the report structure. It is expected to assist in integrating them into a coherent argument.

\subsubsection{Build Models and Propositions}

Models and Proposition will be developed based on the analysed data of the interview session and data from literature coupled with the experience of the researcher.

Responses from interview session that proffer solution to the challenges associated with technology transfers (Table 2) were aligned and integrated using the entry mode concept in literature (section 2.6) to design the models. This will be carried out at the latter end of this research. Circumstance base propositions will be drawn from the model.

\subsubsection{Reaching Closure}

Naturally the process should be stopped when complete saturation has been accomplished but in reality it is not always the case. As noted by Eisendhardt (1989), cases are planned and such plan may be necessary because of the availability of resources and time constraints. This is the situation with this study. The method in this chapter is as represented in the figure below. 


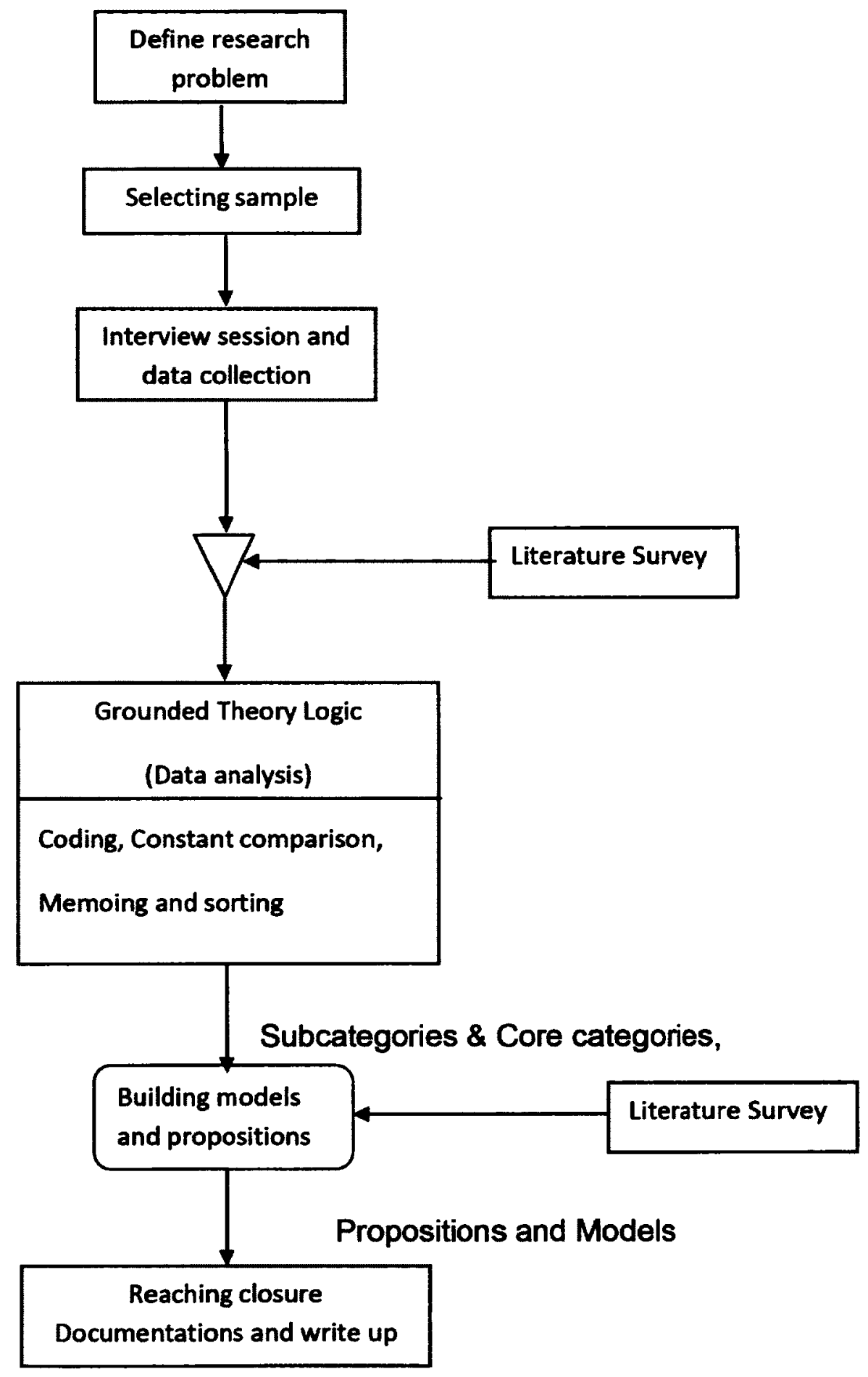

Figure 3: Research method 


\section{Chapter 4}

\subsection{Results}

Chapter 4 presents the results of the research. The chapter is organized into three sections. Section 4.1 describes the sample. Section 4.2 presents the result of the data analysis. Section 3 provides the deliverables.

\subsection{Sample} In selecting the small companies, a letter of intent (as approved by the ethics board of Carleton University) was circulated among some small companies in the Province of Ontario inviting them to participate in the study. The letters were addressed to their chief executives. We got good responses but eight of them were conveniently selected and it included one that is about to export whilst the remaining seven have been involved in exportation for over two years. Selection of sample was limited to clean technology industry (to assume for a common environment) whilst cutting across at least two industries to allow for generalization in our outcome. Seven of the participating companies have been involved in technology transfer to both developing and developed nation whilst the eighth is about to export their first product.

Six of the chief executive officers agreed to be interviewed whilst two appointed their representatives. 


\begin{tabular}{|c|l|l|l|}
\hline Company & Industry & Exporting & Product Type \\
\hline A & Water Engineering & Yes & Environmental services \\
\hline B & Power generation & Yes & Electric storage system \\
\hline C & Power generation & Yes & $\begin{array}{l}\text { Power from Bio-fuels } \\
\text { and natural gas }\end{array}$ \\
\hline D & Power generation & About to & $\begin{array}{l}\text { Powrer from Solar } \\
\text { Energy }\end{array}$ \\
\hline E & Power generation & Yes & $\begin{array}{l}\text { Power from Solar } \\
\text { Energy }\end{array}$ \\
\hline F & Power generation & Yes & $\begin{array}{l}\text { Powrer from Bio-fuels } \\
\text { and natural gas }\end{array}$ \\
\hline G & Power generation & Yes & $\begin{array}{l}\text { Power transmission } \\
\text { systems }\end{array}$ \\
\hline H & Pulp and paper & Yes & $\begin{array}{l}\text { Quality control } \\
\text { equipment }\end{array}$ \\
\hline
\end{tabular}

Table 5: Variation within the samples

- Six of the companies are in the business of power generation, one in water engineering and the eighth in the pulp and Paper industry.

- Six of the sample in power generation and one of them is in the production of electric power transmission equipment.

- All the samples are already exporting technology except one with the challenge of getting her first product into the foreign market, though at an advanced stage to commence export. 
The data collected are qualitative in nature. They are mainly the transcribed interview sessions held with the six chief executives of the small companies and two representatives as mentioned above. The transcribed data were coded to identify the market characteristics as reported below. Details of the coding are as presented in the appendix $A-M$

\subsection{Results}

The transcribed interview sessions were broken into separate units of meaning using the open coding method specified in section 3.2.5. A total number of 421 codes were used to connect the participant's description to the different market characteristics of the developing nation in the data set (Appendix $A-H$ ).

The market characteristics identified in the open coding were grouped into categories through the axial coding method (cross case comparison and grouping of similar chunks of data, section 3.2.5) identifying their consistency across the eight companies. The result of this axial coding is as shown in table 6 below. Column two indicate the total number of codes that accounts for each category of market characteristics as define in the transcribed interview. Some key comments of the respondents are included. The result of coding all the transcribed data is as presented in appendix $\mathrm{A}-\mathrm{H}$ 


\begin{tabular}{|c|c|c|}
\hline Market Characteristics & $\begin{array}{l}\text { Total number of } \\
\text { code count that } \\
\text { informed } \\
\text { characteristics }\end{array}$ & Quotes from Transcribed data set \\
\hline Clients Need & 52 & $\begin{array}{l}\text { "good information.. focused information that leads } \\
\text { you to your right market...", " We use local agents to } \\
\text { search the market to collect data as needed..." }\end{array}$ \\
\hline Access to finance & 34 & $\begin{array}{l}\text { "The government appears to have place a ceiling on } \\
\text { what they are willing to finance and guarantee. .", ". } \\
\text { we cannot provide the necessary funding for all we } \\
\text { have to do. ." }\end{array}$ \\
\hline Payment for projects & 7 & $\begin{array}{l}\text { "Payment is critical to us. Exporting abroad can drain } \\
\text { our resources, hence the reason for security of } \\
\text { payment", "it is a world bank funded project. .. } \\
\text {.payment will not fail..." }\end{array}$ \\
\hline Risks in market process & 9 & $\begin{array}{l}\text { "Volatile market pose challenges to financial and } \\
\text { insurance institution and that present a wall of } \\
\text { resistance to easy access to the market. . ", "Does the } \\
\text { customer have the capacity to issue the project. ." }\end{array}$ \\
\hline Technology type & 11 & $\begin{array}{l}\text { It is a relatively new Tech as such market must be well } \\
\text { developed to support the project" , "Not a stand- } \\
\text { alone type of technology, it require an umbrella } \\
\text { organization to transfer... " }\end{array}$ \\
\hline Technology gap & 10 & $\begin{array}{l}\text { "It is a relatively new Tech as such market must be } \\
\text { well developed to support the project", " Technology } \\
\text { gap between end user and supplier hinder transfer.." }\end{array}$ \\
\hline Government stability & 13 & $\begin{array}{l}\text { "Government stability still constitute a substantial } \\
\text { percent of factors that determines approach to the } \\
\text { market place", ". . instability in government leads to } \\
\text { high level of risk perception and ... .restrain in the } \\
\text { release of funds }\end{array}$ \\
\hline Level of education & 20 & $\begin{array}{l}\text { "we are dealing with people who have good } \\
\text { education. ." "... level of education in the target } \\
\text { market is of high consideration for... .access. ." }\end{array}$ \\
\hline Support services & 15 & $\begin{array}{l}\text { "Users require local presence in the market. . ", ". . } \\
\text {.need a local number to call when there is problem } \\
\text { with product..." }\end{array}$ \\
\hline
\end{tabular}

Table 6: Basic Market Characteristics identified in the data set

The final step of coding were selectively done around the categories that emerged from the last cross case coding (axial coding) to identify the dominant market characteristics across the companies whilst related and similar 
characteristics were integrated and sorted according to the relationship that exist among the characteristics. The outcome of this selective coding is the five core categories of market characteristics of the developing nations as represented in Appendix I-M. The summary is as presented in table 7 below.

\begin{tabular}{|l|c|}
\hline \multicolumn{1}{|c|}{\begin{tabular}{|c|} 
Five Core Market \\
Characteristics
\end{tabular}} & $\begin{array}{c}\text { Total number } \\
\text { of code count } \\
\text { that informed } \\
\text { characteristics }\end{array}$ \\
\hline Market Knowledge & 53 \\
\hline Limited Resources & 45 \\
\hline Market Environment & 26 \\
\hline Absorptive Capacity & 36 \\
\hline Type of Technology & 22 \\
\hline
\end{tabular}

Table 7: Core Market Characteristics

Table 8 below shows each core characteristics as a ratio of the total sum of codes that defines the five core characteristics. This is expressed as weights in column three. The total sum of the weight is 1. 


\begin{tabular}{|l|c|c|}
\hline Characteristics & $\begin{array}{c}\text { Total } \\
\text { Codes }\end{array}$ & Weights \\
\hline Market Knowledge & 53 & 0.29 \\
\hline Limited Resources & 45 & 0.25 \\
\hline Market Environment & 26 & 0.14 \\
\hline Absorptive Capacity & 36 & 0.2 \\
\hline Type of Technology & 22 & 0.12 \\
\hline
\end{tabular}

Table 8: Number of codes and associated weight of market characteristics

\subsection{Answers to Research Questions and Deliverables}

The two research questions were:

- What are the characteristics of the markets in developing nations that influences the entry mode strategy adopted by Canadian small companies?

- What are the key entry modes of small companies in a limited resource environment?

Answers to the first question of the study are the five core market characteristics namely: Market knowledge, limited resources, market environment, absorptive capacity and type of technology. The characteristics will be discussed in chapter 5.

Three different entry modes were defined by the market characteristics namely:

Strategic partnership entry mode, Local agent entry mode and Local organization 
affiliation entry mode. The models are as shown in figures 4 to 6 below and together they answer the second research question.

Strategic Partnership mode is the exportation to host market through a partnership arrangement with a home base organization. This is an indirect entry mode.

The local Organization affiliation mode is an indirect entry to host market through an alliance arrangement with a local organization (in the host market) to access the market.

Local agency mode is a direct entry to the host market using market base agent to access the market.

The strategic partnership entry mode is defined by the elements of the market environment, absorptive capacity and the market's limited resources. Details of their codes and respondents comments are in appendix J, K \& L.

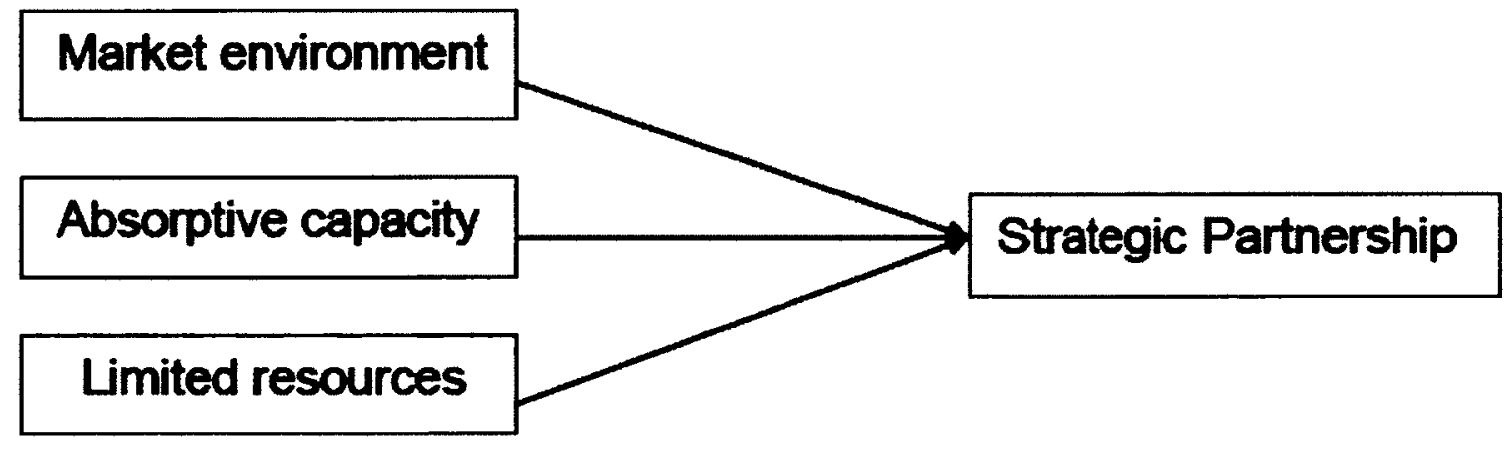

Fig. 4: Strategic partnership entry model 
The market environment and market knowledge characteristics of the market combined to define the local agent entry mode. It is a mode that relies on the availability of professional local agents in the host market. Appendix I \&K combine to define this mode.

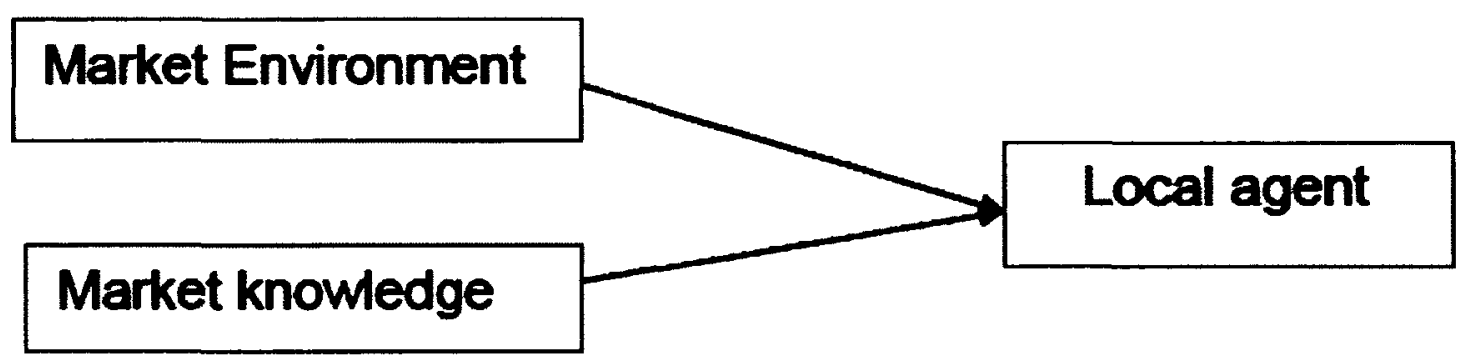

Fig. 5: Local agent entry model

The local affiliation entry mode is defined from the combined effects of market environment, market knowledge and absorptive capacity characteristics of the market (appendix I, K \&L).

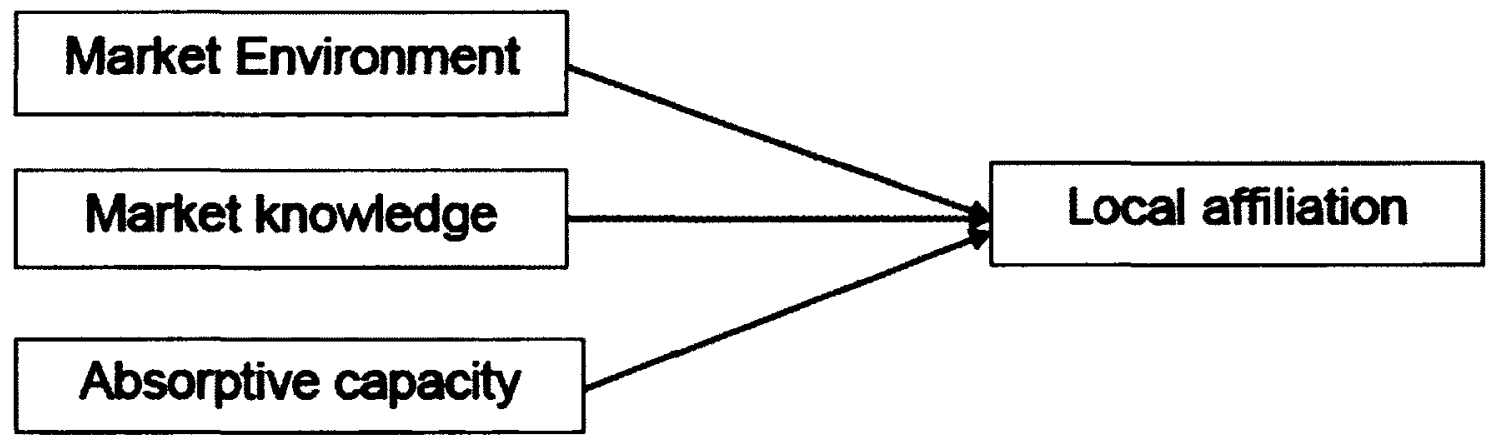

Fig. 6: Local organization affiliation model

Three key propositions were developed (from the model, the coded transcribed data and literature) namely: 
P1: Strategic alliance entry mode will be of high preference when host market is known for instability and resource constraint whilst absorptive capacity is low.

P2: The likelihood of a direct entry mode through the aid of host market agency is high when professional agents are available and product technology base is perceived as simple.

P3: When technology need is established in a highly restrictive environment with sufficient absorptive capacity, the likelihood of small company using the local organization affiliation entry mode is high.

Further discussion on the entry modes and propositions are presented in chapter 5. 


\section{Chapter 5}

\subsection{Discussions of Result}

Chapter 5 provides a discussion of the results presented in Chapter 4 . Chapter 5 is organized into 2 sections. Section 5.1 provides discussion on the market characteristics, section 5.2 discusses the entry models and proposition.

\subsection{Discussion}

Literature is sparse on the activities of small companies in the area of technology transfer to developing nations. Challenges confronting multinational organizations are readily available and when small companies are considered, they are treated jointly with medium sized enterprise with an assumption that they face similar challenges in the market.

The challenges of multinational and small and medium enterprise (treated together) as obtained from literature serve as a guide to investigate the market challenges of the small companies.

\subsubsection{Market knowledge}

The market knowledge portion of the market characteristic includes elements such as the Client's requirements, market code of conduct, activities of 
incumbent in the market, risks, safety, security issues and challenges associated with the product sector.

Market knowledge provides answer to most of the challenges facing transferor under the technology transfer process issues in Table 2. It consists of market information that aligns the objective of the transferor and the transferee by providing how the proposed technology resolves the need in the market. Market knowledge provide information on the various aspect of market risk (i.e factors that influences timely project completion in the environment, repayment risk associated with loans, information on continuous availability of skilled human resources, risks associated with change in government regulations, risks of insecurity of life and properties). Host markets are unique institution with both written and unwritten code of operation, formal and informal conducts and it is the market knowledge that provides information on the codes and conducts. Dynamics of markets in developing nations underscore the need for the working knowledge of the market. Brokers and agents are facilitator of this unique market knowledge. Interaction with respondents shows that small companies will avoid pushing their products or technology into the market because they lack the resources to perform all the associated trainings, advert and promotional activities that is required for the product/technology to overcome the market hurdles and challenges. Respondents' emphasis on market knowledge translates to a better understanding of the need in the market which results in market pulling effect on their product or technology as defined by John Masten and Alan Miller (1995). 
The pull strategies begin with identifying the need in the marketplace that defines the technology to solve the problem whilst Push strategies begin with specific technology that seeks for acceptance and patronage in the market place. Expectedly, the pull strategy yield relevant information that are perfect representation of client's problems in the host market and always require less effort to sell.

Table 8 (section 4.2) present the weighted ratio of the market characteristics. Market knowledge has the highest weight ratio of 0.29 out of a maximum of 1.0 to emphasise the importance of adequate information and clear understanding of market operations to the small companies if they want to embark on technology transfer to the developing nations.

Market knowledge has shown that technology flow into a recipient economy will be limited where market information is not readily available or accessible to potential transferor and this is consistent with the findings of Andrea Fosfuri (2003)

\subsubsection{Limited resources}

Limited resources explain the insufficiency of resources in the host market and the inability of transferors to finance technology transfer projects in the host market. 
Small companies are associated with limited resources in comparison with bigger organizations (Coviello and McAuley, 1999; Knight, 2000; Hollenstein, 2005). Access to finance constitute major element of the market limited resource characteristic. Projects or service base technology transfer for the developing nations are not readily funded and support from financial institutions is subject to different constraints as confirmed by respondents (appendix J). Small scale Enterprises are more likely to face resource scarcities, e.g. in terms of financial and human resources (Coviello and McAuley, 1999). Limited resources as one of our findings are consistent with literature that scarcity of resources limit the capacity of small companies to act upon identified foreign opportunities.

The result of the weighted ratio in Table 2 shows limited resources in the second position relative to market knowledge. This in a way provides us with their order of relevance to small companies in their bid for the host market. This is also consistent with empirical findings that resource scarcities may indeed (in some instances) prevent small firms from internationalizing (Westhead, Wright and Ucbasaran, 2002). Resource base theory entry mode (section 2.5.1) accepts resources as determinants of entry mode and its strategic deployment affects the performance in the market. Respondents emphasize inadequate resources in the host market as a determinant of their entry mode choice. Limited resources include unavailability of investor funds, insufficient/lack of professional agents and intermediaries in the host market... Small companies are restricted as a result of insufficient basic resources in the host market and this equally affects their choice of entry. 
Indirect exportation is usually the most preferred starting mode for companies lacking substantial resources (or access to such resources in their host market) and knowledge of the international market as reflected in the model discussed later on in this chapter. This is consistent with the non equity entry mode for companies that are interested in sales without controlling the market (section 2.6.1); it minimizes their overseas involvement and risk. It can be safely stated that when a small company cannot afford a sustainable operation in the host market (due to lack of resources within the host market) it will choose a less risky access.

\subsubsection{Market Environment}

Market environment is composed of different elements of the market place. It includes bureaucratic process, local regulations, security and safety, government stability, civil unrest, inconsistency in policy guidelines and tax issue. The market environment in the developing nations is expected to be unstable and to a large extent unpredictable as noted in past studies Jean-Claude Berthélemy et al (2002) The effects of bureaucratic process, corruption and associated delays have been highlighted severally in the study of internationalization of multinational organizations (Claude Marcotte \& Jorge Niosi, 2000) and the environment is not different for small companies and the pressure is expected to be intense on them. The outcome of this research confirms as the data identify the market environment as a characteristic of the host market. Respondents did not translate the fluidity of the environment as a deterrent; instead they were 
ready to view the environment in perspective. Respondents confirmed there is element of risk in every market that has high potential value in return on investments and those of the developing nations market are compelling enough to attract entry. Small companies, in spite of limited resources, are willing to endure the bureaucracy associated with the processing of export documentation during which time they earn no revenue. As such small companies are willing to take the risk. Our findings shows that small companies are willing to go to the developing nations in spite of the dynamic and unstable market environment but the mode of entry would be such that limits their level of financial commitment and liability. Market environment therefore contribute to the strategic partnership entry mode discussed in section 5.2.1 below.

\subsubsection{Absorptive Capacity}

Poor physical infrastructure, inadequate supportive institution, lack of good education and technology policy guidelines together defines the capacity of the market to absorb technology. Absorptive capacity defines the ability of the host market to internalize the knowledge acquired through the technology inflow. It is also the characteristic that defines the diffusion process (the spread of technology) into the local market (Appendix J).

Market's ability to identify, acquire and use acquired knowledge is a determinants of the type of technology that the market can accept. Our data set indicate that most markets in the developing nations lack the ability to identify their need and it 
often result in oversized facilities. Extant literature holds that a country need to reach a minimum human capital threshold in order to benefit from technology transfer (Cohen and Levinthal, 1990; Lall, 1992; Xu, 2000). Level of formal education in developing nations is quite low and invariably low absorptive capacity is highly associated. Small companies then find it difficult to export into market that cannot absorb and sustain their product, technology or services. This scenario influences their alliance entry mode with home organization or existing foreign organizations that can afford to support or provide after sales foreign operations (for their after sales services).

Basic infrastructures are also required for successful technology transfer and they equally define the readiness of a market to accept or absorb technology. Universities and polytechnics capable of generating skilled technicians, engineers and scientists, as well as undertaking some level of basic and applied research and development are not well funded or equipped in the developing nations. The combination of the formal education and availability of infrastructures improves the absorption capacity of the market as a whole and is expected to act as a mechanism to overcome market failure (Naula R, 2004).

Policies are the drivers of productive collaboration between firms, individuals and universities and it promotes entrepreneurial spirit. Lack of good policies translate to as low level education, undefined market standards (that protect intellectual properties), lack of power and basic amenities of life which invariably defines absorptive capacity of the market as a whole. 
Substantial number of developing nations has issues with governance and such efficient policies are not in place resulting in an environment that is not encouraging to potential foreign small companies. Since government is always the market facilitator and provider of location-specific assets (Narula R, 2003a), absorptive capacity thus become an important market characteristic that can define entry mode of small companies if their technology can be rated as above average.

\subsubsection{Type of technology}

Every product, project or services has an underlying technology that defines its uniqueness to solve a specific problem. The technology base is a product feature but it cuts across to become a market characteristic. When the technology base of a product is deemed simple, it is readily accepted and otherwise if it is perceived as complex or difficult to incorporate into their prevailing market technology. This is a function of the technology gap in the market (technology gap is the relative position of a market to the global standard of the industry in question). This characteristic defines the acceptability of the product, project or service in the market. It equally defines the type of after sales service required by the market and it raises questions on the capability of the small companies to maintain their presence in the market to provide such service. The market "type of technology characteristic" positively influences the strategic partnership model as discussed in details in section 5.2 .1 below. 


\subsection{Market Characteristics- Entry Mode Model}

The five market characteristics (discussed in section 5.1 above) combined differently to define at least three (3) entry modes for small companies venturing into the viable markets of the developing nations. Three identified possible entry modes are strategic partnership, Local Agency, local affiliation and these are all embedded in the data set and it reflect the low control non equity modes of section 2.6.1.

\subsubsection{Strategic Partnership Model}

Small company $\mathbf{G}$ has operations in Nigeria, Cuba and Angola. Entry attempt to Angola market was challenging as a result of the consequences of the civil wars that has ravaged the nation over the past few years. Education system has collapsed and absence of professionals and competent personnel in this market poses restriction to reconstruction activities. This is an average picture of the developing nations and resources are grossly limited in the market and costs of sustaining foreign operations were restrictive. The risk associated with client's ability to pay for any worthwhile project is high coupled with the need for the small company to maintain a visible presence in the market. This translates to indirect demand for commitment of high volume of resources which most small Canadian companies cannot afford. Pronounced scarcity of resources in a target market, as a result of social disturbance may indeed, in some instances prevent small firms from internationalizing (Westhead, Wright and Ucbasaran, 2002). Company $\mathbf{G}$ identified an old allied, a bigger Canadian contractor currently in Angola to access the market through a partnership alliance. 
Where the level of formal education is low, overall absorptive capacity of the market will be low and it consequently determines the level of local support available in the target market, cost of sustaining ground operation and support services. Under such condition, small companies should choose strategic alliance path to the market. The strategically chosen organization provides the necessary access and ground support for the small companies, usually associated with a minimal additional operating cost to the SCs (but not comparable to their cumulated benefits). Samples C, F, G and $\mathbf{H}$ expressed their inability to transfer directly at one time or the other because of the inability of the local operators to demonstrate an appreciable level of required knowledge to accept technology (absorptive capacity).

Strategic partnership market entry model defined by three of the market characteristics was designed as shown in figure 4 , section 4.3 and operationalized below in fig 7

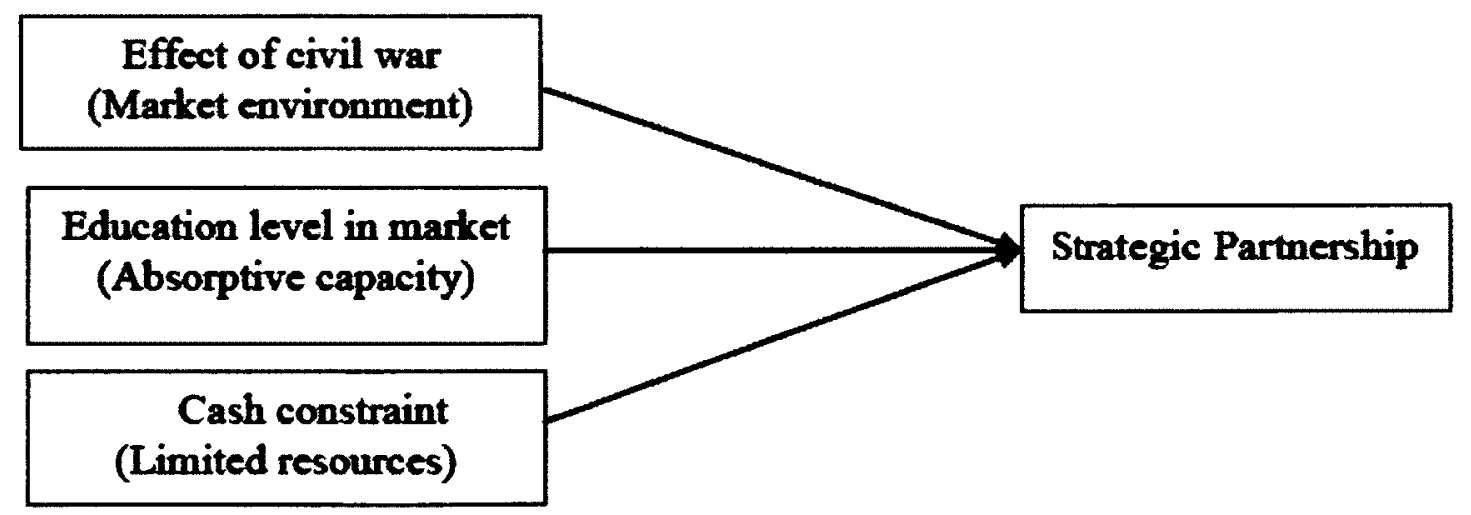

Figure 7: Strategic partnership entry model 
The information available in the market environment characteristic, in the case of respondent $\mathbf{G}$, provided information on the after effect of war and the associated instability in the market, The absorptive capacity of the host market, also in the case of respondent $\mathbf{G}$, will inform the transferor that there will be no formal education in such market for a while. This will inform their choice on ability to survive the market demands. Associated limited resources in such a market are expected. The war would have prompted emigration of skilled labour and alternative provision is inevitable.

In another scenario the choice of strategic partnership can be influenced by the bureaucracy element of the market environment characteristic. The level of bureaucracy and unwholesome activities associated with bribery and corruption translate into endless waiting for export documentations (Table 2, section 2.2.1, environmental problems) whilst earning no profit. The multinationals or bigger firms usually have better negotiating power in such market and the partnership arrangement should provide the required shield for the small companies to operate in such market.

This entry mode is also positively influenced where the market risk content poses difficulty in securing letter of credit or loan to finance projects (limited resources). Financial policies in developing nations do not support easy repatriation of return on investment and this becomes an immediate challenge to small companies. The proposed strategic partnership is a useful entry mode especially when the opportunities in the specific market are attractive and yields high retums. Extant 
theory holds that multinational enterprises have capacity to maintain their foreign activities without recourse to external funding (Hollenstein, Heinz, 2005), consequently the less risky path is for SCs to opt for alliance, especially where the multinationals (MTN) do not possess the unique technology of the SC as in the case of respondent $\mathbf{H}$.

The first proposition was formulated based on this entry mode and its associated explanations...

P1: Strategic alliance entry mode will be of high preference when host market is known for instability and resource constraint whilst absorptive capacity is low.

\subsubsection{Local Agency Model}

Information about the host markets are scarce and available data from export development agencies and export institutions are basically statistics that lacks predictive ability to influence the commitment of scarce resources of the small companies. Consequently small companies are in search of specific information and essential knowledge of the market (especially in the developing nation) to influence investment.

The use of host market local agent to access this requisite knowledge was expressed by all respondents as a key factor in their internationalization effort. Most respondent were willing to access the market by engaging the services of a well informed local agent who knows both the operational mode and working knowledge of the market. A professional and well informed agent in the local 
market is abreast of the type of technology most needed in the market to prevent the potential small company from pushing its product as against just responding to the pulling effect of the market. Respondents $E$ and $\mathbf{G}$ confirmed the use of local agent to acquire the necessary knowledge of the market to access Uganda and the Nigerian market respectively.

The local agent entry mode is defined by the market environment and market knowledge characteristics. A professional agent will handle all the local import documentation process and the unpleasant bureaucracy associated with speed money and policy guidelines. This professional agent also have capacity to provide a good level of comfort through their provision of well articulated knowledge of the market to bridge the information gap that is widely acclaimed among the respondents (also established in literature, Table 2 section 2.2.1) as being the major hindrance to their internationalization effort.

From the transcribed interview data, the more the uncertainty in a market environment the more likely small firms will seek assistance to access the market. Therefore it is expected that as the market environment of the developing nation has been observe to be filled with uncertainty and risks, small businesses are more likely to choose an entry mode that places demand on an on-ground agent. This explains why the market environment element of the market characteristics defines the local agent entry model. 
Respondents B, E and G used a local agent in India, Uganda and Nigeria respectively to access the market because the local agent was able to close the market knowledge gap to facilitate access to their host market.

Further observation of the sample reveals that respondents that subscribe to this mode of entry has product with simple technology. Where the technology is deemed to be simple, limited resources and absorptive capacity characteristic of the market will not have a profound effect in defining the entry mode. Transferor will only be concern with the need for technology in the market and the environment related issues. The local agency entry mode is a ready mode for such small companies in their bid for the viable market of the developing nation. The operational version of the model is reproduced in figure 8 below. This model equally informs our second proposition:

P2: The likelihood of a direct entry mode through the aid of host market agency is high when professional agents are available and technology is perceived as simple.

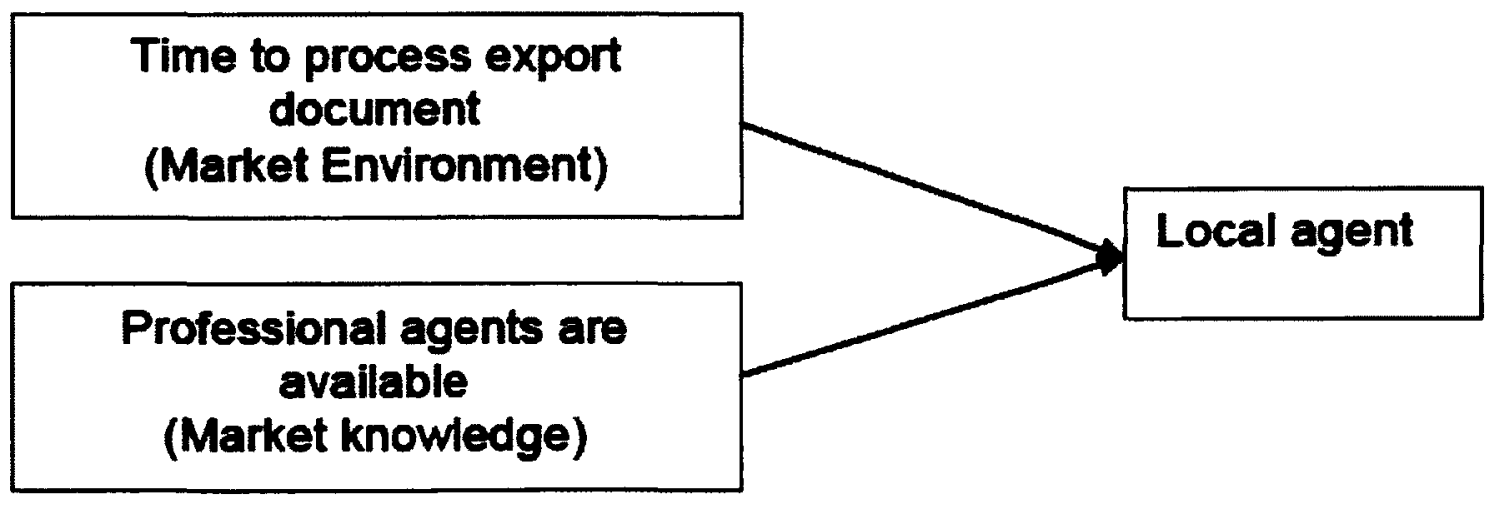

Figure 8: Local Agent entry Model 


\subsubsection{Affiliation Model}

Market environment may indicate that the environment is not friendly to foreign owned organization whilst their technology is highly needed in the market (i.e market knowledge characteristics is favourable), small companies can still access such market through the use of local affiliation entry mode. The absorptive capacity in such situation will be just above average and small companies need to identify and broker terms of affiliation with a locally established firm in the host market through which it carries out local projects, sales or marketing activities. The arrangement may be on equity or non equity basis depending on the regulations in the market environment and the need of the small company to control the market and her intellectual property if applicable (section 2.5). Respondent $F$ and $\mathbf{G}$ have a very attractive technology that could not be transferred due to a restraining market environment that specified some measures of import restrictions and government regulations. The respondents identified a local firm and broker an affiliation agreement to facilitate the transfer.

The third entry mode, based on the local organization affiliation is shown in its operational format in figure 9 below. 


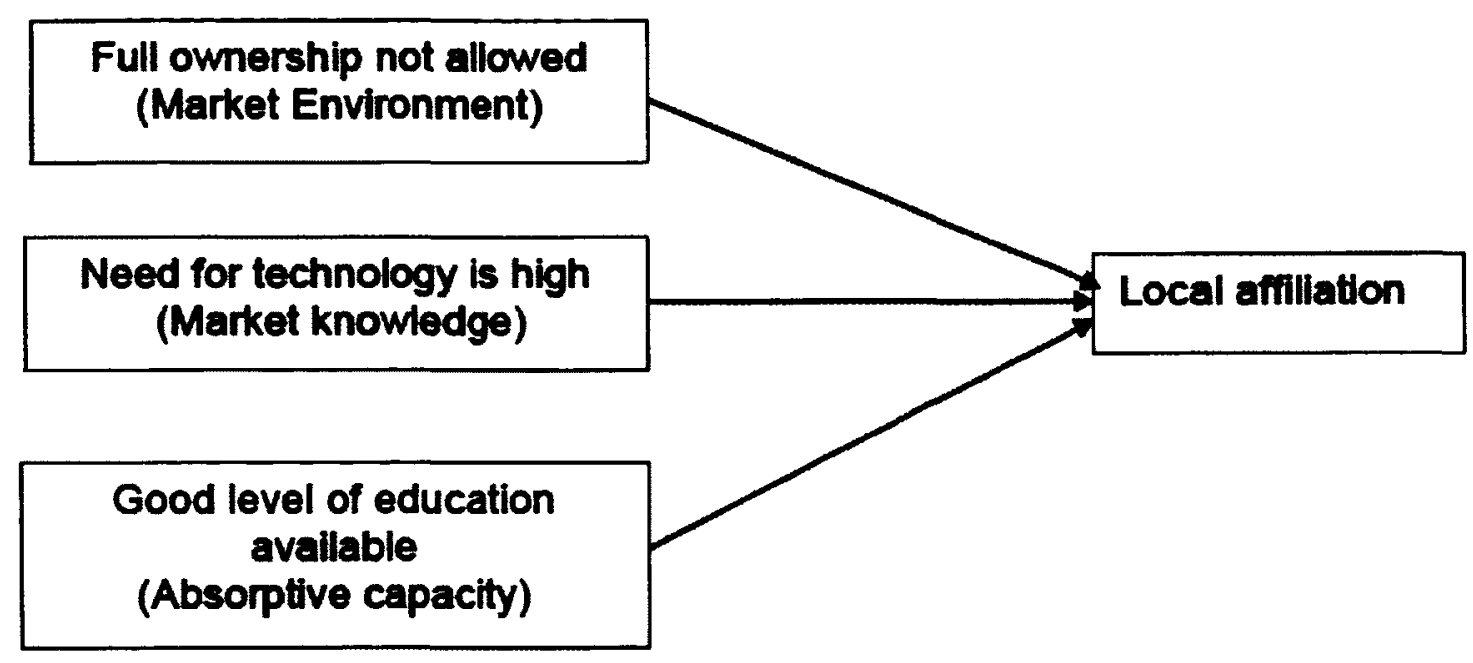

Figure 9: Local affiliation entry model

The absorptive capacity element of the market characteristics influences the local affiliation arrangement. When perceived as being above average it influences sufficient interest that encourage affiliation entry mode. Most developing nations have quite a number of companies on affiliation mode technology transfer consequent upon high risk perception of the market by the transferor.

Our third proposition, earlier presented in chapter 4 is:

P3: When technology need is established in a highly restrictive environment with sufficient absorptive capacity, the likelihood of small company using the local organization affiliation entry mode is high. 


\section{Chapter 6}

\subsection{Conclusion}

Chapter 6 is organized into three sections. Section 6.1 describes the conclusions of the research. Section 6.2 identifies the limitations of the research. Sections 6.3 suggest future research paths.

\subsection{Conclusions}

This research was designed to determine the characteristics of the market in developing nations and how they define the entry mode of small companies in their exportation effort to developing nations. Two key questions were answered:

1. What are the characteristics of the markets in developing nations that influences the entry mode strategy for Canadian small companies? 
2. What are the key entry modes of small companies in a limited resource environment?

The result of this research show that five key characteristics of the market in developing nation defines at least three entry modes for small companies. Three propositions were also developed based on the entry modes. The market environment, market knowledge, market limited resources, type of technology and the market absorptive capacity are market characteristics that defines the entry mode for small companies.

This results support the idea that small company embark on their internationalization effort through exportation without any equity participation or commitment to the host market operations. This is established in the affiliation and strategic entry choice of small companies as reported in chapter 4.

The following conclusions can be drawn from the present research:

- The knowledge about the client need, operations and code of conduct of the host market is of high priority to small companies in their choice of entry. All the respondents emphasized this key market characteristic during the interview session.

- Host market with highly qualified professional agents encourages small companies to embark on a direct access to the developing nations. 
- Small companies will readily adopt an entry mode that offers the least cost, such as non-equity affiliation, strategic alliance or contractual agreement, to transfer technology.

\subsection{Limitations}

This research has three limitations. First, only a small number of managers of small companies were interviewed. The results cannot be generalized at the industry or regional level.

All the managers of the small company we interviewed are located in the Province of Ontario and this may translate to a unique environment that may not be generalizable to other environments.

This research interviewed managers of small Canadian companies. Results are based on these interviews. The writer did not have an opportunity to interview managers of organizations operating at the market end. Analysis of the market can therefore be said to be transferor biased.

\subsection{Future Research}

Three suggestions for future research are advanced:

- First, this research can be replicated using a larger sample of managers. 
- Second, the benefits of creating a "keystone" type of a clearing house to facilitate small company's intemationalization effort can be researched. All the respondents suggested that a central organization that could act as a "clearing house" for internationalization could benefit small companies.

- Third, it is suggested that how the five market characteristics affect the three modes in different industry can be studied.

- This research can be further validated by an empirical studies that incorporate existing quantitative data set 


\section{References:}

Aidt, T.S. (2009), "Corruption, institutions, and economic development" Oxford Review of Economic Policy, 25( 2):.271-291.

Andrea, F. (2003). Country risk and the international flows of technology: Evidence from the chemical industry. Universidad Carlos III de Madrid and CEPR, London.

Arora, A. \& Gambardella, A. (2010). "Ideas for rent: An overview of markets for technology". Industrial and Corporate Change, 19(3): 775-803.

Athreye, S. \& Cantwell, J. (2007). "Creating competition? Globalisation and the emergence of new technology producers". Research Policy, 36(2): 209-226.

Martins, B. (1998). Information Liberation. London: Freedom Press.

Barney, J. (1991). "Firm Resources and Sustained Competitive Advantage," Journal of Management (March), 17(1): 99-120.

Chesbrough, H. (2003) Open Innovation: The New Imperative for Creating and Profiting From Technology. Cambridge, MA: Harvard Business School Press.

Christensen, C.M., Roth E.A. \& Anthony, S.D. (2004). Seeing What's Next: Using Theories of Innovation to Predict Industry Change. MA: Harvard Business School Press

Christensen, C.M. (1997) The innovator's dilemma: When new technologies cause great firms to fail. Boston, MA: Harvard Business School Press

Chung, H. \& Enderwick, P. (2001) “ An investigation of market entry strategy selection: Exporting VS Foreign direct investment modes, a home and host country scenario" Asia Pacific Joumal of Management, 18(4): 443 - 469.

Marcotte, C. \& Niosi, J. (2000), Technology Transfer to China, The Issues of Knowledge and Learning, Journal of Technology Transfer, 25: 43-57.

Czinkota, M. and Ronkainen, A. I. (1996), Intemational Marketing, Fifth Edition. The Dryden Press.

De Clerq, D., Sapienza, H. \& Crijns, H. (2005). The internationalization of small and medium sized firms. Small Business Economics, 24(4): 409-419

Fletcher, D. (2004) "International entrepreneurship and the small business" Entrepreneurship \& Regional Development, 16(4): 289-305. 
Fosu A.K, (1992) "Political instability and economic growth: evidence form subSaharan Africa." Economic Development and Cultural Change 40 (4): 829 -841.

Grant, R. M. (1991) "The resource-based view of competitive advantage: Implications for strategy formulation" California Management Review 33(3): 114135.

Hoekman M. Bernard, Keith E. Maskus \& Kamal Saggi (2001), Transfer of Technology to Developing Countries: Unilateral and Multilateral Policy Options.

Hollenstein, H. (2005), Determinants of International Activities: Are SMEs Different? Small Business Economics, 24 (5): 431-450.

Ian J. Payton, Michael Fenner \& William G. Lee (2002), Keystone species: The concept and its relevance for conservation management in New Zealand.

lansiti, Marco, \& d Roy Levien, (2004) "Strategy as Ecology" Harvard Business Review 82, no. 3

Jagoda, K. I, (2007), A Stage-gate Model for Planning and Implementing International Technology Transfer. University of Westem Sydney, Australia.

Jean-Claude Berthélemy et al (2002), Political instability, political regimes and economic performance in African countries.

Masten, J. \& Miller, A. (1995), Overcoming Barriers to Technology Transfer Between Small Business Assistance Agencies and Their Clients: Third World Style. 48-54

Jolanda Hessels, Siri Terjesen \& Zoetermeer, (October 2007), SME Choice of Direct and Indirect Export Modes: Resource Dependency and Institutional Theory Perspectives.

Jolanda Hessien \& Siri Terjesen, (2004), SME Choice of Direct and Indirect Export Modes: Resource Dependency and Institutional Theory Perspectives.

Niosi, J. \& JRivard, J. (1990), Canadian Technology Transfer to Developing Countries through Small and Medium-Size Enterprises, World Development, 18 (11): 1529-1542.

Lichtenthaler, U (2005), External commercialization of knowledge: Review and research agenda. International journal of Management Reviews 1(A): 27, 1-255.

Narula, R. (2004): Understanding absorptive capacities in an "Innovation Systems

Context: Consequences for Economic and Employment Growth". DRUID working paper No 04-02. 
Narula, R, (2003a), Globalisation and technology: Interdependence, innovation systems and industrial policy. Cambridge,: Polity Press

Paine R.T (1966) "Food web complexities and species diversity" American naturalist 100: 65-75.

Peng, M.W. \& York, A.S. (2001). "Behind intermediary performance in export trade: Transactions, agents and resources" Journal of International Business Studies, 32(2): 327- 346.

Power, M.E; Timan, D et al, (1996): Challenges in the quest for Keystones. Bioscience 46: 609-620.

Rajan, K. Sreenivas and Pangarkar Nitin (2000) "Mode of entry choice: An empirical study of Singaporean multinationals" Asia Pacific Journal of Management, 17(1): 49.

Ramanathan K, 2007, An overview of technology transfer and technology transfer models

Ramanathan, K.(2007). The role of technology transfer services in technology capacity building and enhancing the competitiveness of SMEs. Mongolia National Workshop on "Subnational Innovation systems and Technology Capacity-building Policies to Enhance Competitiveness of SMEs." Organized by UN- ESCAP and ITMRC (Mongolia). Ulaanbaatar, Mongolia, 21-22 March.

Robinson, R., 1988. The International Transfer of Technology, Theory, Issues and Practice. Cambridge, MA: Ballinger.

Spivey, W., Munson, J., Nelson, M., Dietrich, G., 1997. "Coordinating the technology transfer and transition of information technology: a phenomenological perspective.| IEEE Transactions on Engineering Management 42 (1):,19-29

Teece, D. J, (1988) "Capturing value from technological innovation: integration, strategic partnering, and licensing decisions" Interfaces, 18(3): 46-61.

Terjesen, S., O'Gorman, C. \& Acs, Z.J. (2008). Intermediated mode of internationalization: new software ventures in Ireland and India. Entrepreneurship \& Regional Development, forthcoming.

Tse, D.K. \& Pan, Y. (2000), "The Hierarchical Model of Market Entry Modes", Journal of International Business Studies, 31 (Fourth Quarter): 535-554. 
UNCTAD (2004) Facilitating Transfer of Technology to Developing Countries: $A$ Survey of Home-Country Measures (UNCTAD/ITE/IPC/2004/5), Geneva:

UNCTAD

Van Schaik C.P.; Terborgh J.W \& Wright S.J. (1993) "The Phenology of tropical forest: Adaptive significance and consequences for primary consumers" Annual Review of Ecology and Systematic 24(5):353-377.

Westhead, P., Wright, M. \&Ucbasaran, D. (2002) "International market selection strategies selected by 'micro' and 'small' firms" Omega, 30(1), 51-68.

Woodcock, C. P.; Beamish,P.W. \& Makino,S. (1994) “Ownership-based entry mode strategies and intemational performance" Journal of International Business Studies, 25(2): 253-273. 


\section{Appendix}

\section{Appendix A : Coding for Sample A}

\begin{tabular}{|c|c|c|c|}
\hline Code & Code & $\begin{array}{c}\text { Data } \\
\text { Reference }\end{array}$ & Notes and Quotes from transcribed data \\
\hline Home Market & 1 & & $\begin{array}{l}\text { but we also do work out west and Atlantic } \\
\text { Canada }\end{array}$ \\
\hline Foreign market & 2 & & $\begin{array}{l}\text { that's where we see the real opportunities are } \\
\text { outside of Canada }\end{array}$ \\
\hline Market. Information & 3 & & $\begin{array}{l}\text { We've done some research into the } \\
\text { Caribbean, Latin America, and parts of Asia. }\end{array}$ \\
\hline Agents & 4 & & Knowing who to contact \\
\hline Local Agents & 5 & & getting the contacts in those areas \\
\hline Incumbents & 6 & & $\begin{array}{l}\text { people that have been dealing in those } \\
\text { markets }\end{array}$ \\
\hline Agents/intermediaries & 7 & & people who knows the market \\
\hline Market. Information & 8 & & $\begin{array}{l}\ldots \text { at this moment in time, and to determine } \\
\text { whether there are opportunities there }\end{array}$ \\
\hline Market. Information & 9 & & $\begin{array}{l}\text { the problem is actually trying to get that } \\
\text { information }\end{array}$ \\
\hline Informed Agents & 10 & & $\begin{array}{l}\text { I think the challenge is actually to locate who } \\
\text { that.. who really has got the information }\end{array}$ \\
\hline Market Knowledge & 11 & & $\begin{array}{l}\text { Who do you speak to? How do you know who } \\
\text { to speak to? }\end{array}$ \\
\hline Market information & 12 & & $\begin{array}{l}\text { somebody that will give you a focused } \\
\text { information that is relevant to your industry }\end{array}$ \\
\hline Market Knowledge & 13 & & $\begin{array}{l}\text { if you trying to run a business, and you got to } \\
\text { go through what these individual piece of } \\
\text { information, it could be quite a challenge }\end{array}$ \\
\hline Payment & 14 & & $\begin{array}{l}\text { my biggest concern with dealing with any } \\
\text { country outside of Canada is payment }\end{array}$ \\
\hline Market location & 15 & & $\begin{array}{l}\text { We do work that's } 10 \text { hours away from here.. } \\
\text { right? }\end{array}$ \\
\hline Payment & 16 & & My real concem is getting paid. \\
\hline Market Knowledge & 17 & & Cause you don't know who your customer is \\
\hline Bureaucracy & 18 & & $\begin{array}{l}\text { Obviously if you don't get paid, there are fairly } \\
\text { clearly defined way of seeking to seek that } \\
\text { payment right? }\end{array}$ \\
\hline Risk & 19 & & $\begin{array}{l}\text { If you don't get paid in foreign market, I don't } \\
\text { know , what happens .. what starts } \\
\text { happening... right? }\end{array}$ \\
\hline Govt. Services & 20 & & $\begin{array}{l}\text { And I think there is the EDC is certainly in a place } \\
\text { to help you with that }\end{array}$ \\
\hline
\end{tabular}




\section{Appendix A : Coding for Sample A}

\begin{tabular}{|c|c|c|c|}
\hline Code & Code & $\begin{array}{c}\text { Data } \\
\text { Reference } \\
\end{array}$ & Notes and Quotes from Transcribed data \\
\hline $\begin{array}{l}\text { Resource } \\
\text { constraint }\end{array}$ & 21 & & $\begin{array}{l}\text { Receivable is not a problem, it's a question of actually } \\
\text { receiving the receivable }\end{array}$ \\
\hline Trust & 22 & & $\begin{array}{l}\text { That's the overriding issue. Its trust, trust on the } \\
\text { customer base }\end{array}$ \\
\hline Payment & 23 & & Guaranteeing of payment \\
\hline $\begin{array}{l}\text { Market } \\
\text { information }\end{array}$ & 24 & & $\begin{array}{l}\text { good information.. focused information that leads } \\
\text { you to your right market }\end{array}$ \\
\hline Trust & 25 & & $\begin{array}{l}\text { then screened customer.. screened customer that } \\
\text { you can trust }\end{array}$ \\
\hline Services & 26 & & $\begin{array}{l}\text { if there is any legal framework that we need to put } \\
\text { in place }\end{array}$ \\
\hline Keystone & 27 & & That will be an interesting organization to speak to \\
\hline $\begin{array}{l}\text { Market } \\
\text { information }\end{array}$ & 28 & & I said the real problem is actually finding them \\
\hline $\begin{array}{l}\text { Market } \\
\text { Knowledge }\end{array}$ & 29 & & $\begin{array}{l}\text { they are using the solids for fertilizers for } \\
\text { farming and agriculture }\end{array}$ \\
\hline Product plus & 30 & & $\begin{array}{l}\text { you ending up with an agricultural product that } \\
\text { could be used }\end{array}$ \\
\hline $\begin{array}{l}\text { Market } \\
\text { information }\end{array}$ & 31 & & $\begin{array}{l}\text { Caribbean where the fertility of the soil is actually } \\
\text { very low }\end{array}$ \\
\hline Service Plus & 32 & & $\begin{array}{l}\text { You don't have these large lagoons that will sit there } \\
\text { and stink up to high heavens during the summer }\end{array}$ \\
\hline Resource & 33 & & the biggest cost is going to be man power \\
\hline Local Support & 34 & & $\begin{array}{l}\text { Caribbean areas and in Latin America as well, one } \\
\text { thing is that they have a lot of these labour and is } \\
\text { relatively cheap }\end{array}$ \\
\hline Simple Tech & 35 & & $\begin{array}{l}\text { it's a simple system, it's easy, the training can be very } \\
\text { easy }\end{array}$ \\
\hline $\begin{array}{l}\text { Absorptive } \\
\text { Capacity }\end{array}$ & 36 & & $\begin{array}{l}\text { it's a simple system, it's easy, the training can be } \\
\text { very easy }\end{array}$ \\
\hline Simple Tech & 37 & & $\begin{array}{l}\text { but to be honest with you, we've trained people } \\
\text { within half a day to be able to do the work }\end{array}$ \\
\hline
\end{tabular}




\section{Appendix B : Coding for Sample B}

\begin{tabular}{|c|c|c|c|}
\hline Code & Code & $\begin{array}{c}\text { Data } \\
\text { Reference }\end{array}$ & Notes and Quotes from transcribed data \\
\hline Foreign market & 1 & & We are into a little bit of international market \\
\hline Developing nation & 2 & & A little bit into Chile, Singapore and India \\
\hline Developing nation & 3 & & $\begin{array}{l}\text { We are prospecting into Nigeria and India in the } \\
\text { next } 12 \text { months }\end{array}$ \\
\hline Market link & 4 & & $\begin{array}{l}\text {...So sometimes its personal contacts, } \\
\text { networking, customers, we deal with } \\
\text { distributors, you know sales people }\end{array}$ \\
\hline $\begin{array}{l}\text { Local } \\
\text { representatives }\end{array}$ & 5 & & $\begin{array}{l}\text { We have even had many actual } \\
\text { representatives. .... }\end{array}$ \\
\hline Local presence & 6 & & $\begin{array}{l}\text {. . . for developing countries, the approach we } \\
\text { are going to take in the places like India, for } \\
\text { example, is to hire a local firm, to act as sort of } \\
\text { sales and technical representative. }\end{array}$ \\
\hline $\begin{array}{l}\text { Local } \\
\text { representative }\end{array}$ & 7 & & $\begin{array}{l}\text { we believe that to do a good job, you need } \\
\text { more than just a sales person, }\end{array}$ \\
\hline Market. Presence & 8 & & $\begin{array}{l}\text {... you often need a technical person in the } \\
\text { country who understands the country }\end{array}$ \\
\hline Uncertainty & 9 & & I do not know if that will work \\
\hline Memo 1 & & & $\begin{array}{l}\text { Owner not sure of if proposed market link will } \\
\text { work as planned }\end{array}$ \\
\hline Finance & 10 & & $\begin{array}{l}\text { our biggest challenges in those markets is } \\
\text { actually our own financing }\end{array}$ \\
\hline Process Delay & 11 & & $\begin{array}{l}\text { You have to be prepared, I think, to travel there, } \\
\text { to support the country and to go through a fairly } \\
\text { long time without revenue. }\end{array}$ \\
\hline Financial Constraint & 12 & & $\begin{array}{l}\text { You have to be willing to invest in the country } \\
\text { essentially, and we haven't had the finances to } \\
\text { do that. }\end{array}$ \\
\hline Funding & 13 & & $\begin{array}{l}\text { So we are just completing a new financing now, } \\
\text { and a, quite a lot of that, money we are raising } \\
\text { is actually going before getting into some of } \\
\text { these countries }\end{array}$ \\
\hline Access to funding & 14 & & $\begin{array}{l}\text { Usually negative... and especially for the } \\
\text { African markets, }\end{array}$ \\
\hline Memo 2 & & & $\begin{array}{l}\text { Investors are not favourably disposed to } \\
\text { funding the developing nation as a result of } \\
\text { their high risk perception of the market. }\end{array}$ \\
\hline
\end{tabular}




\section{Appendix B : Coding for Sample B (contd.)}

\begin{tabular}{|c|c|c|c|}
\hline Code & Code & $\begin{array}{c}\text { Data } \\
\text { Reference }\end{array}$ & Notes and Quotes from transcribed data \\
\hline Quality & 15 & & $\begin{array}{l}\text {... there is a feeling that the African markets } \\
\text { are better served by inferior quality products } \\
\text { from China, and I don't believe it! }\end{array}$ \\
\hline Funding & 16 & & $\begin{array}{l}\text { But a lot of our investors don't believe it. So it's } \\
\text { been difficult to raise money. }\end{array}$ \\
\hline Memo 3 & & & $\begin{array}{l}\text { Most investors are not disposed towards } \\
\text { funding the developing nations particularly } \\
\text { Africa. }\end{array}$ \\
\hline Average education & 17 & & $\begin{array}{l}\text { the advantage of our technology is that it requires } \\
\text { very little training }\end{array}$ \\
\hline Memo 4 & & & $\begin{array}{l}\text { Average level of education is good enough for the } \\
\text { transfer of the technology. }\end{array}$ \\
\hline Simple Tech & 18 & & $\begin{array}{l}\text { it should require less training than other battery } \\
\text { systems }\end{array}$ \\
\hline $\begin{array}{l}\text { Average } \\
\text { absorption }\end{array}$ & 19 & & $\begin{array}{l}\text { we don't have to do very much training on our } \\
\text { batteries itself }\end{array}$ \\
\hline Existing Market & 20 & & $\begin{array}{l}\text { It's not that our product stands-alone, our } \\
\text { product is, in many cases is going to replace } \\
\text { other battery systems. }\end{array}$ \\
\hline Existing Market & 21 & & $\begin{array}{l}\text { the people we are selling to is more of a } \\
\text { business to business relationship }\end{array}$ \\
\hline Education & 22 & & $\begin{array}{l}\text { we are dealing with people who have good } \\
\text { education }\end{array}$ \\
\hline Specialized Market & 23 & & $\begin{array}{l}\text { We are going to focus first on the larger market } \\
\text { telecommunications. }\end{array}$ \\
\hline Existing Market & 24 & & $\begin{array}{l}\text { to gain an existing market that some products } \\
\text { are in already, so it's a question of getting an } \\
\text { edge into the market place }\end{array}$ \\
\hline Market Rep & 25 & & $\begin{array}{l}\text { that's where hiring the right team in the country } \\
\text { is going to help us because they know, they } \\
\text { know the pain point }\end{array}$ \\
\hline Client's need & 26 & & $\begin{array}{l}\text { they know the pain that is been suffered by for } \\
\text { example the telecommunications company in } \\
\text { that country }\end{array}$ \\
\hline Agent/Intermediary & 27 & & $\begin{array}{l}\text { they can sell our product in those areas very } \\
\text { well because they can say I know this is your } \\
\text { pain }\end{array}$ \\
\hline Local Reps & 28 & & $\begin{array}{l}\text { And they can put it into words that are } \\
\text { understood by the people of the country } \\
\text { because they themselves are from the country. }\end{array}$ \\
\hline
\end{tabular}




\section{Appendix B : Coding for Sample B (contd.)}

\begin{tabular}{|c|c|c|c|}
\hline Code & Code & $\begin{array}{c}\text { Data } \\
\text { Reference }\end{array}$ & Notes and Quotes from transcribed data \\
\hline Home intermediary & 29 & & $\begin{array}{l}\text { Now we tend to target distributors in those } \\
\text { countries that have at least one or two people } \\
\text { who are educated with Canada or United } \\
\text { States so that they have a good idea of how } \\
\text { we work as well. So they can understand } \\
\text { both sides of the equation }\end{array}$ \\
\hline Agent/Reps & 30 & & $\begin{array}{l}\text { That is the biggest concern is that we have the } \\
\text { right representatives who can make sure that } \\
\text { our product is seen by the right people. }\end{array}$ \\
\hline Memo 5 & & & $\begin{array}{l}\text { Recruiting the right set of people as local rep } \\
\text { is the most challenging task for developing } \\
\text { nations. }\end{array}$ \\
\hline Market. Link & 31 & & $\begin{array}{l}\text { We've been looking for representatives... } \\
\text { emmm.. through networking, through word of } \\
\text { mouth, emmm through other companies that } \\
\text { we know have been successful }\end{array}$ \\
\hline Local presence & 32 & & $\begin{array}{l}\text { We knew of a company that had successfully } \\
\text { grown their sales in the Indian market, and, so } \\
\text { we went to that company and said how did you } \\
\text { do it? }\end{array}$ \\
\hline Local presence & 33 & & $\begin{array}{l}\text { We have located a company that we think we } \\
\text { will be very happy with. }\end{array}$ \\
\hline Local regulation & 34 & & $\begin{array}{l}\text { the reasons that India is one of the first } \\
\text { countries we are targeting is because they are } \\
\text { passing legislation that will change the way the } \\
\text { telecommunications operators will have to } \\
\text { operate their towers }\end{array}$ \\
\hline Market information & 35 & & $\begin{array}{l}\text { Right now, } 1.2 \text { billion litres of diesel is burnt } \\
\text { every year powering generators that run the } \\
\text { cell phone towers in India. So the government } \\
\text { is passing legislation to make that illegal. So, } \\
\text { the telecoms operators must get their towers } \\
\text { to run of either grid energy or solar energy or } \\
\text { wind energy }\end{array}$ \\
\hline $\begin{array}{l}\text { Favourable } \\
\text { legislation }\end{array}$ & 36 & & $\begin{array}{l}\text { So obviously that legislation been passed has } \\
\text { been a huge help to us, and to make it even } \\
\text { better, the government in India is reducing the } \\
\text { tax on renewable energy systems that are } \\
\text { been imported into India specifically for } \\
\text { telecommunications }\end{array}$ \\
\hline
\end{tabular}




\section{Appendix B : Coding for Sample B (contd.)}

\begin{tabular}{|c|c|c|c|}
\hline Code & Code & $\begin{array}{c}\text { Data } \\
\text { Reference }\end{array}$ & Notes and Quotes from transcribed data \\
\hline Memo 6 & & & $\begin{array}{l}\text { Where favourable local legislation exist, } \\
\text { market entry becomes easier. }\end{array}$ \\
\hline $\begin{array}{l}\text { Favourable Home } \\
\text { Govt }\end{array}$ & 37 & & $\begin{array}{l}\text { EDC) will provide funding to the companies in } \\
\text { these developing nations specifically so they } \\
\text { can buy our product. }\end{array}$ \\
\hline Govt. Funding & 38 & & $\begin{array}{l}\text { The Canadian government would loan the } \\
\text { company in Chile the money which then that } \\
\text { company would in turn, then buy the batteries } \\
\text { from us. }\end{array}$ \\
\hline Memo 7 & & & $\begin{array}{l}\text { Home government funding aid small coy.s in } \\
\text { their TT effort. }\end{array}$ \\
\hline Payment & 39 & & $\begin{array}{l}\text { they are companies that already have good } \\
\text { strong revenue track records. }\end{array}$ \\
\hline Risks & 40 & & $\begin{array}{l}\text { there was one company that wants us to } \\
\text { finance them that way and we couldn't, they } \\
\text { had no revenues, no track record and I really } \\
\text { couldn't blame EDC for not wanting to } \\
\text { finance them }\end{array}$ \\
\hline Risks & 41 & & $\begin{array}{l}\text { if the market carries a substantial level of } \\
\text { risk, financing might become a little bit of a } \\
\text { challenge. }\end{array}$ \\
\hline Finance & 42 & & $\begin{array}{l}\text { if the market carries a substantial level of } \\
\text { risk, financing might become a little bit of a } \\
\text { challenge. }\end{array}$ \\
\hline Unstable Govt. & 43 & & $\begin{array}{l}\text { I do have concern with government, and } \\
\text { again, that's where I need to trust the } \\
\text { company that we hire in those countries, I } \\
\text { need to trust them to understand the risk, to } \\
\text { tell me about the risk and help mitigate the } \\
\text { risk }\end{array}$ \\
\hline Memo 8 & & & $\begin{array}{l}\text { Unstable government only translate to risk. If } \\
\text { risk can be managed, this coy. Is ready to } \\
\text { proceed. }\end{array}$ \\
\hline Risk Tolerance & 44 & & $\begin{array}{l}\text { Because even if there is unrest, it doesn't } \\
\text { always mean that no business can happen in } \\
\text { the country }\end{array}$ \\
\hline Local Reps. & 45 & & $\begin{array}{l}\text { So, I think that we are having people on the } \\
\text { ground from the country from that country } \\
\text { really helps because they are there }\end{array}$ \\
\hline
\end{tabular}




\begin{tabular}{|c|c|c|c|}
\hline Code & Code & $\begin{array}{c}\text { Data } \\
\text { Reference }\end{array}$ & Notes and Quotes from transcribed data \\
\hline $\begin{array}{l}\text { Availability of } \\
\text { Resources }\end{array}$ & 46 & & $\begin{array}{l}\text {..... . called CCC eeee which helps with the } \\
\text { military side of things... so if I want to sell to a } \\
\text { military organization, they do a lot of the } \\
\text { same things, they will help fund guarantee } \\
\text { contracts, things like that. }\end{array}$ \\
\hline Keystone & 47 & & $\begin{array}{l}\ldots . . . \text { Then yes we would work with them. } \\
\text { That's what we are doing now in India, you } \\
\text { just described what the Indian company is }\end{array}$ \\
\hline
\end{tabular}




\section{Appendix C: Coding for Sample C}

\begin{tabular}{|c|c|c|c|}
\hline Code & Code & $\begin{array}{c}\text { Data } \\
\text { Reference }\end{array}$ & Notes and Quotes from transcribed data \\
\hline Power Generation & 1 & & $\begin{array}{l}\text { Energy /clean tech sector (power generation) } \\
\text { and Client specific market (Farmers) }\end{array}$ \\
\hline Gas Production & 2 & & Clean Tech industry \\
\hline Mixed Market & 3 & & $\begin{array}{l}\text { Market appeal to developed nations. Operates } \\
\text { locally and in the U.S }\end{array}$ \\
\hline Open Infor. Session & 4 & & $\begin{array}{l}\text { Relatively new tech, market information } \\
\text { disseminated and collected through } \\
\text { conferences and info session }\end{array}$ \\
\hline Personal Networking & 5 & & $\begin{array}{l}80 \% \text { market information through personal } \\
\text { contacts (the tech addresses a small market } \\
\text { niche }\end{array}$ \\
\hline Market Knowledge & 6 & & $\begin{array}{l}\text { Posses market knowledge of the South } \\
\text { Americas and Brazil }\end{array}$ \\
\hline Unique Tech & 7 & & $\begin{array}{l}\text { Limited player in the use of Tech (by } \\
\text { implication Oligopolistic in nature?) }\end{array}$ \\
\hline Functional Tech & 8 & & $\begin{array}{l}\text { Tested, validated and functional Technology } \\
\text { with organization (something that works) }\end{array}$ \\
\hline Location Factor & 9 & & $\begin{array}{l}\text { Technology relevant to the farmers or farm } \\
\text { dominated regions }\end{array}$ \\
\hline Market Reference & 10 & & $\begin{array}{l}\text { Owners of problem got referenced to Tech } \\
\text { source (Not many in the trade?) }\end{array}$ \\
\hline Unique Market & 11 & & Always a niche market, not widely spread \\
\hline Viability & 12 & & Economic viability determines the project \\
\hline Protocol/Procedure & 13 & & $\begin{array}{l}\text { Power generation requires lots of permit and } \\
\text { consequently not many are willing to persevere }\end{array}$ \\
\hline Tech Absorption & 14 & & $\begin{array}{l}\text { Capacity to understand and operate } \\
\text { technology is of concern }\end{array}$ \\
\hline Incompatible/Indirect & 15 & & $\begin{array}{l}\text { One time indirect approach failed because } \\
\text { third part have little or no knowledge of } \\
\text { Technology }\end{array}$ \\
\hline Memo 1 & & & $\begin{array}{l}\text { The knowledge of the product is key determinant in } \\
\text { choice of direct or indirect. Indirect with lack in } \\
\text { knowledge of product may always lead transfer } \\
\text { failure! }\end{array}$ \\
\hline
\end{tabular}




\section{Appendix C: Coding for Sample C (contd.)}

\begin{tabular}{|c|c|c|c|}
\hline Code & Code & $\begin{array}{c}\text { Data } \\
\text { Reference }\end{array}$ & Notes and Quotes from transcribed data \\
\hline Specialized Tech & 16 & & $\begin{array}{l}\text { Knowledge of Tech not quite prevalent in the } \\
\text { market and this led to indirect link failure }\end{array}$ \\
\hline Memo 2 & & & Client associate success with direct transfer! \\
\hline Memo 3 & & & $\begin{array}{l}\text { Procedure constraints determines the choice } \\
\text { of direct or indirect tech transfer }\end{array}$ \\
\hline Memo 4 & & & $\begin{array}{l}\text { Direct transfer could be influence where the project } \\
\text { is a one time process where cost incurred can be } \\
\text { pass on to the client. It is a client request-base tech } \\
\text { transfer. In addition no after installation } \\
\text { maintenance or compulsory follow up }\end{array}$ \\
\hline Memo 5 & & & $\begin{array}{l}\text { Bureaucratic perception of government } \\
\text { policies and their agencies. }\end{array}$ \\
\hline Resource Constraint & 18 & & $\begin{array}{l}\text { no in house staff nor resources to keep the } \\
\text { level of staff required to relate with EDC }\end{array}$ \\
\hline Locally Established & 19 & & $\begin{array}{l}\text { Thriving quite well locally with little presence } \\
\text { abroad }\end{array}$ \\
\hline Market Information & 20 & & $\begin{array}{l}\text { Related trade operator referred clients for } \\
\text { Chile Market }\end{array}$ \\
\hline Local Link & 21 & & Market link to developing nation \\
\hline $\begin{array}{l}\text { Regulated } \\
\text { environment }\end{array}$ & 22 & & $\begin{array}{l}\text { Compels the use of local market link, not } \\
\text { necessarily an agent }\end{array}$ \\
\hline Memo 6 & & & $\begin{array}{l}\text { Highly regulated environment is related to choice of } \\
\text { direct/indirect market access. Home linked or target } \\
\text { market linked }\end{array}$ \\
\hline Memo 7 & & & $\begin{array}{l}\text { So pretty much it is the complexity involve and } \\
\text { the level of your technology that determines } \\
\text { the method that you engage i.e direct or } \\
\text { indirect }\end{array}$ \\
\hline Resource Constraint & 23 & & $\begin{array}{l}\text { We have to remain focused on areas of } \\
\text { comfort as against going after new market for } \\
\text { which we are not too sure of }\end{array}$ \\
\hline Memo 8 & & & $\begin{array}{l}\text { Resource constraints: You are just by yourself } \\
\text { and you can only do so much }\end{array}$ \\
\hline
\end{tabular}




\section{Appendix D : Coding for Sample D}

\begin{tabular}{|c|c|c|c|}
\hline Code & Code & $\begin{array}{c}\text { Data } \\
\text { Reference }\end{array}$ & Notes and Quotes from transcribed data \\
\hline Power Generation & 1 & & $\begin{array}{l}\text { Creative solutions for renewable energy; } \\
\text { basically production or generation of } \\
\text { energy, conservation of energy and } \\
\text { management of energy }\end{array}$ \\
\hline Partnership & 3 & & $\begin{array}{l}\text { Partnering with similar organisation in the } \\
\text { industry to take product to market }\end{array}$ \\
\hline Keystone Function & 3 & & $\begin{array}{l}\text { Harnessing the strength of forming } \\
\text { Consortium to access the market place }\end{array}$ \\
\hline Focused Market & 4 & & $\begin{array}{l}\text { Our target market is focussed toward the } \\
\text { end users }\end{array}$ \\
\hline Memo 1 & & & $\begin{array}{l}\text { Focused target of this renewable energy } \\
\text { coy is the developing nations. Most of her } \\
\text { approach is basically indirect through } \\
\text { formation of consortium }\end{array}$ \\
\hline Market Knowledge & 5 & & $\begin{array}{l}\text { Presently our market knowledge is limited } \\
\text { to internal sphere. But now we know there } \\
\text { are opportunities out there }\end{array}$ \\
\hline Market Agents & 6 & & $\begin{array}{l}\text { We need people from the various } \\
\text { Countries to give us information of their } \\
\text { market }\end{array}$ \\
\hline Market Knowledge & 7 & & $\begin{array}{l}\text { Experience in the target market and with } \\
\text { good understanding of the market }\end{array}$ \\
\hline Cost of Alternative & 8 & & Existing cost of energy in the target market \\
\hline Quality Alternative & 9 & & $\begin{array}{l}\text { Proposed energy is clean and } \\
\text { environmentally friendly and good for high } \\
\text { tech equipment }\end{array}$ \\
\hline Payback Period & 10 & & $\begin{array}{l}\text { The current high cost of energy present a } \\
\text { faster payback period }\end{array}$ \\
\hline Product Reliability & 11 & & $\begin{array}{l}\text { Product with low maintenance and yet } \\
\text { serving the need of the target market }\end{array}$ \\
\hline Market Agents & 12 & & $\begin{array}{l}\text { We need the right people to connect us } \\
\text { into this market }\end{array}$ \\
\hline $\begin{array}{l}\text { Resource } \\
\text { Constraint }\end{array}$ & 13 & & $\begin{array}{l}\text { Financial constraints to finance the } \\
\text { marketing of the target market }\end{array}$ \\
\hline Limited Capacity & 14 & & $\begin{array}{l}\text { We can provide sufficient man-hour but we } \\
\text { need fund to move to the next level }\end{array}$ \\
\hline Cost of Transfer & 15 & & $\begin{array}{l}\text { We cannot afford to provide training in our } \\
\text { target market. The cost is too high }\end{array}$ \\
\hline $\begin{array}{l}\text { Resource } \\
\text { Constraint }\end{array}$ & 16 & & $\begin{array}{l}\text { We need to have people on ground in the } \\
\text { target market, but we cannot afford that }\end{array}$ \\
\hline
\end{tabular}




\section{Appendix D : Coding for Sample D (contd.)}

\begin{tabular}{|c|c|c|c|}
\hline Code & Code & $\begin{array}{c}\text { Data } \\
\text { Reference } \\
\end{array}$ & $\begin{array}{l}\text { Notes and Quotes from transcribed } \\
\text { data }\end{array}$ \\
\hline $\begin{array}{l}\text { Manufacturer } \\
\text { Focused }\end{array}$ & 17 & & $\begin{array}{l}\text { Government aid is mfct focused, and we } \\
\text { do not get as much assistance }\end{array}$ \\
\hline Market information & 18 & & $\begin{array}{l}\text { Information of existing market are scarce. } \\
\text { We need more market information }\end{array}$ \\
\hline Market Link & 19 & & $\begin{array}{l}\text { We have no clue of the market and we need } \\
\text { those who can link us into this developing } \\
\text { nations }\end{array}$ \\
\hline Market Penetration & 20 & & $\begin{array}{l}\text { Our link to the existing network has to } \\
\text { improve }\end{array}$ \\
\hline Market Penetration & 21 & & Getting the product to the people \\
\hline Capital constraint & 22 & & $\begin{array}{l}\text { We cannot provide the necessary funding } \\
\text { for all we have to do }\end{array}$ \\
\hline $\begin{array}{l}\text { Keystone } \\
\text { Organisation } \\
\end{array}$ & 23 & & $\begin{array}{l}\text { bring together the various team leaders in } \\
\text { the higher levels, the government, the } \\
\text { EDC level etc. That's missing ingredient }\end{array}$ \\
\hline Financial Resources & 24 & & $\begin{array}{l}\text { Grants or any financial aid will be required } \\
\text { to move on to this market }\end{array}$ \\
\hline Technology Base & 25 & & Our product is highly technical \\
\hline Tech-Keystone Org. & 26 & & $\begin{array}{l}\text { An organisation that is technically oriented } \\
\text { and that can harness the various function } \\
\text { will be welcome }\end{array}$ \\
\hline Proprietary Control & 27 & & $\begin{array}{l}\text { We want to retain the control of our product } \\
\text { and process (for proprietary reason) }\end{array}$ \\
\hline Memo 2 & & & $\begin{array}{l}\text { Case study is already prospecting an } \\
\text { organization that provide services similar to } \\
\text { that of a Keystone organization }\end{array}$ \\
\hline $\begin{array}{l}\text { Existing Keystone } \\
\text { Org }\end{array}$ & 28 & & $\begin{array}{l}\text { We work with an organisation that acts as } \\
\text { center for all to collaborate and its } \\
\text { promising }\end{array}$ \\
\hline
\end{tabular}




\section{Appendix E : Coding for Sample E}

\begin{tabular}{|c|c|c|c|}
\hline Code & Code & $\begin{array}{c}\text { Data } \\
\text { Reference }\end{array}$ & Notes and Quotes from transcribed data \\
\hline Energy & 1 & & $\begin{array}{l}\text { interested in alternative energy, renewable } \\
\text { energy, energy conservation }\end{array}$ \\
\hline Size & 2 & & We are a small company in a big industry \\
\hline Local Market & 3 & & $\begin{array}{l}60 \text { dealers across Canada that sell Glen energy } \\
\text { brand lighting products }\end{array}$ \\
\hline Service & 4 & & our real mission which is to bring light to people \\
\hline Developing Market & 5 & & we are also active in central America \\
\hline Market. Information & 6 & & $\begin{array}{l}\text { We need to be able to interview our customer, } \\
\text { end user - client and from that extract what } \\
\text { their needs are, analyse those needs }\end{array}$ \\
\hline Market. Link & 7 & & $\begin{array}{l}\text { we can't sell in African villages from here, and } \\
\text { not directly, we can perhaps identify } \\
\text { entrepreneur candidates }\end{array}$ \\
\hline Market. Reps & 8 & & $\begin{array}{l}\text { standard model is to identify an entrepreneur, } \\
\text { who may be an individual, who may be a women } \\
\text { group, who may a be a church group, who may } \\
\text { be school, from a business point }\end{array}$ \\
\hline Education & 9 & & $\begin{array}{l}\text { if we have that entrepreneur who gains } \\
\text { knowledge and skill in science systems or have } \\
\text { had interact with us for our support }\end{array}$ \\
\hline $\begin{array}{l}\text { Market. } \\
\text { Intermediary }\end{array}$ & 10 & & $\begin{array}{l}\text { What we're looking at right now, is, I have } \\
\text { emmmm, the title is variable, but say } \\
\text { international business development office }\end{array}$ \\
\hline Infrastructure & 11 & & $\begin{array}{l}\text { transportation from Dar es Salaam to the rest of } \\
\text { east Africa now is convenient .. so we going to } \\
\text { setup there and that will be our principle } \\
\text { warehousing distribution }\end{array}$ \\
\hline Local Agent & 12 & & $\begin{array}{l}\text { I can't do that by email, not find a partner } \\
\text { anyway, emmm, so have been } 6 \text { times to Africa, } \\
\text { I'm going my } 7^{\text {th }}\end{array}$ \\
\hline $\begin{array}{l}\text { Market. } \\
\text { Sustenance }\end{array}$ & 13 & & visiting with some of our entrepreneurs \\
\hline $\begin{array}{l}\text { Market. } \\
\text { Maintenance }\end{array}$ & 14 & & $\begin{array}{l}\text { we have } 5 \text { villages that we are visiting, } 5 \\
\text { projects, } 2 \text { brown new that we will be setting up } \\
\text { and } 3 \text { that we are checking to see how it's going, }\end{array}$ \\
\hline Local Agents & 15 & & $\begin{array}{l}\text { We need intermediaries; we need people to be } \\
\text { local }\end{array}$ \\
\hline Local Reps & 16 & & $\begin{array}{l}\text { So what we do, is, I mentioned look for entrepreneurs } \\
\text { and qualify them }\end{array}$ \\
\hline
\end{tabular}




\section{Appendix E : Coding for Sample E (contd.)}

\begin{tabular}{|c|c|c|c|}
\hline Code & Code & $\begin{array}{c}\text { Data } \\
\text { Reference } \\
\end{array}$ & Notes and Quotes from transcribed data \\
\hline Local Agents & 17 & & $\begin{array}{l}\text { what we are looking for is people who are in } \\
\text { Uganda say, who want to be involved in the } \\
\text { solar business }\end{array}$ \\
\hline Recruitment & 18 & & $\begin{array}{l}\text { so people who have an interest in some part of } \\
\text { what we are doing, can read about our process } \\
\text { fill out a form, then respond to a series of email } \\
\text { from us }\end{array}$ \\
\hline Education & 19 & & $\begin{array}{l}\text { have to speak English, or they are not going to } \\
\text { be responding..... They have to be } \\
\text { computer literate... }\end{array}$ \\
\hline Venture sharing & 20 & & $\begin{array}{l}\text { we get a share and they get a share, until the } \\
\text { system is paid for and then it's theirs. }\end{array}$ \\
\hline Cash flow & 21 & & $\begin{array}{l}\text { because the money comes back very slowly } \\
\text { and the initial capitalization is large }\end{array}$ \\
\hline Finance & 22 & & $\begin{array}{l}\text { Cause the financing hump is, for me is the } \\
\text { biggest }\end{array}$ \\
\hline Leverage & 23 & & $\begin{array}{l}\text { that one of the ways to helps us keep our } \\
\text { pipeline full is to work with an NGO here }\end{array}$ \\
\hline $\begin{array}{l}\text { Resource } \\
\text { constraint }\end{array}$ & 24 & & $\begin{array}{l}\text { if we can develop local reps more easily or } \\
\text { better train our entrepreneurs in technical sales } \\
\text { while preparing and exercising things }\end{array}$ \\
\hline $\begin{array}{l}\text { Absorptive } \\
\text { Capacity }\end{array}$ & 25 & & $\begin{array}{l}\text { But those are remarkable difficult concepts to } \\
\text { get across when you don't know the literacy of } \\
\text { the recipient }\end{array}$ \\
\hline Market information & 26 & & $\begin{array}{l}\text { How many tones of carbon dioxide are not } \\
\text { getting released, those are every bit as } \\
\text { important for the board to report to the } \\
\text { shareholders }\end{array}$ \\
\hline Foreign production & 27 & & $\begin{array}{l}\text { it's like you do not produce them in Canada, } \\
\text { you produce them outside of Canada and then } \\
\text { ship them to destination }\end{array}$ \\
\hline Legislation & 28 & & $\begin{array}{l}\text { to have zero tariffs on solar lighting products } \\
\text { which is a huge help. }\end{array}$ \\
\hline
\end{tabular}




\section{Appendix F : Coding for Sample F}

\begin{tabular}{|c|c|c|c|}
\hline Code & Code & $\begin{array}{c}\text { Data } \\
\text { Reference } \\
\end{array}$ & Notes and Quotes from transcribed data \\
\hline Energy Sector & 1 & & Generating electricity from garbage dumb \\
\hline Enhanced product & 2 & & Additional product such as natural gas etc \\
\hline Developed Market & 3 & & $\begin{array}{l}\text { Market potential are mainly in the developed } \\
\text { economy }\end{array}$ \\
\hline $\begin{array}{l}\text { Prod. Deter. } \\
\text { Market }\end{array}$ & 4 & & $\begin{array}{l}\text { The nature of this product determines its market. } \\
\text { The process is of high tech which can only be } \\
\text { supported in the developed economy }\end{array}$ \\
\hline Existing Cost & 5 & & $\begin{array}{l}\text { Current cost of dumping garbage plays a major } \\
\text { role in our analysis of the target market }\end{array}$ \\
\hline Prod. Existing cost & 6 & & $\begin{array}{l}\text { Local cost of power determines the viability of } \\
\text { our product in the target market. }\end{array}$ \\
\hline Location & 7 & & $\begin{array}{l}\text { Global regional price of energy influence our } \\
\text { choice of market }\end{array}$ \\
\hline Memo 1 & & & $\begin{array}{l}\text { Regional factors determines prospect for foreign } \\
\text { market }\end{array}$ \\
\hline Existing Cost & 8 & & $\begin{array}{l}\text { Total cost of generating energy within the target } \\
\text { market is a factor that influence final investment } \\
\text { decision }\end{array}$ \\
\hline $\begin{array}{l}\text { Absorptive } \\
\text { Capacity }\end{array}$ & 9 & & $\begin{array}{l}\text { Is the target market ready for the new } \\
\text { technology? }\end{array}$ \\
\hline Local Adaptation & 10 & & $\begin{array}{l}\text { Is the local market ready for the major shift from } \\
\text { current practice of land fill to recycling and } \\
\text { energy generation }\end{array}$ \\
\hline New Technology & 11 & & $\begin{array}{l}\text { It is a relatively new Tech as such market must } \\
\text { be well developed to support the project }\end{array}$ \\
\hline R\&D & 12 & & $\begin{array}{l}\text { We have research team in place that investigate } \\
\text { the market to determine the direction to go }\end{array}$ \\
\hline Memo 2 & & & $\begin{array}{l}\text { Where there is a well established Market R\&D, } \\
\text { specific market information are readily obtained }\end{array}$ \\
\hline Market Prospect & 13 & & $\begin{array}{l}\text { For any prospective market that attract our } \\
\text { interest, we go for it }\end{array}$ \\
\hline Memo 3 & & & $\begin{array}{l}\text { Market prospect could determine the use of } \\
\text { Agents }\end{array}$ \\
\hline Local Agents & 14 & & $\begin{array}{l}\text { We do hire some local agent to assist in the target } \\
\text { market }\end{array}$ \\
\hline Consultant Agents & 15 & & $\begin{array}{l}\text { we work with local consultants to develop the } \\
\text { various opportunities }\end{array}$ \\
\hline
\end{tabular}




\section{Appendix F : Coding for Sample F (contd.)}

\begin{tabular}{|c|c|c|c|}
\hline Code & Code & $\begin{array}{c}\text { Data } \\
\text { Reference }\end{array}$ & Notes and Quotes from transcribed data \\
\hline $\begin{array}{l}\text { Location } \\
\text { Information }\end{array}$ & 16 & & $\begin{array}{l}\text { We need this consultant to assist to determine the } \\
\text { Cities and towns that are ready for the Technology }\end{array}$ \\
\hline Resources & 17 & & Private investors \\
\hline $\begin{array}{l}\text { Leveraged } \\
\text { Resources } \\
\end{array}$ & 18 & & $\begin{array}{l}\text { Internally sourced investors are used to finance } \\
\text { project and Angel investors too }\end{array}$ \\
\hline Memo 4 & & & $\begin{array}{l}\text { Direct transfer of technology is highly influenced by } \\
\text { the availability of investors fund that could be } \\
\text { leveraged by the SSE }\end{array}$ \\
\hline $\begin{array}{l}\text { Complex } \\
\text { Technology }\end{array}$ & 19 & & $\begin{array}{l}\text { At this stage of our technology, the developing } \\
\text { nations are not ready }\end{array}$ \\
\hline $\begin{array}{l}\text { Absorptive } \\
\text { Capacity }\end{array}$ & 20 & & $\begin{array}{l}\text { Developing nations are obviously not ready for this } \\
\text { product. They are not ready at this time }\end{array}$ \\
\hline Market Viability & 21 & & $\begin{array}{l}\text { Organization has assessed developing nation as } \\
\text { not viable for her technology " Fate determined" }\end{array}$ \\
\hline Business Model & 22 & & $\begin{array}{l}\text { Business model of "finance, build, own and } \\
\text { operate" is highly Direct market entry oriented }\end{array}$ \\
\hline FDI Oriented & 23 & & Business model designed to do FDI \\
\hline FDI Oriented & 24 & & Essentially the practice is to own the facility \\
\hline Skill Development & 25 & & $\begin{array}{l}\text { We train local employees to operate plant: } \\
\text { Technology absorptive capacity is essential for } \\
\text { market to qualify }\end{array}$ \\
\hline Memo 5 & & & $\begin{array}{l}\text { SSE in FDI is influenced by their access to } \\
\text { financial resources. }\end{array}$ \\
\hline Age & 26 & & $\begin{array}{l}\text { Old SSEs sometimes develop the capacity of big } \\
\text { organization over a long period of time }\end{array}$ \\
\hline Memo 6 & & & $\begin{array}{l}\text { Check for age influence in decision to go direct or } \\
\text { indirect. How much influence does age has on } \\
\text { resource availability? }\end{array}$ \\
\hline New Technology & 27 & & $\begin{array}{l}\text { Access to the market have met with the challenge } \\
\text { of it being a new technology }\end{array}$ \\
\hline New Tech Risks & 28 & & $\begin{array}{l}\text { There is always a risk of the first timer accepting } \\
\text { new tech. Hence our challenge of penetrating the } \\
\text { market }\end{array}$ \\
\hline New Tech & 29 & & $\begin{array}{l}\text { No community wants to be the first, Nobody wants } \\
\text { to be the "guinea pig" }\end{array}$ \\
\hline Memo 7 & & & $\begin{array}{l}\text { New tech and associated risk is influential to direct } \\
\text { or indirect approach. Potential client need to be } \\
\text { convinced hence the need for FDI approach of } \\
\text { some SSE? }\end{array}$ \\
\hline
\end{tabular}




\section{Appendix F : Coding for Sample F (contd.)}

\begin{tabular}{|c|c|c|c|}
\hline Code & Code & $\begin{array}{c}\text { Data } \\
\text { Reference }\end{array}$ & Notes and Quotes from transcribed data \\
\hline Established Tech & 30 & & $\begin{array}{l}\text { Tested technology receive prompt } \\
\text { acceptance unlike the new Technology as in } \\
\text { this case }\end{array}$ \\
\hline Absorptive Ability & 31 & & $\begin{array}{l}\text { Coy team goes to target to train personal in } \\
\text { the target market ahead of take off. }\end{array}$ \\
\hline Keystone function & 32 & & $\begin{array}{l}\text { Policy definition and certification exercise } \\
\text { can be contracted out to a second party who } \\
\text { know s the market and the player }\end{array}$ \\
\hline Market interest & 33 & & $\begin{array}{l}\text { Developed markets that have interest in our } \\
\text { product are our current focus at this time. No } \\
\text { interest in any developing economy }\end{array}$ \\
\hline Memo 8 & & & $\begin{array}{l}\text { Naturally altractive technology may not need } \\
\text { leveraging to access market of interest. } \\
\text { Interest group/market may facilitate direct } \\
\text { tech transfer }\end{array}$ \\
\hline Prerequisite & 34 & & $\begin{array}{l}\text { Target market have to adopt a new waste } \\
\text { management rules and guidelines before } \\
\text { Technology come main stream }\end{array}$ \\
\hline Unique Market Factor & 35 & & $\begin{array}{l}\text { Where target market is currently seeking an } \\
\text { alternative solution to their waste } \\
\text { management, it becomes a unique factor for } \\
\text { us to come in. }\end{array}$ \\
\hline Tech Appeal & 36 & & $\begin{array}{l}\text { Some of the market we are working on have } \\
\text { natural flea for our Technology and that is } \\
\text { where are focused now }\end{array}$ \\
\hline Client initiated Project & 37 & & $\begin{array}{l}\text { The initial contact to Poland is an enquiry by } \\
\text { the client herself. We sent our team to } \\
\text { investigate }\end{array}$ \\
\hline Validation & 38 & & $\begin{array}{l}\text { Government letters of validation and } \\
\text { government use of our Technology is a } \\
\text { great plus for us to penetrate the foreign } \\
\text { market }\end{array}$ \\
\hline $\begin{array}{l}\text { Implementation } \\
\text { Duration }\end{array}$ & 39 & & $\begin{array}{l}\text { It takes about three years to implement a project } \\
\text { (though, this is size dependent) }\end{array}$ \\
\hline Memo 9 & & & $\begin{array}{l}\text { Project implementation period can influence } \\
\text { direct/indirect }\end{array}$ \\
\hline
\end{tabular}




\section{Appendix G : Coding for Sample G}

\begin{tabular}{|c|c|c|c|}
\hline Code & Code & $\begin{array}{c}\text { Data } \\
\text { Reference }\end{array}$ & Notes and Quotes from transcribed data \\
\hline Energy Sector & 1 & & $\begin{array}{l}\text { Power distribution equipment for Power } \\
\text { generation industries }\end{array}$ \\
\hline Unique Product & 2 & & Customized product for specific market use \\
\hline Unique Tech & 3 & & $\begin{array}{l}\text { Differentiated application of technology not } \\
\text { available on mass production line }\end{array}$ \\
\hline Design Constraint & 3B & & $\begin{array}{l}\text { NIS Design standard leading to market (user) } \\
\text { constraint }\end{array}$ \\
\hline Memo 1 & & & $\begin{array}{l}\text { Standard differentiated market place a } \\
\text { constraint on extent of spread in the market } \\
\text { place }\end{array}$ \\
\hline Market Constraint & 4 & & That limits us in the market place i.e standard \\
\hline Developing Market & 5 & & $\begin{array}{l}\text { Product appeals to developing market due to } \\
\text { lack of standards in such market }\end{array}$ \\
\hline Experienced Exporter & 6 & & $\begin{array}{l}\text { SC's experience in the market place informs } \\
\text { their wiliness to embark more on exportation }\end{array}$ \\
\hline Past Reference & 7 & & $\begin{array}{l}\text { Market insights as a result of references on } \\
\text { completed jobs/exportation }\end{array}$ \\
\hline Experience indirect. & 8 & & Remote reference on completed jobs \\
\hline Unique Requirement & 9 & & $\begin{array}{l}\text { Specific client requirement that demand for } \\
\text { supplier's specific product }\end{array}$ \\
\hline Low Tech Absorption & 10 & & $\begin{array}{l}\text { Low skilled and averagely educated target } \\
\text { market operators defines direct or indirect } \\
\text { approach. It may sometimes require the use of } \\
\text { larger companies that has its presence in the } \\
\text { target market to provide necessary trainings }\end{array}$ \\
\hline Memo 2 & & & $\begin{array}{l}\text { Uniqueness of product results into large } \\
\text { market in the developing economy where tech } \\
\text { absorptive capacity is relatively low }\end{array}$ \\
\hline Prod. Base Sales Point & 11 & & $\begin{array}{l}\text { Unique product influence the willingness of } \\
\text { MNE to take product to the market }\end{array}$ \\
\hline Prototype Cost & 12 & & $\begin{array}{l}\mathrm{SC} \text { was willing to bear the cost of prototype } \\
\text { because of the involvement of MNE to the } \\
\text { market place }\end{array}$ \\
\hline Payment & 13 & & $\begin{array}{l}S C \text { was willing to go to any market through } \\
\text { any route that guarantees payment }\end{array}$ \\
\hline Resource Constraint & 14 & & $\begin{array}{l}\text { Payment is critical to us. Exporting abroad can } \\
\text { drain our resources, hence the reason for } \\
\text { security of payment }\end{array}$ \\
\hline
\end{tabular}




\section{Appendix G : Coding for Sample G (Contd.)}

\begin{tabular}{|c|c|c|c|}
\hline Code & Code & $\begin{array}{c}\text { Data } \\
\text { Reference }\end{array}$ & Notes and Quotes from transcribed data \\
\hline Memo 3 & & & $\begin{array}{l}\text { Payment security is highly influential in the bid } \\
\text { for developing market opportunity. } \\
\text { Oftentimes, it dictate indirect transfer }\end{array}$ \\
\hline Market indicators/index & 15 & & $\begin{array}{l}\text { To launch into the market, directly or } \\
\text { indirectly: economic factors, sociological and } \\
\text { technological factors in the market place are } \\
\text { relevant in the decision process }\end{array}$ \\
\hline Risk & 16 & & $\begin{array}{l}\text { Risk and level of exposure in terms of } \\
\text { vulnerability, security and safety }\end{array}$ \\
\hline Product Size & 17 & & $\begin{array}{l}\text { Shipping cost is not cheap for large items. } \\
\text { Associated logistics of shipping large items } \\
\text { can be discouraging for uncertain market }\end{array}$ \\
\hline Market Distance & 18 & & $\begin{array}{l}\text { When product is likely irretrievable mainly due } \\
\text { to market distance, then you want to go } \\
\text { through an indirect route that provides } \\
\text { secured deal }\end{array}$ \\
\hline Memo 4 & & & $\begin{array}{l}\text { The associated risks couple with market } \\
\text { distance influence or determines choice of } \\
\text { indirect to the market }\end{array}$ \\
\hline Memo 5 & & & $\begin{array}{l}\text { Major player guarantee payment: leads to } \\
\text { readiness to go indirect }\end{array}$ \\
\hline Security of Payment & 19 & & $\begin{array}{l}\text { Client choose indirect route into the market } \\
\text { because of assurance of payment by the big } \\
\text { organization }\end{array}$ \\
\hline Project funding & 20 & & $\begin{array}{l}\text { It is a world Bank funded project and that } \\
\text { makes it more reliable that payment will not } \\
\text { fail at the end of the project }\end{array}$ \\
\hline Project Security & 21 & & $\begin{array}{l}\text { High possibility of Project completion and } \\
\text { good administrative control influenced } \\
\text { participants indirect approach to market } \\
\text { involvement }\end{array}$ \\
\hline Memo 6 & & & $\begin{array}{l}\text { Project dependent Tech transfer calls for } \\
\text { project security to determine direct/indirect } \\
\text { choice }\end{array}$ \\
\hline Memo 7 & & & $\begin{array}{l}\text { Small companies cannot afford big impact of } \\
\text { huge loss, hence indirect approach to transfer }\end{array}$ \\
\hline Memo 8 & & & $\begin{array}{l}\text { Coy capital outlay is an essential factor in } \\
\text { direct or indirect transfer }\end{array}$ \\
\hline
\end{tabular}




\section{Appendix G : Coding for Sample G (Contd.)}

\begin{tabular}{|c|c|c|c|}
\hline Code & Code & $\begin{array}{c}\text { Data } \\
\text { Reference } \\
\end{array}$ & Notes and Quotes from transcribed data \\
\hline Memo 9 & & & $\begin{array}{l}\text { Tech transfer contingent on preliminary } \\
\text { subcontracting will call for extensive security } \\
\text { in terms of payment and project control } \\
\text { which in tum influence entry mode }\end{array}$ \\
\hline Unstable Government & 22 & & $\begin{array}{l}\text { Political instability of the target nation can } \\
\text { have adverse effect on SC's stability in the } \\
\text { event of unfavourable change (affecting e.g } \\
\text { payment) }\end{array}$ \\
\hline Project Financing & 23 & & $\begin{array}{l}\text { Trust factor between western Banks and the } \\
\text { target market Banks, leading to inability to } \\
\text { finance project resulting in indirect approach } \\
\text { to market }\end{array}$ \\
\hline Target Market Risks & 24 & & $\begin{array}{l}\text { Wrong perception of risk level has restrained } \\
\text { most SCs from direct venture }\end{array}$ \\
\hline Memo 10 & & & $\begin{array}{l}\text { Payment pattem of target market (Inflated } \\
\text { payment and corruption does not support } \\
\text { direct entry to market place) }\end{array}$ \\
\hline $\begin{array}{l}\text { Financing Target } \\
\text { Market }\end{array}$ & 25 & & $\begin{array}{l}\text { Effort to finance project in target market } \\
\text { could be frustrating with the financial } \\
\text { institution. This play a substantial role in the } \\
\text { decision for direct/indirect entrance to market }\end{array}$ \\
\hline Memo 11 & & & $\begin{array}{l}\text { Issuance of Letter of Credit is target market } \\
\text { risk perception dependent.. This eventually } \\
\text { affects choice of direct/indirect }\end{array}$ \\
\hline Mgt. Risk Factor & 26 & & $\begin{array}{l}\text { Management risk tolerance determines the } \\
\text { approach to (perceived) risk laden market }\end{array}$ \\
\hline $\begin{array}{l}\text { Organisational Risk } \\
\text { Policy }\end{array}$ & 27 & & $\begin{array}{l}\text { Organisational risk policy determines } \\
\text { approach to market laden with risk }\end{array}$ \\
\hline Memo 12 & & & $\begin{array}{l}\text { Collectively governed outfit takes decision } \\
\text { process allows a broader view of the market } \\
\text { place and thus influence choice of transfer? }\end{array}$ \\
\hline Trade Information & 28 & & $\begin{array}{l}\text { Trade information are determinants and } \\
\text { influential of market decision }\end{array}$ \\
\hline Memo 13 & & & $\begin{array}{l}\text { Gov. base information widely available to } \\
\text { give market situations }\end{array}$ \\
\hline Insurable Market & 29 & & $\begin{array}{l}\text { Volatile market pose challenges to financial } \\
\text { and insurance institution and that present a } \\
\text { wall of resistance to easy access to the } \\
\text { market. Which to a large extent discourages } \\
\text { the small players }\end{array}$ \\
\hline
\end{tabular}




\section{Appendix G : Coding for Sample G (Contd.)}

\begin{tabular}{|c|c|c|c|}
\hline Code & Code & $\begin{array}{c}\text { Data } \\
\text { Reference }\end{array}$ & Notes and Quotes from transcribed data \\
\hline Resource Constraint & 30 & & $\begin{array}{l}\text { There is a minimum expenditure required to } \\
\text { register your presence in the market: The } \\
\text { question is do you have it? }\end{array}$ \\
\hline Associated Cost & 31 & & $\begin{array}{l}\text { Cost developing relationship, visiting the } \\
\text { market etc }\end{array}$ \\
\hline Financial Resources & 32 & & $\begin{array}{l}\text { This major contractor, (taking us into Angola) } \\
\text { must have spent a lot that we cannot afford! }\end{array}$ \\
\hline Confidence Perception & 33 & & $\begin{array}{l}\text { The level of comfort we have with this lead } \\
\text { contractor is satisfactory to our Coy. Hence } \\
\text { the decision to go with them }\end{array}$ \\
\hline Resources & 34 & & $\begin{array}{l}\text { Quite an amount of resources (man hours, } \\
\text { money and materials) has to be expended } \\
\text { before the emergence of contract (if any) }\end{array}$ \\
\hline Market Presence & 35 & & $\begin{array}{l}\text { How long you have been in the industry and } \\
\text { how long you are going to be in the market is } \\
\text { a factor to the target market operator. Ability } \\
\text { to remain influences our choice of } \\
\text { direct/indirect }\end{array}$ \\
\hline Mermo 14 & & & $\begin{array}{l}\text { New comers have the task of validating } \\
\text { themselves to the clients in their new market. } \\
\text { This more than often leads to piggy backing } \\
\text { into new markets }\end{array}$ \\
\hline Market Maintenance & 36 & & $\begin{array}{l}\text { Relationship and product maintenance is key } \\
\text { to our survival and it can be demanding on } \\
\text { resources. We maintain these through travel } \\
\text { cost and engagement of lobbyist }\end{array}$ \\
\hline Resource Constraint & 37 & & \\
\hline Memo 15 & & & $\begin{array}{l}\text { Profitable and well known market may retard } \\
\text { prospect for foreign market! }\end{array}$ \\
\hline Memo 16 & & & $\begin{array}{l}\text { Substantial order require validation of sellers, } \\
\text { otherwise no sale. . }\end{array}$ \\
\hline Memo 17 & & & EDC good at political analysis of market \\
\hline Memo 18 & & & More data than information \\
\hline Indirect Market search & 38 & & $\begin{array}{l}\text { We use local agents to search the market to } \\
\text { collect data as needed }\end{array}$ \\
\hline Memo 19 & & & $\begin{array}{l}\text { Market must be maintained /serviced to } \\
\text { maintain position }\end{array}$ \\
\hline Memo 20 & & & $\begin{array}{l}\text { Cuba's closed led to shifted attention? } \\
\text { Pressure of sales lead to acceptance } \\
\text { perceived high risky area? }\end{array}$ \\
\hline
\end{tabular}




\section{Appendix G : Coding for Sample G (Contd.)}

\begin{tabular}{|c|c|c|c|}
\hline Code & Code & $\begin{array}{c}\text { Data } \\
\text { Reference }\end{array}$ & Notes and Quotes from transcribed data \\
\hline Reso Constr Mrkt Maint & 39 & & $\begin{array}{l}\text { Getting the next order require much more } \\
\text { spending which we cannot afford }\end{array}$ \\
\hline Keystone Potential & 40 & & $\begin{array}{l}\text { We need reps that can assist to follow } \\
\text { through with existing markets and new ones }\end{array}$ \\
\hline Market Agents & 41 & & Target market researchers and facilitators \\
\hline Memo 21 & & & $\begin{array}{l}\text { Not quite easy maintaining a more like stable } \\
\text { foreign rep. with limited resources. MNEs can } \\
\text { afford subsidiary, but even agent } \\
\text { maintenance is challenging! }\end{array}$ \\
\hline Resource Constraint & 42 & & $\begin{array}{l}\text { Not quite easy maintaining the field agents } \\
\text { and associated cost }\end{array}$ \\
\hline $\begin{array}{l}\text { Resour Constr Mrkt } \\
\text { Expansion }\end{array}$ & 43 & & $\begin{array}{l}\text { Inability to cope with the volume of material } \\
\text { submission required (Bids) to prospect into } \\
\text { new market is also limited by our resources. } \\
\text { Most of them will need almost a man-day to } \\
\text { submit. }\end{array}$ \\
\hline Resource Constraint & 44 & & $\begin{array}{l}\text { At those points we ask ourselves: Can we } \\
\text { really afford this as a small organisation? }\end{array}$ \\
\hline Memo 22 & & & $\begin{array}{l}\text { Turn jobs down for lack of resources but } t \\
\text { willing to do the job if a MNE can roll in their } \\
\text { resources }\end{array}$ \\
\hline Memo 23 & & & $\begin{array}{l}\text { Resource constraint and customer related risk } \\
\text { play key roles in choice of direct or indirect }\end{array}$ \\
\hline Customer Risk & 45 & & $\begin{array}{l}\text { Does the customer have the capacity to issue } \\
\text { the project as promised? }\end{array}$ \\
\hline Technology Absorption & 46 & & $\begin{array}{l}\text { Is the customer able to directly absorb our } \\
\text { technology? What level of technology is } \\
\text { acceptable to the market, and do we have it? } \\
\text { Or are we better of going to the market with a } \\
\text { bigger organisation that has training facility in } \\
\text { place. }\end{array}$ \\
\hline Simple Tech & 47 & & $\begin{array}{l}\text { The locals could fix the problems because } \\
\text { Tech was quite simple }\end{array}$ \\
\hline Technology Absorption & 48 & & $\begin{array}{l}\text { The level of tech professionals were quite } \\
\text { high }\end{array}$ \\
\hline Technology Capability & 49 & & $\begin{array}{l}\text { When the market has high local capability, we } \\
\text { SCs can readily identify with their market. }\end{array}$ \\
\hline Memo 24 & & & $\begin{array}{l}\text { Clients' absorptive capacity is in direct } \\
\text { correlation with choice of direct or indirect } \\
\text { transfer. It influences the necessary ground } \\
\text { support required in this industry technology } \\
\text { requirement. }\end{array}$ \\
\hline
\end{tabular}




\section{Appendix G : Coding for Sample G (Contd.)}

\begin{tabular}{|c|c|c|c|}
\hline Code & Code & $\begin{array}{c}\text { Data } \\
\text { Reference }\end{array}$ & Notes and Quotes from transcribed data \\
\hline No Capacity & 50 & & $\begin{array}{l}\text { In our current market (approached indirectly), } \\
\text { the people has no capacity to absorb } \\
\text { anything. The war has tom the whole place } \\
\text { apart. No education or learning opportunity }\end{array}$ \\
\hline Memo 25 & & & $\begin{array}{l}\text { Lack of after sales support partially } \\
\text { influenced the choice of indirect to Angola: } \\
\text { Where there is no formal education, direct } \\
\text { Tech transfer can be very challenging in the } \\
\text { face of SC's scarce resources. }\end{array}$ \\
\hline Resource Base & 51 & & $\begin{array}{l}\text { Since there may not be education in that } \\
\text { region for a while and we cannot afford to } \\
\text { provide the training, we have gone the route } \\
\text { of indirect }\end{array}$ \\
\hline Mrkt_Proj Continuity & 52 & & $\begin{array}{l}\text { Our current market will still take quite some } \\
\text { time to complete. It is an extensive work }\end{array}$ \\
\hline Market Stability & 53 & & What can go wrong in the target market? \\
\hline Cost Risk & 54 & & $\begin{array}{l}\text { If anything thus go wrong, what is the cost to } \\
\text { us and its associated risks }\end{array}$ \\
\hline New Market Player & 55 & & $\begin{array}{l}\text { More so, we are not known in the market } \\
\text { place }\end{array}$ \\
\hline Memo 26 & & & $\begin{array}{l}\text { General conceptions that bigger org. have } \\
\text { capacity to take risk }\end{array}$ \\
\hline Keystone Organization & 56 & & $\begin{array}{l}\text { We need someone who is a go-between that } \\
\text { have technical knowledge }\end{array}$ \\
\hline Market Knowledge & 57 & & $\begin{array}{l}\text { We need someone who is a go-between that } \\
\text { have technical knowledge }\end{array}$ \\
\hline Keystone organization & 58 & & $\begin{array}{l}\text { Market knowledge is obviously of great } \\
\text { concern to SCs }\end{array}$ \\
\hline Memo 27 & & & $\begin{array}{l}\text { We need someone who is a go-between that } \\
\text { have technical knowledge }\end{array}$ \\
\hline Memo 28 & & & $\begin{array}{l}\text { Perception of big players as being } \\
\text { resourceful }\end{array}$ \\
\hline Ground Support & 59 & & $\begin{array}{l}\text { Bigger company can afford local ground } \\
\text { support }\end{array}$ \\
\hline $\begin{array}{l}\text { Product } \\
\text { rejection/handling }\end{array}$ & 60 & & $\begin{array}{l}\text { Going indirectly with a bigger outfit provides } \\
\text { respite when issues do arise in the target } \\
\text { market }\end{array}$ \\
\hline Ground Support & 61 & & $\begin{array}{l}\text { Direct access to market is easier Where } \\
\text { Target market professionals are able to } \\
\text { provide ground support }\end{array}$ \\
\hline Level of Education & 62 & & $\begin{array}{l}\text { Level of education in the target market is of } \\
\text { high consideration for direct market access }\end{array}$ \\
\hline
\end{tabular}




\section{Appendix G : Coding for Sample G (Contd.)}

\begin{tabular}{|c|c|c|c|}
\hline Code & Code & $\begin{array}{c}\text { Data } \\
\text { Reference }\end{array}$ & Notes and Quotes from transcribed data \\
\hline Finance Constraint & 63 & & $\begin{array}{l}\text { The government appears to have place a } \\
\text { ceiling on what they are willing to finance and } \\
\text { guarantee }\end{array}$ \\
\hline $\begin{array}{l}\text { Tech Origin Finance } \\
\text { Situation }\end{array}$ & 64 & & $\begin{array}{l}\text { Availability of funding to Technology coy here in } \\
\text { Canada enhances direct market access }\end{array}$ \\
\hline $\begin{array}{l}\text { Risk Averse Home } \\
\text { Govt }\end{array}$ & 65 & & $\begin{array}{l}\text { The government is pro mining and other } \\
\text { industry. Hence they are willing to fund projects } \\
\text { in that industry than in our sector }\end{array}$ \\
\hline Home Govt Support & 66 & & $\begin{array}{l}\text { The cost of financial guarantee is quite high } \\
\text { and the eartier the government commit itself } \\
\text { into supporting SCs the easier it become for } \\
\text { SCs to penetrate foreign market }\end{array}$ \\
\hline Market Agents & 67 & & A local agent invited us into the market \\
\hline Prod Acceptability & 68 & & $\begin{array}{l}\text { The product was accepted afar an initial testing } \\
\text { period and that opened the way }\end{array}$ \\
\hline Payment instrument & 69 & & $\begin{array}{l}\text { Securing letter of credit was a serious issue } \\
\text { and that delayed us for quite a while } \\
\end{array}$ \\
\hline Finance Constraint & 70 & & $\begin{array}{l}\text { Cost of funding was quite restrictive. High } \\
\text { interest rate and Bank charges all due to risk } \\
\text { perception of the market }\end{array}$ \\
\hline Functional Agent & 71 & & $\begin{array}{l}\text { Ground agent was useful during renegotiation } \\
\text { exercise }\end{array}$ \\
\hline Market Continuity & 72 & & $\begin{array}{l}\text { The second order is a pointer that recovery of } \\
\text { cost is possible. Such assurance promotes } \\
\text { direct approach }\end{array}$ \\
\hline Government Stability & 73 & & $\begin{array}{l}\text { Government stability still constitute a } \\
\text { substantial percent of factors that determines } \\
\text { approach to the market place }\end{array}$ \\
\hline Finance Constraints & 74 & & $\begin{array}{l}\text { Instability in government leads to high level of } \\
\text { risk perception and consequently restrain in the } \\
\text { release of funds }\end{array}$ \\
\hline
\end{tabular}




\section{Appendix H : Coding for Sample H}

\begin{tabular}{|c|c|c|c|}
\hline Code & Code & $\begin{array}{c}\text { Data } \\
\text { Reference }\end{array}$ & Notes and Quotes from transcribed data \\
\hline Specialization & 1 & & $\begin{array}{l}\text { Specialized trade defines the market scope } \\
\text { and the search criteria }\end{array}$ \\
\hline Quality Control & 2 & & $\begin{array}{l}\text { Product line may be of secondary } \\
\text { consideration to potential buyer }\end{array}$ \\
\hline Existing Market & 3 & & $\begin{array}{l}\text { Paper and pulp is an old market that has } \\
\text { defined industry players and defined market }\end{array}$ \\
\hline Old Market & 4 & & $\begin{array}{l}\text { Pulp business is old and the market } \\
\text { locations are defined (even by nature) }\end{array}$ \\
\hline Tech Source & 5 & & $\begin{array}{l}\text { Canada has just come up with pulp industry } \\
\text { related technology. Was of foreign origin }\end{array}$ \\
\hline Competence & 6 & & $\begin{array}{l}\text { Technology requires skills to implement the } \\
\text { advances in computer application to the } \\
\text { existing technology }\end{array}$ \\
\hline Local Market & 7 & & A versatile player in the local market \\
\hline Developed Market & 8 & & Supplier to developed economy \\
\hline Developing Market & 9 & & Supplier to developing economy \\
\hline Collapsed Market & 10 & & $\begin{array}{l}\text { Backed off some market for lack of the } \\
\text { target mark support }\end{array}$ \\
\hline Remote Market & 11 & & One-off market opportunity \\
\hline Assembling & 12 & & Build up machineries \\
\hline Upgrading/Refurbishing & 13 & & $\begin{array}{l}\text { Improving old and obsolete technology with } \\
\text { new and modern technology }\end{array}$ \\
\hline Developing Market & 14 & & Mexico, Brazil and Chile \\
\hline Mix Process & 15 & & $\begin{array}{l}\text { Exchange of personnel to finalize transfer } \\
\text { (Staff personnel to install and Trained client } \\
\text { staff to maintain) }\end{array}$ \\
\hline Memo 1 & & & $\begin{array}{l}\text { When technology is advance/high profile, it } \\
\text { calls for mix process in export? }\end{array}$ \\
\hline Product Plus & 16 & & $\begin{array}{l}\text { Tech source in-house training condition for } \\
\text { accepting tech }\end{array}$ \\
\hline Local Link & 17 & & $\begin{array}{l}\text { Local representatives are always engaged } \\
\text { to penetrate the local market }\end{array}$ \\
\hline Memo 2 & & & $\begin{array}{l}\text { Loose link to keep the day to day } \\
\text { communication on going? This is market link } \\
\text { (not the tech transfer). Market link appear to } \\
\text { be always indirect not necessarily the tech } \\
\text { transfer. }\end{array}$ \\
\hline
\end{tabular}




\section{Appendix H : Coding for Sample H (Contd.)}

\begin{tabular}{|c|c|c|c|}
\hline Code & Code & $\begin{array}{c}\text { Data } \\
\text { Reference }\end{array}$ & Notes and Quotes from transcribed data \\
\hline Memo 3 & & & $\begin{array}{l}\text { If there is continuity, will they adopt another strategy? } \\
\text { Maybe use a permanent local rep or establish a local } \\
\text { office? }\end{array}$ \\
\hline Memo 4 & & & There is always a need for a local link to the market! \\
\hline $\begin{array}{l}\text { Market } \\
\text { Size }\end{array}$ & 18 & & The Pulp/Paper industry claimed to be narrow \\
\hline Memo 5 & & & $\begin{array}{l}\text { Market search may not be too demanding. It may be } \\
\text { a question of edging into the existing market for this } \\
\text { industry. How does this affect direct or indirect? } \\
\text { Does it not in fact specify the mode ahead of time? }\end{array}$ \\
\hline Memo 6 & & & $\begin{array}{l}\text { This Paragraph: potential users are small: Where } \\
\text { users are small, market information are readily } \\
\text { obtained. Link agent are still indispensable }\end{array}$ \\
\hline Memo 7 & & & $\begin{array}{l}\text { Lack of market information still exists in spite of the } \\
\text { narrow nature of the industry! }\end{array}$ \\
\hline Memo 8 & & & $\begin{array}{l}\text { Lack of market knowledge prevents commitment of } \\
\text { resources. Scared of the unknown! }\end{array}$ \\
\hline $\begin{array}{l}\text { Market } \\
\text { Size }\end{array}$ & 19 & & $\begin{array}{l}\text { Market dimension in terms of capacity or part of a } \\
\text { multinationals or family owned mills }\end{array}$ \\
\hline Memo 9 & & & MARKET DIMENSIONS? \\
\hline Memo 10 & & & $\begin{array}{l}\text { Not a branded product! what is the effect in approaching } \\
\text { the new market? }\end{array}$ \\
\hline Memo 11 & & & $\begin{array}{l}\text { Specific customer cost wise. TTC may appear too } \\
\text { cheap for some patronage Will they need } \\
\text { aggressive sales strategy, does this imply indirect } \\
\text { transfer, does this explain why they look for } \\
\text { multinationals? }\end{array}$ \\
\hline Mix Mode & 20 & & $\begin{array}{l}\text { We go direct and through multinationals at other } \\
\text { times depending.... }\end{array}$ \\
\hline Memo 12 & & & $\begin{array}{l}\text { Choice of direct/indirect is a function of the end user } \\
\text { and/or the project. }\end{array}$ \\
\hline $\begin{array}{l}\text { Unique } \\
\text { Tech }\end{array}$ & 21 & & $\begin{array}{l}\text { We go indirect (through MTNe) when the } \\
\text { multinational do not have our type of service in their } \\
\text { product line }\end{array}$ \\
\hline Memo 13 & & & $\begin{array}{l}\text { Direct or indirect is a function of the capacity of the } \\
\text { Multinationals }\end{array}$ \\
\hline Memo 14 & & & $\begin{array}{l}\text { Confirmation of RCM3 above? They have a standing } \\
\text { arrangement with the multinationals that do not carry } \\
\text { their type of service!! }\end{array}$ \\
\hline
\end{tabular}




\section{Appendix H : Coding for Sample H (Contd.)}

\begin{tabular}{|c|c|c|c|}
\hline Code & Code & $\begin{array}{c}\text { Data } \\
\text { Reference }\end{array}$ & Notes and Quotes from transcribed data \\
\hline Mix Mode & 22 & & $\begin{array}{l}\text { This a conditional direct or indirect: MTN have no } \\
\text { parallel service; we supply through them or direct to } \\
\text { client at their influence/influence }\end{array}$ \\
\hline $\begin{array}{l}\text { Non unique } \\
\text { Tech }\end{array}$ & 23 & & $\begin{array}{l}\text { MTNe carries competitive product line with ours: we } \\
\text { go direct but face competition! }\end{array}$ \\
\hline Memo 15 & & & $\begin{array}{l}\text { Direct/direct becomes a function of unique } \\
\text { technology not carried by MNE }\end{array}$ \\
\hline Memo 16 & & & $\begin{array}{l}\text { Where brand name is not known, intermediary service } \\
\text { provider will be readily embraced? }\end{array}$ \\
\hline $\begin{array}{l}\text { Market } \\
\text { Research }\end{array}$ & 24 & & $\begin{array}{l}\text { An excellent market research identifying sales leads, } \\
\text { great opportunities can influence indirect mode } \\
\text { through the provider of information }\end{array}$ \\
\hline Memo 17 & & & $\begin{array}{l}\text { Defines possible functions of a Keystone organisation in } \\
\text { the Tech transfer environment }\end{array}$ \\
\hline Memo 18 & & & $\begin{array}{l}\text { Intermediary must have market and industry } \\
\text { knowledge! }\end{array}$ \\
\hline Memo 19 & & & Willing to pay for senvices that produces export potential! \\
\hline $\begin{array}{l}\text { Payable } \\
\text { Service }\end{array}$ & 25 & & $\begin{array}{l}\text { Willing to pay for intermediary services that provide } \\
\text { functional link to market }\end{array}$ \\
\hline Memo 20 & & & $\begin{array}{l}\text { Current govt services inadequate? Need for } \\
\text { improved and robust service provider! }\end{array}$ \\
\hline $\begin{array}{l}\text { Limited } \\
\text { Services }\end{array}$ & 26 & & Government supplies data but less information \\
\hline $\begin{array}{l}\text { Customized } \\
\text { infor }\end{array}$ & 27 & & $\begin{array}{l}\text { Country specific information from an intermediary will be } \\
\text { highly favourable for business }\end{array}$ \\
\hline $\begin{array}{l}\text { Robust } \\
\text { Services }\end{array}$ & 28 & & Specific connection to potential organization \\
\hline $\begin{array}{l}\text { Robust } \\
\text { Services }\end{array}$ & 29 & & $\begin{array}{l}\text { Agents with direct customer sites and can push product } \\
\text { towards sales }\end{array}$ \\
\hline Memo 21 & & & Agency that provides much more! \\
\hline Memo 22 & & & A type of Keystone senvice provider! (Canadian C.C) \\
\hline Memo 23 & & & $\begin{array}{l}\text { Was this intention realised or they have many } \\
\text { hurdles? Are other respondents aware of their } \\
\text { existence? (CCC could not generate the mass } \\
\text { required to support the services??) }\end{array}$ \\
\hline Memo 24 & & & $\begin{array}{l}\text { Potential keystone must be able to put a big bait } \\
\text { together for all to partake. They intend to put a big } \\
\text { bait together for the smaller Canadian companies to } \\
\text { come together }\end{array}$ \\
\hline Payable Service & 30 & & Individual firm to jointly pay for the services \\
\hline
\end{tabular}




\section{Appendix H : Coding for Sample H (Contd.)}

\begin{tabular}{|c|c|c|c|}
\hline Code & Code & $\begin{array}{c}\text { Data } \\
\text { Reference }\end{array}$ & Notes and Quotes from transcribed data \\
\hline Memo 25 & & & Keystone will be a welcome idea? (if the service is right! \\
\hline Memo 26 & 31 & & $\begin{array}{l}\text { Canada is full of small size organizations "bunch } \\
\text { of small companies. You have very narrow market } \\
\text { disciplines and they normally don't have the } \\
\text { resources to go after the world" }\end{array}$ \\
\hline Memo 27 & & & $\begin{array}{l}\text { Canadian small scales are in fact Micro? and will } \\
\text { surely need help? Better assistance than currently } \\
\text { available! }\end{array}$ \\
\hline Memo 28 & & & $\begin{array}{l}\text { Keystone with an enabling role will most likely be } \\
\text { relevant to the small companies "good cause you pull } \\
\text { the resources from a bunch of people that have specific } \\
\text { technologies and skill and then together is a very } \\
\text { powerful tool" }\end{array}$ \\
\hline Memo 29 & & & $\begin{array}{l}\text { Potential for keystone organization that pull all } \\
\text { together! "everybody seem interested but there is } \\
\text { no body to bring them together" }\end{array}$ \\
\hline Memo 30 & & & $\begin{array}{l}\text { Need extemal party to implement such Keystone! } \\
\text { "it's difficult, so somebody has to play that role and } \\
\text { its difficult for anyone to play that role because } \\
\text { that's not the business we are in, we are in } \\
\text { business of selling our technology not putting } \\
\text { consultants together" }\end{array}$ \\
\hline Business Hub & & & It will be welcome idea! \\
\hline Memo 31 & 32 & & $\begin{array}{l}\text { A type of keystone functions and services that } \\
\text { must be in place to attract patronage }\end{array}$ \\
\hline Limited Services & & & Expected function of a keystone! \\
\hline Tech Type & 33 & & $\begin{array}{l}\text { Trade commissioners and agent have limited } \\
\text { assistance they can provide }\end{array}$ \\
\hline Memo 32 & 34 & & $\begin{array}{l}\text { Not a standalone type of technology. It thus } \\
\text { require an umbrella organization to transfer } \\
\text { technology }\end{array}$ \\
\hline Org. Continuity & & & $\begin{array}{l}\text { Indirect transfer influenced by the nature of the } \\
\text { service provided (and the industry). }\end{array}$ \\
\hline Org. Continuity & 35 & & $\begin{array}{l}\text { End use expects the presence of the supplier to } \\
\text { ensure continuity of service for which this industry } \\
\text { may not be able to sustained going alone. Hence } \\
\text { the leveraging on large organizations }\end{array}$ \\
\hline Leveraging-MTNe & 36 & & "How long are you going to be around" \\
\hline
\end{tabular}




\section{Appendix H : Coding for Sample H (Contd.)}

\begin{tabular}{|c|c|c|c|}
\hline Code & Code & $\begin{array}{c}\text { Data } \\
\text { Reference }\end{array}$ & Notes and Quotes from transcribed data \\
\hline Unique Tech & 37 & & $\begin{array}{l}\text { "so if you are under the umbrella of larger } \\
\text { organization that can give a comfort zone to..." }\end{array}$ \\
\hline Memo 33 & 38 & & $\begin{array}{l}\text { We always have to go through somebody } \\
\text { else...... }\end{array}$ \\
\hline Representatives & & & Another reason for indirect exportation \\
\hline $\begin{array}{l}\text { Obvious } \\
\text { Presence }\end{array}$ & 39 & & $\begin{array}{l}\text { Users require local presence (Note this is } \\
\text { particularly for marketing, not quite for tech } \\
\text { transfer?? }\end{array}$ \\
\hline Memo 34 & 40 & & $\begin{array}{l}\text { Need a local number to call when there is } \\
\text { problem }\end{array}$ \\
\hline Memo 35 & & & $\begin{array}{l}\text { More of indirect than direct (in pulp and paper } \\
\text { service tech?) }\end{array}$ \\
\hline $\begin{array}{l}\text { Reference } \\
\text { Services } \\
\end{array}$ & & & $\begin{array}{l}\text { Depend on government services on foreign } \\
\text { market information for strategic planning and } \\
\text { decision }\end{array}$ \\
\hline Memo 36 & 41 & & $\begin{array}{l}\text { Trade commissioner good for reference services } \\
\text { towards funding. }\end{array}$ \\
\hline Tech. Gap & & & $\begin{array}{l}\text { Govt. sponsored research agency relevant to } \\
\text { development of SSES effort to export! } \\
\end{array}$ \\
\hline Memo 37 & 42 & & $\begin{array}{l}\text { Tech gap between end user and supplier hinder } \\
\text { transfer (.... To India) }\end{array}$ \\
\hline \begin{tabular}{|l|} 
Tech. \\
Absorption \\
\end{tabular} & & & $\begin{array}{l}\begin{array}{l}\text { Local absorptive capacity determines direct or } \\
\text { indirect }\end{array} \\
\end{array}$ \\
\hline Memo 38 & 43 & & $\begin{array}{l}\text { Readiness of end users to accept technology } \\
\text { (found to hinder transfer) ...go indirect to } \\
\text { facilitate learning through locally available } \\
\text { organization??? }\end{array}$ \\
\hline Tech Gap & & & $\begin{array}{l}\text { Comfortable with obsolete stuffs? Maybe learning is } \\
\text { slow and they are far behind }\end{array}$ \\
\hline Obsolete Tech & 44 & & $\begin{array}{l}\text { Large difference in tech knowledge preventing } \\
\text { direct transfer }\end{array}$ \\
\hline Memo 39 & 45 & & $\begin{array}{l}\text { Dumping of old technology prevents steady } \\
\text { transfer to developed nation (because of industry } \\
\text { type??) }\end{array}$ \\
\hline Memo 40 & & & $\begin{array}{l}\text { Technology is rendered obsolete too soon and } \\
\text { rate of recycling too high. Not environmentally } \\
\text { friendly. This is an industry specific issue though. }\end{array}$ \\
\hline Memo 41 & & & RCM39 confirmed: industry specific experience! \\
\hline
\end{tabular}




\section{Appendix I : Market Knowledge}

\begin{tabular}{|c|c|c|}
\hline Code & Code & Quotes and Notes from transcribed data \\
\hline Market. Information & A3 & $\begin{array}{l}\text { we've done some research into the Caribbean, Latin America, } \\
\text { and parts of Asia. }\end{array}$ \\
\hline Agents & A4 & Knowing who to contact \\
\hline Local Agents & A5 & getting the contacts in those areas \\
\hline Incumbents & A6 & people that have been dealing in those markets \\
\hline Agents/intermediaries & A7 & people who knows the market \\
\hline Market. Information & A8 & $\begin{array}{l}\text {... at this moment in time, and to determine whether there are } \\
\text { opportunities there }\end{array}$ \\
\hline Market. Information & A9 & the problem is actually trying to get that information \\
\hline Informed Agents & A10 & $\begin{array}{l}\text { I think the challenge is actually to locate who that.. who really } \\
\text { has got the information }\end{array}$ \\
\hline Market Knowledge & A11 & Who do you speak to? How do you know who to speak to? \\
\hline Market information & A12 & $\begin{array}{l}\text { somebody that will give you a focused information that is } \\
\text { relevant to your industry }\end{array}$ \\
\hline Market Knowledge & A17 & Cause you don't know who your customer is \\
\hline Market information & A24 & $\begin{array}{l}\text { good information.. focused information that leads you to your } \\
\text { right market }\end{array}$ \\
\hline Market information & A28 & I said the real problem is actually finding them \\
\hline Market Knowledge & A29 & $\begin{array}{l}\text { they are using the solids for fertilizers for farming and } \\
\text { agriculture }\end{array}$ \\
\hline Market information & A31 & Caribbean where the fertility of the soil is actually very low \\
\hline Market link & B4 & $\begin{array}{l}\text {.. So sometimes its personal contacts, networking, customers, } \\
\text { we deal with distributors, you know sales people }\end{array}$ \\
\hline Local representatives & B5 & we have even had many actual representatives. .... \\
\hline Local presence & B6 & $\begin{array}{l}\text {....for developing countries, the approach we are going to take } \\
\text { in the places like india, for example, is to hire a local firm, to act } \\
\text { as sort of sales and technical representative. }\end{array}$ \\
\hline Local representative & B7 & $\begin{array}{l}\text { we believe that to do a good job, you need more than just a } \\
\text { sales person, }\end{array}$ \\
\hline Market. Presence & B8 & $\begin{array}{l}\text {... you often need a technical person in the country who } \\
\text { understands the country }\end{array}$ \\
\hline Market Rep & B25 & $\begin{array}{l}\text { that's where hiring the right team in the country is going to help } \\
\text { us because they know, they know the pain point }\end{array}$ \\
\hline Client's need & B26 & $\begin{array}{l}\text { they know the pain that is been suffered by for example the } \\
\text { telecommunications company in that country }\end{array}$ \\
\hline Agent/Intermediary & B27 & $\begin{array}{l}\text { they can sell our product in those areas very well because they } \\
\text { can say I know this is your pain }\end{array}$ \\
\hline Local Reps & B28 & $\begin{array}{l}\text { And they can put it into words that are understood by the people } \\
\text { of the country because they themselves are from the country. }\end{array}$ \\
\hline
\end{tabular}




\section{Appendix I : Market Knowledge (Contd.)}

\begin{tabular}{|c|c|c|}
\hline Code & Code & Quotes and Notes from transcribed data \\
\hline Market information & B35 & $\begin{array}{l}\text { Right now, 1.2billion litres of diesel is burnt every year powering } \\
\text { generators that run the cell phone towers in India. So the } \\
\text { government is passing legislation to make that illegal. So, the } \\
\text { telecoms operators must get their towers to run of either grid } \\
\text { energy or solar energy or wind energy }\end{array}$ \\
\hline Open Infor. Session & $\mathrm{C4}$ & $\begin{array}{l}\text { Relatively new tech, market information disseminated and } \\
\text { collected through conferences and info session }\end{array}$ \\
\hline Personal Networking & C5 & $\begin{array}{l}80 \% \text { market information through personal contacts (the tech } \\
\text { addresses a small market niche }\end{array}$ \\
\hline Market Knowledge & C6 & Posses market knowledge of the South Americas and Brazil \\
\hline Cost of Alternative & D8 & Existing cost of energy in the target market \\
\hline Market information & D18 & $\begin{array}{l}\text { information of existing market are scarce. We need more } \\
\text { market information }\end{array}$ \\
\hline Prod. Existing cost & F6 & $\begin{array}{l}\text { Local cost of power determines the viability of our product in } \\
\text { the target market. }\end{array}$ \\
\hline Location & F7 & Global regional price of energy influence our choice of market \\
\hline$R \& D$ & F12 & $\begin{array}{l}\text { We have research team in place that investigate the market to } \\
\text { determine the direction to go }\end{array}$ \\
\hline Local Agents & F14 & We do hire some local agent to assist in the target market \\
\hline Consultant Agents & F15 & $\begin{array}{l}\text { we work with local consultants to develop the various } \\
\text { opportunities }\end{array}$ \\
\hline Location Information & F16 & $\begin{array}{l}\text { We need this consultant to assist to determine the Cities and } \\
\text { towns that are ready for the Technology }\end{array}$ \\
\hline Developing Market & G5 & $\begin{array}{l}\text { Product appeals to developing market due to lack of standards } \\
\text { in such market }\end{array}$ \\
\hline Market indicators/index & G15 & $\begin{array}{l}\text { To launch into the market, directly or indirectly: economic } \\
\text { factors, sociological and technological factors in the market } \\
\text { place are relevant in the decision process }\end{array}$ \\
\hline Risk & G16 & $\begin{array}{l}\text { Risk and level of exposure in terms of vulnerability, security and } \\
\text { safety }\end{array}$ \\
\hline Trade Information & G28 & $\begin{array}{l}\text { Trade information are determinants and influential of market } \\
\text { decision }\end{array}$ \\
\hline Indirect Market search & G38 & $\begin{array}{l}\text { We use local agents to search the market to collect data as } \\
\text { needed }\end{array}$ \\
\hline Market Agents & G41 & Target market researchers and facilitators \\
\hline Market Knowledge & G57 & $\begin{array}{l}\text { We need someone who is a go-between that have technical } \\
\text { knowledge }\end{array}$ \\
\hline G memo 27 & & $\begin{array}{l}\text { We need someone who is a go-between that have technical } \\
\text { knowledge }\end{array}$ \\
\hline
\end{tabular}




\section{Appendix I : Market Knowledge (Contd.)}

\begin{tabular}{|c|c|c|}
\hline Code & Code & Quotes and Notes from transcribed data \\
\hline Existing Market & H3 & $\begin{array}{l}\text { Paper and pulp is an old market that has defined industry players } \\
\text { and defined market }\end{array}$ \\
\hline Old Market & $\mathrm{H4}$ & $\begin{array}{l}\text { Pulp business is old and the market locations are defined (even by } \\
\text { nature) }\end{array}$ \\
\hline Local Link & $\mathrm{H} 17$ & $\begin{array}{l}\text { Local representatives are always engaged to penetrate the local } \\
\text { market }\end{array}$ \\
\hline Market Size & H19 & $\begin{array}{l}\text { Market dimension in terms of capacity or part of a multinationals or } \\
\text { family owned mills }\end{array}$ \\
\hline Mix Mode & $\mathrm{H} 20$ & We go direct and through multinationals at other times depending. . \\
\hline Org. Continuity & H35 & $\begin{array}{l}\text { End use expects the presence of the supplier to ensure continuity } \\
\text { of service for which this industry may not be able to sustained going } \\
\text { alone. Hence the leveraging on large organizations }\end{array}$ \\
\hline Org. Continuity & H36 & "How long are you going to be around" \\
\hline Representatives & $\mathrm{H} 39$ & $\begin{array}{l}\text { Users require local presence (Note this is particularly for marketing, } \\
\text { not quite for tech transfer?? }\end{array}$ \\
\hline Obvious Presence & $\mathrm{H} 40$ & Need a local number to call when there is problem \\
\hline
\end{tabular}




\section{Appendix J : Limited Resources}

\begin{tabular}{|c|c|c|}
\hline Code & Code & Notes and Quotes from transcribed data \\
\hline Resource constraint & A21 & $\begin{array}{l}\text { Receivable is not a problem, it's a question of actually receiving the } \\
\text { receivable }\end{array}$ \\
\hline Resource & A33 & the biggest cost is going to be man power \\
\hline Finance & B10 & $\begin{array}{l}\text { our biggest challenges in those markets is actually our own } \\
\text { financing }\end{array}$ \\
\hline Financial Constraint & B12 & $\begin{array}{l}\text { You have to be willing to invest in the country essentially, and we } \\
\text { haven't had the finances to do that. }\end{array}$ \\
\hline Funding & B13 & $\begin{array}{l}\text { So we are just completing a new financing now, and a, quite a lot } \\
\text { of that, money we are raising is actually going before getting into } \\
\text { some of these countries }\end{array}$ \\
\hline Access to funding & B14 & Usually negative... and especially for the African markets, \\
\hline B memo 2 & & $\begin{array}{l}\text { Investors are not favourably disposed to funding the developing } \\
\text { nation as a result of their high risk perception of the market. }\end{array}$ \\
\hline Funding & B16 & $\begin{array}{l}\text { but a lot of our investors don't believe it. So it's been difficult to } \\
\text { raise money. }\end{array}$ \\
\hline Govt. Funding & B38 & $\begin{array}{l}\text { The Canadian government would loan the company in Chile the } \\
\text { money which then that company would in turn, then buy the } \\
\text { batteries from us. }\end{array}$ \\
\hline Payment & B39 & $\begin{array}{l}\text { They are companies that already have good strong revenue } \\
\text { track records. }\end{array}$ \\
\hline $\begin{array}{l}\text { Availability of } \\
\text { Resources }\end{array}$ & B46 & $\begin{array}{l}\text { h..... .called CCC eeee which helps with the military side of } \\
\text { of the same if I want to sell to a military organization, they do a lot } \\
\text { things like that. }\end{array}$ \\
\hline Resource Constraint & C18 & $\begin{array}{l}\text { no in house staff nor resources to keep the level of staff required } \\
\text { to relate with EDC }\end{array}$ \\
\hline Resource Con & D13 & $\begin{array}{l}\begin{array}{l}\text { Financial constraints to finance the marketing of the target } \\
\text { market }\end{array} \\
\end{array}$ \\
\hline Limited Capacity & D14 & $\begin{array}{l}\text { We can provide sufficient man-hour but we need fund to move to } \\
\text { the next level }\end{array}$ \\
\hline Resource Constraint & D16 & $\begin{array}{l}\text { We need to have people on ground in the target market, but we } \\
\text { cannot afford that }\end{array}$ \\
\hline Capital constraint & D22 & We cannot provide the necessary funding for all we have to do \\
\hline Keystone Org: & D23 & $\begin{array}{l}\text { bring together the various team leaders in the higher levels, the } \\
\text { government, the EDC level etc. That's missing ingredient }\end{array}$ \\
\hline Financial Resources & D24 & $\begin{array}{l}\text { Grants or any financial aid will be required to move on to this } \\
\text { market }\end{array}$ \\
\hline Resources & F17 & Private investors \\
\hline Leveraged Resources & F18 & $\begin{array}{l}\text { Internally sourced investors are used to finance project and } \\
\text { Angel investors too }\end{array}$ \\
\hline
\end{tabular}




\section{Appendix J : Limited Resources (Contd.)}

\begin{tabular}{|c|c|c|}
\hline Code & Code & Notes and Quotes from transcribed data \\
\hline Age & F26 & $\begin{array}{l}\text { Old SSEs sometimes develop the capacity of big organization } \\
\text { over a long period of time }\end{array}$ \\
\hline Payment & G13 & $\begin{array}{l}\text { SSE was willing to go to any market through any route that } \\
\text { guarantees payment }\end{array}$ \\
\hline Resource Constraint & G14 & $\begin{array}{l}\text { Payment is critical to us. Exporting abroad can drain our } \\
\text { resources, hence the reason for security of payment }\end{array}$ \\
\hline Security of Payment & G19 & $\begin{array}{l}\text { Client choose indirect route into the market because of } \\
\text { assurance of payment by the big organization }\end{array}$ \\
\hline Project funding & G20 & $\begin{array}{l}\text { It is a world Bank funded project and that makes it more } \\
\text { reliable that payment will not fail at the end of the project }\end{array}$ \\
\hline Project Security & G21 & $\begin{array}{l}\text { High possibility of Project completion and good administrative } \\
\text { control influenced participants indirect approach to market } \\
\text { involvement }\end{array}$ \\
\hline Market Presence & G35 & $\begin{array}{l}\text { How long you have been in the industry and how long you are } \\
\text { going to be in the market is a factor to the target market } \\
\text { operator. Ability to remain influences our choice of } \\
\text { direct/indirect }\end{array}$ \\
\hline Reso Constr Mrkt Maint & G39 & $\begin{array}{l}\text { Getting the next order require much more spending which we } \\
\text { cannot afford }\end{array}$ \\
\hline Resource Constraint & G42 & $\begin{array}{l}\text { Not quite easy maintaining the field agents and associated } \\
\text { cost }\end{array}$ \\
\hline $\begin{array}{l}\text { Resource Constr. Market } \\
\text { Expansion }\end{array}$ & G43 & $\begin{array}{l}\text { Inability to cope with the volume of material submission } \\
\text { required (Bids) to prospect into new market is also limited by } \\
\text { our resources. Most of them will need almost a man-day to } \\
\text { submit. }\end{array}$ \\
\hline Resource Constraint & G44 & $\begin{array}{l}\text { At those points we ask ourselves: Can we really afford this as } \\
\text { a small organisation? }\end{array}$ \\
\hline Resource Base & G51 & $\begin{array}{l}\text { Since there may not be education in that region for a while and } \\
\text { we cannot afford to provide the training, we have gone the } \\
\text { route of indirect }\end{array}$ \\
\hline Ground Support & G59 & Bigger company can afford local ground support \\
\hline Finance Constraint & G63 & $\begin{array}{l}\text { The government appears to have place a ceiling on what they } \\
\text { are willing to finance and guarantee }\end{array}$ \\
\hline Payment instrument & G69 & $\begin{array}{l}\text { Securing letter of credit was a serious issue and that delayed } \\
\text { us for quite a while }\end{array}$ \\
\hline Org. Size & 31 & $\begin{array}{l}\text { Canada is full of small size organizations "bunch of small } \\
\text { companies. You have very narrow market disciplines and they } \\
\text { normally don't have the resources to go after the world" }\end{array}$ \\
\hline
\end{tabular}




\section{Appendix K : Market Environment}

\begin{tabular}{|c|c|c|}
\hline Code & Code & Notes and Quotes from transcribed data \\
\hline Bureaucracy & A18 & $\begin{array}{l}\text { Obviously if you don't get paid, there are fairly clearly } \\
\text { defined way of seeking to seek that payment right? }\end{array}$ \\
\hline Risk & A19 & $\begin{array}{l}\text { If you don't get paid in foreign market, I don't know } \\
\text { what happens .. What starts happening.. right? }\end{array}$ \\
\hline Trust & A22 & $\begin{array}{l}\text { That's the overriding issue. Its trust, trust on the customer } \\
\text { base }\end{array}$ \\
\hline Trust & A25 & $\begin{array}{l}\text { then screened customer.. screened customer that you can } \\
\text { trust }\end{array}$ \\
\hline Process Delay & B11 & $\begin{array}{l}\text { You have to be prepared, I think, to travel there, to support } \\
\text { the country and to go through a fairly long time without } \\
\text { revenue. }\end{array}$ \\
\hline Local regulation & B34 & $\begin{array}{l}\text { the reasons that India is one of the first countries we are } \\
\text { targeting is because they are passing legislation that will } \\
\text { change the way the telecommunications operators will have } \\
\text { to operate their towers }\end{array}$ \\
\hline Favourable legislation & B36 & $\begin{array}{l}\text { So obviously that legislation been passed has been a huge } \\
\text { help to us, and to make it even better, the government in } \\
\text { India is reducing the tax on renewable energy systems that } \\
\text { are been imported into India specifically for } \\
\text { telecommunications }\end{array}$ \\
\hline $\begin{array}{l}\text { Favourable Home } \\
\text { Govt }\end{array}$ & B37 & $\begin{array}{l}\text { EDC), will provide funding to the companies in these } \\
\text { developing nations specifically so they can buy our product. }\end{array}$ \\
\hline Govt. Funding & B38 & $\begin{array}{l}\text { the Canadian government would loan the company in Chile } \\
\text { the money which then that company would in turn, then buy } \\
\text { the batteries from us. }\end{array}$ \\
\hline Unstable Govt. & B43 & $\begin{array}{l}\text { I do have concern with government, and again, that's } \\
\text { where i need to trust the company that we hire in those } \\
\text { countries, I need to trust them to understand the risk, to tell } \\
\text { me about the risk and help mitigate the risk }\end{array}$ \\
\hline B memo 8 & & $\begin{array}{l}\text { Unstable govermment only translate to risk. If risk can be } \\
\text { managed, this coy. Is ready to proceed. }\end{array}$ \\
\hline Protocol/Procedure & C13 & $\begin{array}{l}\text { Power generation requires lots of permit and consequently } \\
\text { not many are willing to persevere }\end{array}$ \\
\hline Conditional Direct & C17 & Hire a local Engineer to provide for necessary permit \\
\hline $\begin{array}{l}\text { Regulated } \\
\text { environment }\end{array}$ & C22 & $\begin{array}{l}\text { Compels the use of local market link, not necessarily an } \\
\text { agent }\end{array}$ \\
\hline Developed Market & F3 & Market potential are mainly in the developed economy \\
\hline
\end{tabular}




\section{Appendix K : Market Environment (Contd.)}

\begin{tabular}{|c|c|c|}
\hline Code & Code & Notes and Quotes from transcribed data \\
\hline New Technology & F11 & $\begin{array}{l}\text { It is a relatively new Tech as such market must } \\
\text { be well developed to support the project }\end{array}$ \\
\hline G memo 11 & & $\begin{array}{l}\text { Issuance of Letter of Credit is target market nisk } \\
\text { perception dependent. This eventually affects choice } \\
\text { of directindirect }\end{array}$ \\
\hline Mgt. Risk Factor & G26 & $\begin{array}{l}\text { Management risk tolerance determines the approach } \\
\text { to (perceived) risk laden market }\end{array}$ \\
\hline Organisational Risk Policy & G27 & $\begin{array}{l}\text { Organisational risk policy determines approach to } \\
\text { market laden with risk }\end{array}$ \\
\hline Insurable Market & G29 & $\begin{array}{l}\text { Volatile market pose challenges to financial and } \\
\text { insurance institution and that present a wall of } \\
\text { resistance to easy access to the market. Which to a } \\
\text { large extent discourages the small players }\end{array}$ \\
\hline Confidence Perception & G33 & $\begin{array}{l}\text { The level of comfort we have with this lead } \\
\text { contractor is satisfactory to our Coy. Hence the } \\
\text { decision to go with them }\end{array}$ \\
\hline Customer Risk & G45 & $\begin{array}{l}\text { Does the customer have the capacity to issue } \\
\text { the project as promised? }\end{array}$ \\
\hline Cost Risk & G54 & $\begin{array}{l}\text { If anything thus go wrond, what is the cost to us and } \\
\text { its associated risks }\end{array}$ \\
\hline Finance Constraints & G74 & $\begin{array}{l}\text { Instability in govemment leads to high level of } \\
\text { risk perception and consequently restrain in the } \\
\text { release of funds }\end{array}$ \\
\hline
\end{tabular}




\section{Appendix L : Absorptive Capacity}

\begin{tabular}{|c|c|c|}
\hline Code & Code & Notes and Quotes from transcribed data \\
\hline Risk & A19 & $\begin{array}{l}\text { If you don't get paid in foreign market, I don't know } \\
\text { what happens .. What starts happening.. right? }\end{array}$ \\
\hline Local Support & A34 & $\begin{array}{l}\text { Caribbean areas and in latin America as well, one thing is that } \\
\text { they have a lot of these labour and is relatively cheap }\end{array}$ \\
\hline Absorptive Capacity & A36 & $\begin{array}{l}\text { it's a simple system, it's easy, the training can be very } \\
\text { easy }\end{array}$ \\
\hline Average absorption & B19 & $\begin{array}{l}\text { we don't have to do very much training on our batteries } \\
\text { itself }\end{array}$ \\
\hline Education & B22 & we are dealing with people who have good education \\
\hline Local presence & B33 & $\begin{array}{l}\text { We have located a company that we think we will be very } \\
\text { happy with. }\end{array}$ \\
\hline Tech Absorption & C14 & $\begin{array}{l}\text { Capacity to understand and operate technology is of } \\
\text { concern }\end{array}$ \\
\hline Incompatible//ndirect & C15 & $\begin{array}{l}\text { One time indirect approach failed because third part have } \\
\text { little or no knowledge of Technology }\end{array}$ \\
\hline Education & E9 & $\begin{array}{l}\text { if we have that entrepreneur who gains knowledge and } \\
\text { skill in science systems or have had interact with us for } \\
\text { our support }\end{array}$ \\
\hline Education & E19 & $\begin{array}{l}\text { have to speak English, or they are not going to be } \\
\text { responding. . . . They have to be computer literate. }\end{array}$ \\
\hline Absorptive Capacity & E25 & $\begin{array}{l}\text { But those are remarkable dificult concepts to get across } \\
\text { when you don't know the literacy of the recipient }\end{array}$ \\
\hline Absorptive Capacity & F9 & Is the target market ready for the new technology? \\
\hline Local Adaptation & F10 & $\begin{array}{l}\text { Is the local market ready for the major shift from current } \\
\text { practice of land fill to recycling and energy generation }\end{array}$ \\
\hline Absorptive Capacity & F20 & $\begin{array}{l}\text { Developing nations are obviously not ready for this } \\
\text { product. They are not ready at this time }\end{array}$ \\
\hline Skill Development & F25 & $\begin{array}{l}\text { We train local employees to operate plant: Technology } \\
\text { absorptive capacity is essential for market to qualify }\end{array}$ \\
\hline Absorptive Ability & F31 & $\begin{array}{l}\text { Coy team goes to target to train personal in the target } \\
\text { market ahead of take off. }\end{array}$ \\
\hline Low Tech Absorption & G10 & $\begin{array}{l}\text { Low skilled and averagely educated target market } \\
\text { operators defines direct or indirect approach. It may } \\
\text { sometimes require the use of larger companies that has } \\
\text { its presence in the target market to provide necessary } \\
\text { trainings }\end{array}$ \\
\hline Gmemo 2 & & $\begin{array}{l}\text { Uniqueness of product results into large market in the } \\
\text { developing economy where tech absorptive capacity is } \\
\text { relatively low }\end{array}$ \\
\hline
\end{tabular}




\section{Appendix L : Absorptive Capacity (Contd.)}

\begin{tabular}{|c|c|c|}
\hline Code & Code & Notes and Quotes from transcribed data \\
\hline $\begin{array}{l}\text { Technology } \\
\text { Absorption }\end{array}$ & G46 & $\begin{array}{l}\text { Is the customer able to directly absorb our technology? } \\
\text { What level of technology is acceptable to the market, and } \\
\text { do we have it? Or are we better of going to the market with } \\
\text { a bigger organisation that has training facility in place. }\end{array}$ \\
\hline Simple Tech & G47 & $\begin{array}{l}\text { The locals could fix the problems because Tech was quite } \\
\text { simple }\end{array}$ \\
\hline $\begin{array}{l}\text { Technology } \\
\text { Absorption }\end{array}$ & G48 & The level of tech professionals were quite high \\
\hline $\begin{array}{l}\text { Technology } \\
\text { Capability }\end{array}$ & G49 & $\begin{array}{l}\text { When the market has high local capability, we SSEs can } \\
\text { readily identify with their market. }\end{array}$ \\
\hline Level of Education & G62 & $\begin{array}{l}\text { Level of education in the target market is of high } \\
\text { consideration for direct market access }\end{array}$ \\
\hline G memo 24 & & $\begin{array}{l}\text { Client's absorptive capacity is in direct correlation with } \\
\text { choice of direct or indirect transfer. It influences the } \\
\text { necessary ground support required in this industry } \\
\text { technology requirement. }\end{array}$ \\
\hline No Capacity & G50 & $\begin{array}{l}\text { In our current market (approached indirectly), the people } \\
\text { has no capacity to absort anything. The war has torn the } \\
\text { whole place apart. No education or learning opportunity } \\
\end{array}$ \\
\hline G memo 25 & & $\begin{array}{l}\text { Lack of after sales support partially influenced the choice of } \\
\text { indirect to Angola: Where there is no formal education, } \\
\text { direct Tech transfer can be very challenging in the face of } \\
\text { SSE scarce resources. }\end{array}$ \\
\hline Ground Support & G61 & $\begin{array}{l}\text { Direct access to market is easier Where Target market } \\
\text { professionals are able to provide ground support }\end{array}$ \\
\hline Market Agents & G67 & A local agent invited us into the market \\
\hline Functional Agent & G71 & Ground agent was useful during renegotiation exercise \\
\hline Competence & H6 & $\begin{array}{l}\text { Technology requires skills to implement the advances in } \\
\text { computer application to the existing technology }\end{array}$ \\
\hline Product Plus & H16 & Tech source in-house training condition for accepting tech \\
\hline Representatives & H39 & $\begin{array}{l}\text { Users require local presence (Note this is particularly for } \\
\text { marketing, not quite for tech transfer?? }\end{array}$ \\
\hline Obvious Presence & $\mathrm{H} 40$ & Need a local number to call when there is problem \\
\hline Tech. Gap & $\mathrm{H} 42$ & $\begin{array}{l}\text { Tech gap between end user and supplier hinder transfer (. . } \\
\text {. . To India) }\end{array}$ \\
\hline H memo 37 & & Local absorptive capacity determines direct or indirect \\
\hline Tech. Absorption & H43 & $\begin{array}{l}\text { Readiness of end users to accept technology (found to } \\
\text { hinder transfer)...go indirect to facilitate learning through } \\
\text { locally available organization??? }\end{array}$ \\
\hline
\end{tabular}




\section{Appendix M : Type of Technology}

\begin{tabular}{|c|c|c|}
\hline Code & Code & Notes and Quotes from transcribed data \\
\hline Simple Tech & A35 & it's a simple system, it's easy, the training can be very easy \\
\hline Simple Tech & A37 & $\begin{array}{l}\text { but to be honest with you, we've trained people within half } \\
\text { a day to be able to do the work }\end{array}$ \\
\hline Simple Tech & B18 & it should require less training than other battery systems \\
\hline Incompatible/Indirect & C15 & $\begin{array}{l}\text { One time indirect approach failed because third party have } \\
\text { little or no knowledge of Technology }\end{array}$ \\
\hline C memo 1 & & $\begin{array}{l}\text { The knowledge of the product is key determinant in choice of } \\
\text { direct or indirect. Indirect with lack in knowledge of product may } \\
\text { always lead transfer failure! }\end{array}$ \\
\hline Specialized Tech & C16 & $\begin{array}{l}\text { Knowledge of Tech not quite prevalent in the market and } \\
\text { this led to indirect link failure }\end{array}$ \\
\hline C memo 8 & & $\begin{array}{l}\text { So pretty much it is the complexity involve and the level of } \\
\text { your technology that determines the method that you } \\
\text { engage i.e direct or indirect }\end{array}$ \\
\hline Technology Base & $\mathrm{C} 25$ & Our product is highly technical \\
\hline Prod. Deter. Mrkt & F4 & $\begin{array}{l}\text { The nature of this product determines its market. The } \\
\text { process is of high tech which can only be supported in the } \\
\text { developed economy }\end{array}$ \\
\hline New Technology & F11 & $\begin{array}{l}\text { It is a relatively new Tech as such market must be well } \\
\text { developed to support the project }\end{array}$ \\
\hline New Technology & F27 & $\begin{array}{l}\text { Access to the market have met with the challenge of it being a } \\
\text { new technology }\end{array}$ \\
\hline New Tech Risks & F28 & $\begin{array}{l}\text { There is always a risk of the first timer accepting new tech. } \\
\text { Hence our challenge of penetrating the market }\end{array}$ \\
\hline New Tech & F29 & $\begin{array}{l}\text { No community wants to be the first, Nobody wants to be } \\
\text { the "guinea pig" }\end{array}$ \\
\hline Established Tech & F30 & $\begin{array}{l}\text { Tested technology receive prompt acceptance unlike the } \\
\text { new Technology as in this case }\end{array}$ \\
\hline Unique Tech & G3 & $\begin{array}{l}\text { Differentiated application of technology not available on } \\
\text { mass production line }\end{array}$ \\
\hline G memo 2 & & $\begin{array}{l}\text { Uniqueness of product results into large market in the } \\
\text { developing economy where tech absorptive capacity is } \\
\text { relatively low }\end{array}$ \\
\hline $\begin{array}{l}\text { Prod. Base Sales } \\
\text { Point }\end{array}$ & G11 & $\begin{array}{l}\text { Unique product influence the willingness of MNE to take } \\
\text { product to the market }\end{array}$ \\
\hline
\end{tabular}




\section{Appendix M: Type of Technology Contd.)}

\begin{tabular}{|c|c|c|}
\hline Code & Code & Notes and Quotes from transcribed data \\
\hline Unique Tech & $\mathrm{H} 21$ & $\begin{array}{l}\text { We go indirect (through MTNe) when the multinational do not } \\
\text { have our type of service in their product line }\end{array}$ \\
\hline Mix Mode & $\mathrm{H} 22$ & $\begin{array}{l}\text { This a conditional direct or indirect: MTN have no parallel } \\
\text { service; we supply through them or direct to client at their } \\
\text { influence/influence }\end{array}$ \\
\hline Non unique Tech & $\mathrm{H} 23$ & $\begin{array}{l}\text { MTNe carries competitive product line with ours: we go direct } \\
\text { but face competition! }\end{array}$ \\
\hline H memo 15 & & $\begin{array}{l}\text { Direct/direct becomes a function of unique technology not } \\
\text { carried by MNE }\end{array}$ \\
\hline H memo 16 & & $\begin{array}{l}\text { Where brand name is not known, intermediary service provider will be } \\
\text { readily embraced? }\end{array}$ \\
\hline Tech Type & $\mathrm{H} 34$ & $\begin{array}{l}\text { Not a standalone type of technology. It thus require an } \\
\text { umbrella organization to transfer technology }\end{array}$ \\
\hline H memo 32 & & $\begin{array}{l}\text { Indirect transfer influenced by the nature of the service } \\
\text { provided (and the industry). }\end{array}$ \\
\hline Unique Tech & $\mathrm{H} 38$ & We always have to go through somebody else...... \\
\hline Tech. Gap & H42 & $\begin{array}{l}\text { Tech gap between end user and supplier hinder transfer (. . . . } \\
\text { To India) }\end{array}$ \\
\hline
\end{tabular}

